Prepared as part of the

National Water-Quality Assessment Program

Source Water-Quality Assessment

\title{
Anthropogenic Organic Compounds in Source Water of Nine Community Water Systems that Withdraw from Streams, 2002-05
}

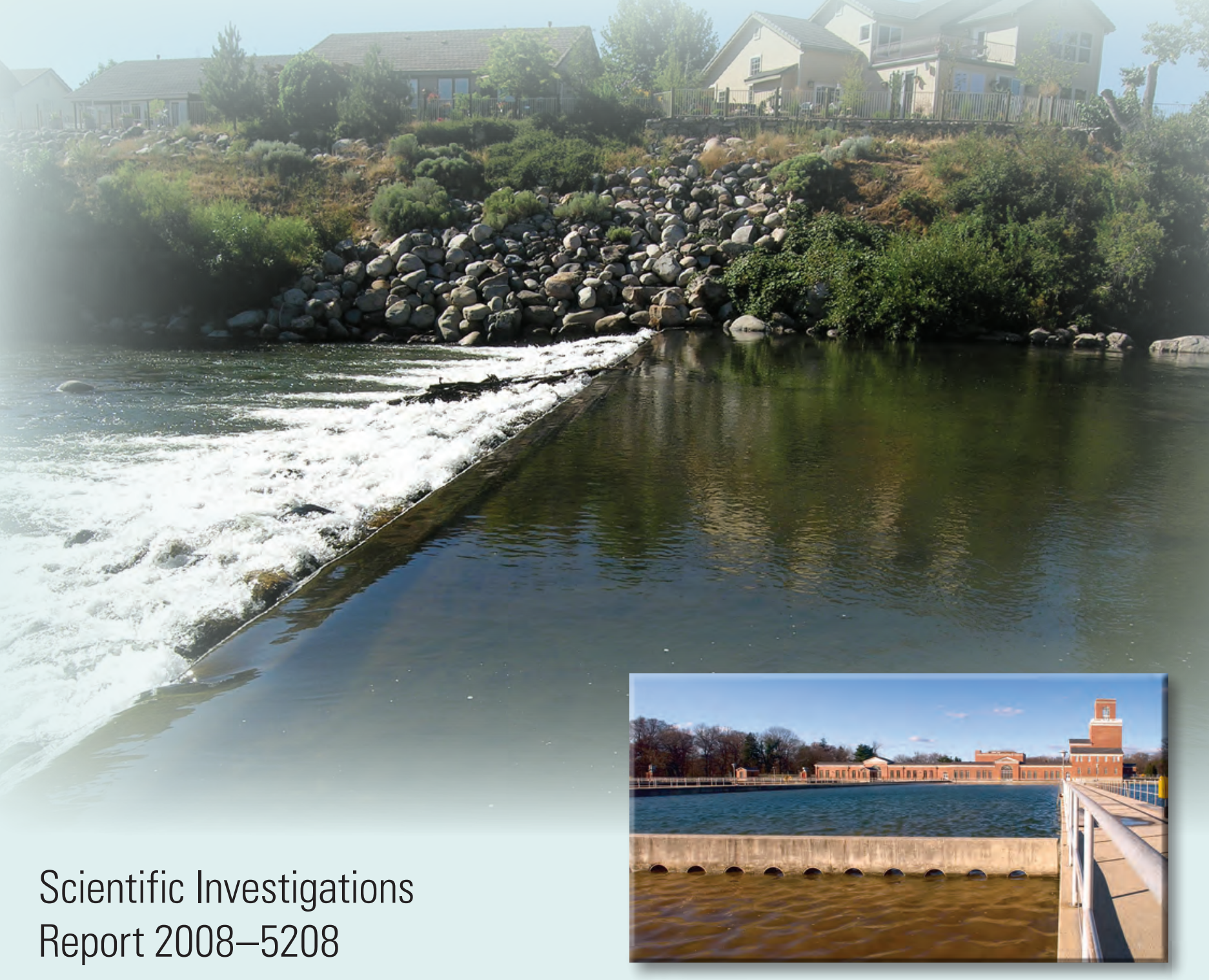

U.S. Department of the Interior U.S. Geological Survey 
Front cover photographs: The Truckee River in Nevada (upper photograph by Gregory Delzer, U.S. Geological Survey) and the Washington Aqueduct on the Potomac River near Washington, D.C. (lower photograph by Eric Vance, U.S. Environmental Protection Agency).

Back cover photograph: The Washington Aqueduct (photograph courtesy of the Washington Aqueduct). 


\section{Anthropogenic Organic Compounds in Source Water of Nine Community Water Systems that Withdraw from Streams, 2002-05}

By James A. Kingsbury, Gregory C. Delzer, and Jessica A. Hopple

Prepared as part of the

National Water-Quality Assessment Program

Source Water-Quality Assessment

Scientific Investigations Report 2008-5208 


\title{
U.S. Department of the Interior DIRK KEMPTHORNE, Secretary
}

\author{
U.S. Geological Survey \\ Mark D. Myers, Director
}

U.S. Geological Survey, Reston, Virginia: 2008

This and other USGS information products are available at http://store.usgs.gov/
U.S. Geological Survey
Box 25286, Denver Federal Center
Denver, CO 80225
To learn about the USGS and its information products visit http://www.usgs.gov/
1-888-ASK-USGS

Any use of trade, product, or firm names is for descriptive purposes only and does not imply endorsement by the U.S. Government.

Although this report is in the public domain, permission must be secured from the individual copyright owners to reproduce any copyrighted materials contained within this report.

Suggested citation:

Kingsbury, J.A., Delzer, G.C., and Hopple, J.A., 2008, Anthropogenic organic compounds in source water of nine community water systems that withdraw from streams, 2002-05: U.S. Geological Survey Scientific Investigations Report 2008-5208, 66 p. 


\section{FOREWORD}

The U.S. Geological Survey (USGS) is committed to providing the Nation with credible scientific information that helps to enhance and protect the overall quality of life and that facilitates effective management of water, biological, energy, and mineral resources (http://www. usgs.gov/). Information on the Nation's water resources is critical to ensuring long-term availability of water that is safe for drinking and recreation and is suitable for industry, irrigation, and fish and wildlife. Population growth and increasing demands for water make the availability of that water, now measured in terms of quantity and quality, even more essential to the long-term sustainability of our communities and ecosystems.

The USGS implemented the National Water-Quality Assessment (NAWQA) Program in 1991 to support national, regional, State, and local information needs and decisions related to water-quality management and policy (http://water.usgs.gov/nawqa). The NAWQA Program is designed to answer: What is the condition of our Nation's streams and ground water? How are conditions changing over time? How do natural features and human activities affect the quality of streams and ground water, and where are those effects most pronounced? By combining information on water chemistry, physical characteristics, stream habitat, and aquatic life, the NAWQA Program aims to provide science-based insights for current and emerging water issues and priorities. From 1991-2001, the NAWQA Program completed interdisciplinary assessments and established a baseline understanding of water-quality conditions in 51 of the Nation's river basins and aquifers, referred to as Study Units (http://water.usgs.gov/nawqa/studyu.htm).

Multiple national and regional assessments are ongoing in the second decade (2001-2012) of the NAWQA Program as 42 of the 51 Study Units are reassessed. These assessments extend the findings in the Study Units by determining status and trends at sites that have been consistently monitored for more than a decade, and filling critical gaps in characterizing the quality of surface water and ground water. For example, increased emphasis has been placed on assessing the quality of source water and finished water associated with many of the Nation's largest community water systems. During the second decade, NAWQA is addressing five national priority topics that build an understanding of how natural features and human activities affect water quality, and establish links between sources of contaminants, the transport of those contaminants through the hydrologic system, and the potential effects of contaminants on humans and aquatic ecosystems. Included are topics on the fate of agricultural chemicals, effects of urbanization on stream ecosystems, bioaccumulation of mercury in stream ecosystems, effects of nutrient enrichment on aquatic ecosystems, and transport of contaminants to public-supply wells. These topical studies are conducted in those Study Units most affected by these issues; they comprise a set of multi-Study-Unit designs for systematic national assessment. In addition, national syntheses of information on pesticides, volatile organic compounds (VOCs), nutrients, selected trace elements, and aquatic ecology are continuing.

The USGS aims to disseminate credible, timely, and relevant science information to address practical and effective water-resource management and strategies that protect and restore water quality. We hope this NAWQA publication will provide you with insights and information to meet your needs, and will foster increased citizen awareness and involvement in the protection and restoration of our Nation's waters.

The USGS recognizes that a national assessment by a single program cannot address all waterresource issues of interest. External coordination at all levels is critical for cost-effective management, regulation, and conservation of our Nation's water resources. The NAWQA Program, therefore, depends on advice and information from other agencies-Federal, State, regional, interstate, Tribal, and local—as well as nongovernmental organizations, industry, academia, and other stakeholder groups. Your assistance and suggestions are greatly appreciated.

Matthew C. Larsen

Associate Director for Water 


\section{Contents}

Abstract

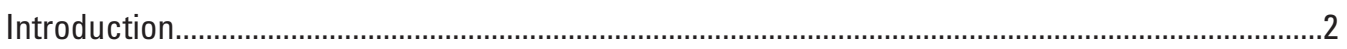

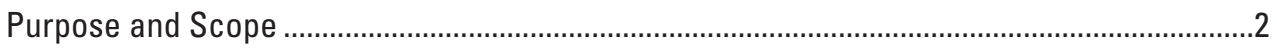

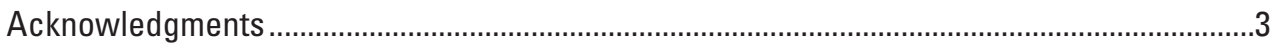

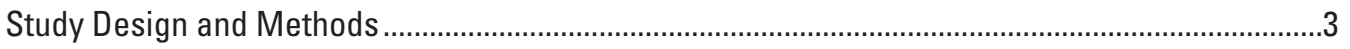

Characteristics of Stream Sites and Community Water Systems ...........................................

Compounds Monitored ..................................................................................................

Sample Collection and Protocols ........................................................................................

Analytical Methods............................................................................................................

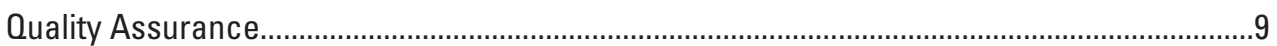

Human-Health Benchmarks used in a Screening-Level Assessment.....................................11

Annual Mean Concentration Calculations ………………...............................................12

Anthropogenic Organic Compounds in Source Water Sampled During 2002-04 .........................12

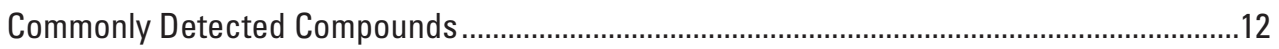

Comparison to Human-Health Benchmarks........................................................................19

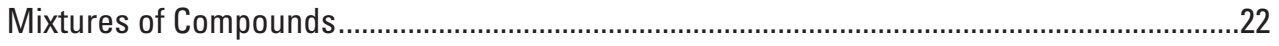

Factors that May Affect Source-Water Quality .....................................................................2

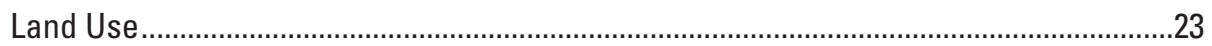

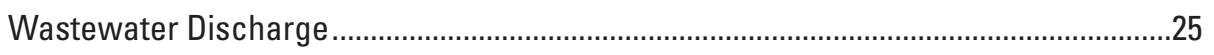

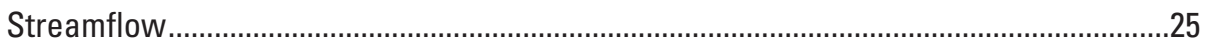

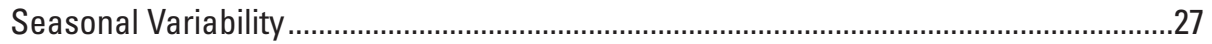

Comparisons of Selected Organic Compounds in Source Water and Finished Water

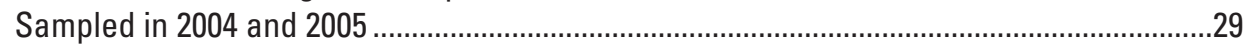

Commonly Detected Compounds ..........................................................................................30

Compounds Detected More Commonly in Source Water than in Finished Water .........30

Compounds Detected More Commonly in Finished Water than in Source Water .........32

Changes in Concentration .................................................................................................

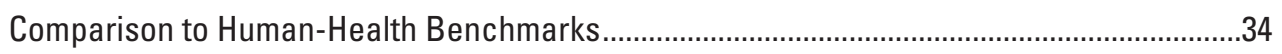

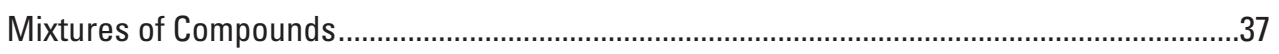

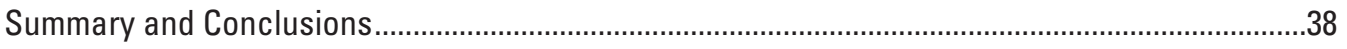

References

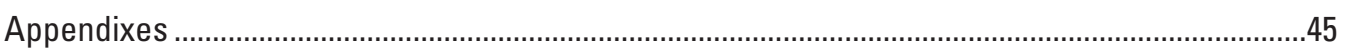

Appendix 1. Summary statistics and human-health benchmarks for anthropogenic organic compounds analyzed in source-water samples collected during the first phase of sampling, October 2002-March 2004 ...................................................46

Appendix 2. Summary statistics and human-health benchmarks for anthropogenic organic compounds detected in source- and finished-water samples collected during the second phase of sampling, June 2004-August 2005 


\section{Figures}

1. Map showing samples were collected from nine streams and eight

community water systems throughout the United States during 2002-05

2-18. Graphs showing:

2. Forty-seven of 258 anthropogenic organic compounds were detected using no common assessment level in 10 percent or more of sourcewater samples collected at nine community water systems (CWSs) during the first phase of sampling, October 2002 through March 2004

3. The herbicides most commonly detected in source-water samples from Source Water-Quality Assessment sites collected during the first phase of sampling, October 2002-March 2004, correspond to those detected most frequently in 156 streams across the Nation sampled by the National WaterQuality Assessment Program (1992-2001)..

4. The distributions of concentrations of herbicide degradates were similar to or greater than concentrations of parent compounds in source-water samples collected from the Neuse, Potomac, and White Rivers during the first phase of sampling, 0ctober 2002-March 2004.

5. Annual mean and single-sample concentrations of regulated anthropogenic organic compounds commonly detected in source-water samples collected during the first phase of sampling, October 2002-March 2004

6. Annual mean and single-sample concentrations of unregulated anthropogenic organic compounds commonly detected in source-water samples collected during the first phase of sampling, October 2002-March 2004

7. Mixtures of two or more anthropogenic organic compounds analyzed were present in many source-water samples collected during the first phase of sampling, October 2002-March 2004

8. The median number of anthropogenic organic compounds and median total concentration of all compounds detected in source-water samples collected during the first phase of sampling, October 2002-March 2004, for each site generally increased as the sum of agricultural and urban land use in the contributing watersheds increased

9. Atrazine concentrations in source-water samples collected during the first phase of sampling, October 2002-March 2004, generally increased as the amount of agricultural land use in the contributing watersheds increased

10. Chloroform and hexahydrohexamethylcyclopentabenzopyran were detected more commonly in source-water samples from watersheds with major wastewater discharges than in samples from watersheds without major discharges during the first phase of sampling, October 2002-March 2004

11. The concentrations of selected commonly detected anthropogenic organic compounds in source-water samples collected during the first phase of sampling, October 2002-March 2004, were related to streamflow at some sites, but not at others

12. Total herbicide concentrations in source-water samples collected during the first phase of sampling, October 2002-March 2004, varied seasonally at most sites

13. Seasonal variation in atrazine and simazine concentrations differed for samples collected from the Chattahoochee and White Rivers during the first phase of sampling, October 2002-March 2004 
14. Many commonly detected anthropogenic organic compounds generally had similar detection frequencies in source- and finished-water samples collected during the second phase of sampling, June 2004-August 2005

15. Concentrations of selected anthropogenic organic compounds in samples collected during the second phase of sampling, June 2004-August 2005 . .34

16. Changes in atrazine concentrations in source water usually were reflected in the finished-water quality in samples collected at six sites during the second phase of sampling, June 2004-August 2005.

17. During the second phase of sampling, June 2004-August 2005, $A$, annual mean concentrations of commonly detected anthropogenic organic compouonds in finished-water samples were less than human-health benchmarks; and $B$, maximum concentrations in single samples from each site generally were lower than human-health benchmarks

18. About one-half of source- and finished-water samples collected during the second phase of sampling, June 2004-August 2005, contained mixtures of 14 or more compounds

\section{Tables}

1. Characteristics of community water systems and their watersheds included in Source Water-Quality Assessments, 2002-05..

2. Water-treatment steps used by the community water systems included in this study

3. Primary use groups for compounds analyzed for Source Water-Quality Assessment studies

4. Period of sample collection and number of samples at each site for both sampling phases of Source Water-Quality Assessments, 2002-05

5. Summary of compounds detected in 5 percent or more of field blanks collected for Source Water-Quality Assessment studies, 2002-05

6. Detection frequency by site for commonly detected compounds in sourcewater samples collected during the first phase of sampling, October 2002-March 2004.

7. Length of time between collection of source- and finished-water samples during the second phase of sampling, June 2004-August 2005 


\section{Conversion Factors and Datums}

\begin{tabular}{lcl}
\hline Multiply & By & To obtain \\
\hline mile $(\mathrm{mi})$ & Length & \\
\hline & 1.609 & kilometer $(\mathrm{km})$ \\
\hline square mile $\left(\mathrm{mi}^{2}\right)$ & Area & \\
\hline & 2.590 & square kilometer $\left(\mathrm{km}^{2}\right)$ \\
\hline cubic foot per second $\left(\mathrm{ft}^{3} / \mathrm{s}\right)$ & Flow rate & cubic meter per second $\left(\mathrm{m}^{3} / \mathrm{s}\right)$ \\
million gallons per day $(\mathrm{Mgal} / \mathrm{d})$ & 0.02832 & cubic meter per second $\left(\mathrm{m}^{3} / \mathrm{s}\right)$ \\
\hline
\end{tabular}

Vertical coordinate information is referenced to the North American Vertical Datum of 1988 (NAVD 88).

Horizontal coordinate information is referenced to the North American Datum of 1983 (NAD 83).

\section{Abbreviations and Acronyms used in this Report}

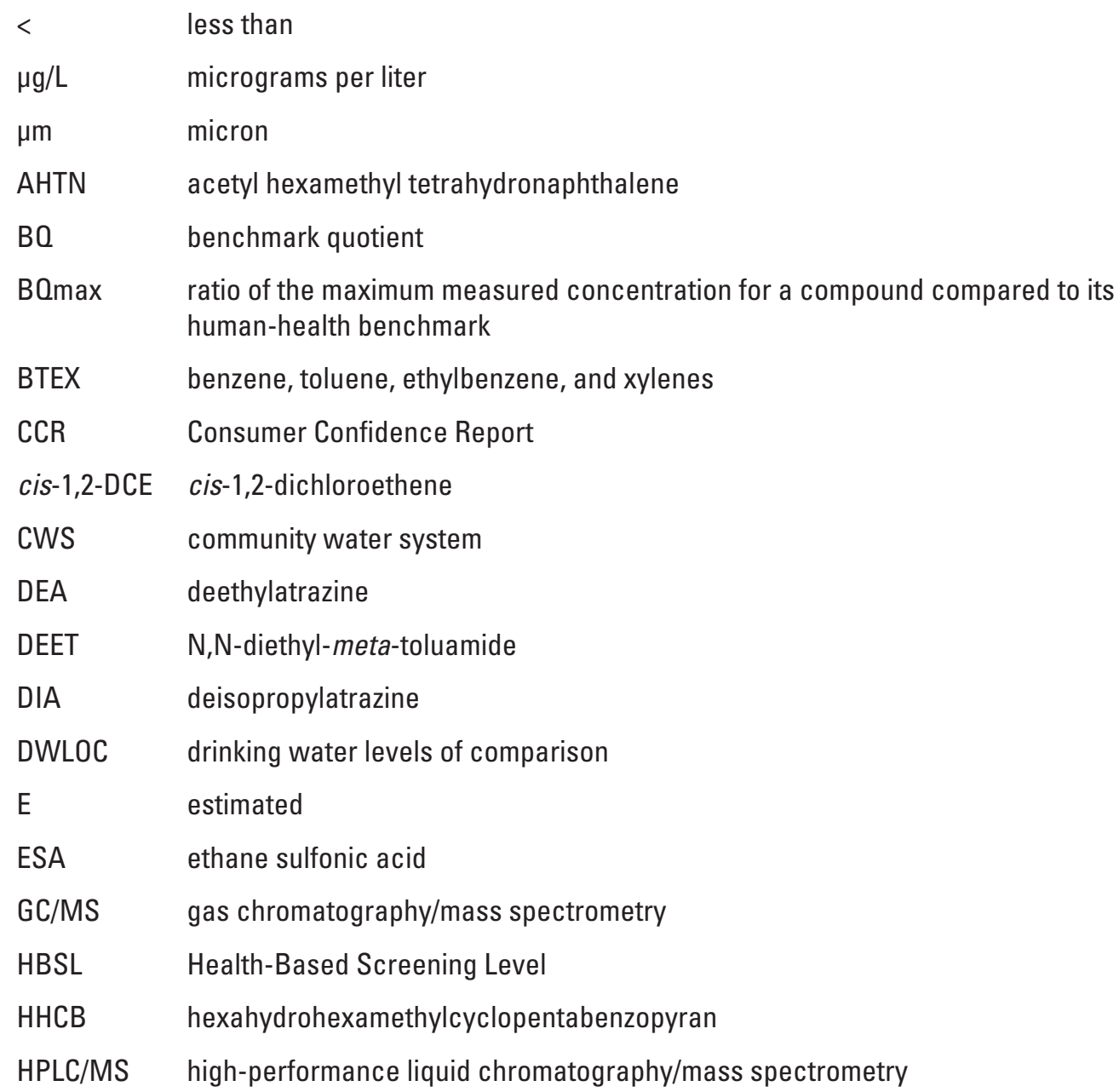




$\begin{array}{ll}\text { LRL } & \text { laboratory reporting level } \\ \text { MCL } & \text { Maximum Contaminant Level } \\ \text { MTBE } & \text { methyl tert-butyl ether } \\ \text { NAWQA } & \text { National Water-Quality Assessment } \\ \text { NWQL } & \text { National Water Quality Laboratory } \\ \text { OGRL } & \text { Organic Geochemistry Research Group Laboratory } \\ \text { PAC } & \text { powdered activated carbon } \\ \text { PAH } & \text { polynuclear aromatic hydrocarbon } \\ \text { PCE } & \text { tetrachloroethene; perchloroethene } \\ \text { PVC } & \text { polyvinyl chloride } \\ \text { OC } & \text { quality control } \\ \text { SPE } & \text { solid-phase extraction } \\ \text { SWQA } & \text { Source Water-Quality Assessment } \\ \text { TCT } & \text { total chlorotriazines } \\ \text { USEPA } & \text { U.S. Environmental Protection Agency } \\ \text { USGS } & \text { U.S. Geological Survey } \\ \text { VOC } & \text { volatile organic compound }\end{array}$

\section{Definitions}

\begin{tabular}{|c|c|}
\hline Term & Definition \\
\hline Annual Mean Concentration & $\begin{array}{l}\text { As used in this report, the annual mean concentration is the aver- } \\
\text { age concentration for all samples collected at a site over about a } \\
12 \text {-month period. }\end{array}$ \\
\hline Benchmark Quotient (BQ) & $\begin{array}{l}\text { Ratio of the concentration of a contaminant to its Maximum Con- } \\
\text { taminant Level (MCL) value for a regulated compound or to its } \\
\text { Health-Based Screening Level (HBSL) value for an unregulated } \\
\text { compound. Annual mean BQs greater than } 1 \text { identify concentrations } \\
\text { of potential human-health concern. BQs greater than } 0.1 \text { identify } \\
\text { compounds that may warrant inclusion in a low-concentration, } \\
\text { trends-monitoring program. }\end{array}$ \\
\hline BQmax & $\begin{array}{l}\text { Ratio of the maximum concentration of a contaminant to its MCL or } \\
\text { HBSL value. }\end{array}$ \\
\hline BQmean & $\begin{array}{l}\text { Ratio of the annual mean concentration of a contaminant to its MCL } \\
\text { or HBSLvalue. Annual mean concentrations were calculated using } \\
\text { all samples from a given site and using a value of one-half of the } \\
\text { laboratory reporting level for samples in which a compound was not } \\
\text { detected. }\end{array}$ \\
\hline Blended Water & $\begin{array}{l}\text { As used in this report, finished water that has been blended with one } \\
\text { or more different ground-water sources prior to treatment. Systems } \\
\text { that blend finished surface water with other surface-water sources } \\
\text { were avoided. }\end{array}$ \\
\hline
\end{tabular}




\begin{tabular}{|c|c|}
\hline Term & Definition \\
\hline $\begin{array}{l}\text { Concentration of Potential } \\
\text { Human-Health Concern }\end{array}$ & $\begin{array}{l}\text { As used in this report: (1) for a regulated compound with a U.S. } \\
\text { Environmental Protection Agency (USEPA) drinking-water stan- } \\
\text { dard, a concentration greater than the Maximum Contaminant Level; } \\
\text { and (2) for an unregulated compound, a concentration greater than } \\
\text { the Health-Based Screening Level. }\end{array}$ \\
\hline $\begin{array}{l}\text { Community Water System } \\
\text { (CWS) }\end{array}$ & $\begin{array}{l}\text { A public water system with } 15 \text { or more connections and serving } 25 \text { or } \\
\text { more year-round residents and thus is subject to USEPA and State } \\
\text { regulations enforcing the Safe Drinking Water Act. A CWS serves a } \\
\text { residential population, such as a municipality, mobile home park, or } \\
\text { nursing home. }\end{array}$ \\
\hline Drinking-Water Guideline & $\begin{array}{l}\text { As used in this report, a threshold concentration that has no regulatory } \\
\text { status, but is issued in an advisory capacity by the USEPA or State } \\
\text { agencies. }\end{array}$ \\
\hline Drinking-Water Standard & $\begin{array}{l}\text { As used in this report, a threshold concentration that is legally enforce- } \\
\text { able (such as MCLs) by the USEPA or State agencies. }\end{array}$ \\
\hline Finished Water & $\begin{array}{l}\text { Water is "finished" when it has passed through all the processes in a } \\
\text { water-treatment plant and is ready to be delivered to consumers. }\end{array}$ \\
\hline $\begin{array}{l}\text { Health-Based Screening Level } \\
\quad \text { (HBSL) }\end{array}$ & $\begin{array}{l}\text { Benchmark concentrations of contaminants in water that may be of } \\
\text { potential concern for human health, if exceeded. HBSLs are non- } \\
\text { enforceable benchmarks that were developed by the USGS in col- } \\
\text { laboration with USEPA, New Jersey Department of Environmental } \\
\text { Protection, and Oregon Health \& Science University using USEPA } \\
\text { methodologies for establishing drinking-water guidelines and the } \\
\text { most current USEPA peer-reviewed publicly available human-health } \\
\text { toxicity information. }\end{array}$ \\
\hline Human-Health Benchmarks & $\begin{array}{l}\text { As used in this report, these include USEPA MCL values and HBSL } \\
\text { values. }\end{array}$ \\
\hline $\begin{array}{l}\text { Maximum Contaminant Level } \\
\text { (MCL) }\end{array}$ & $\begin{array}{l}\text { USEPA drinking-water standard that is legally enforceable, and that } \\
\text { sets the maximum permissible level of a contaminant in water that is } \\
\text { delivered to any user of a public water system. }\end{array}$ \\
\hline Quench & $\begin{array}{l}\text { Stop a chemical reaction; in this report quench refers to the addition of } \\
\text { ascorbic acid to scavenge free chlorine in samples. }\end{array}$ \\
\hline Regulated Compound & $\begin{array}{l}\text { As used in this report, a compound for which a Federal drinking-water } \\
\text { standard has been established. }\end{array}$ \\
\hline Source Water & $\begin{array}{l}\text { Source water is the raw (ambient) water collected at a surface-water } \\
\text { intake prior to water treatment used to produce finished water. }\end{array}$ \\
\hline Unregulated Compound & $\begin{array}{l}\text { As used in this report, a compound for which no Federal drinking- } \\
\text { water standard has been established. Note that a compound that } \\
\text { is unregulated by USEPA in drinking water under the Safe Drink- } \\
\text { ing Water Act may be regulated in other contexts and under other } \\
\text { statutes. }\end{array}$ \\
\hline
\end{tabular}





\title{
Anthropogenic Organic Compounds in Source Water of Nine Community Water Systems that Withdraw Water from Streams, 2002-05
}

\author{
By James A. Kingsbury, Gregory C. Delzer, and Jessica A. Hopple
}

\section{Abstract}

Source water, herein defined as stream water collected at a water-system intake prior to water treatment, was sampled at nine community water systems, ranging in size from a system serving about 3,000 people to one that serves about 2 million people. As many as 17 source-water samples were collected at each site over about a 12-month period between 2002 and 2004 for analysis of 258 anthropogenic organic compounds. Most of these compounds are unregulated in drinking water, and the compounds analyzed include pesticides and selected pesticide degradates, gasoline hydrocarbons, personal-care and domestic-use compounds, and solvents. The laboratory analytical methods used in this study have relatively low detection levels - commonly 100 to 1,000 times lower than State and Federal standards and guidelines for protecting water quality. Detections, therefore, do not necessarily indicate a concern to human health but rather help to identify emerging issues and to track changes in occurrence and concentrations over time.

About one-half (134) of the compounds were detected at least once in source-water samples. Forty-seven compounds were detected commonly (in 10 percent or more of the samples), and six compounds (chloroform, atrazine, simazine, metolachlor, deethylatrazine, and hexahydrohexamethylcyclopentabenzopyran (HHCB) were detected in more than one-half of the samples. Chloroform was the most commonly detected compound - in every sample (year round) at five sites. Findings for chloroform and the fragrances HHCB and acetyl hexamethyl tetrahydronaphthalene (AHTN) indicate an association between occurrence and the presence of large upstream wastewater discharges in the watersheds. The herbicides atrazine, simazine, and metolachlor also were among the most commonly detected compounds. Degradates of these herbicides, as well as those of a few other commonly occurring herbicides, generally were detected at concentrations similar to or greater than concentrations of the parent compound. Samples typically contained mixtures of two or more compounds. The total number of compounds and their total concentration in samples generally increased with the amount of urban and agricultural land use in a watershed.
Annual mean concentrations of all compounds were less than human-health benchmarks. Single-sample concentrations of anthropogenic organic compounds in source water generally were less than 0.1 microgram per liter and less than established human-health benchmarks. Human-health benchmarks used for comparison were U.S. Environmental Protection Agency (USEPA) Maximum Contaminant Levels (MCLs) for regulated compounds and U.S. Geological Survey HealthBased Screening Levels for unregulated compounds. About one-half of all detected compounds do not have human-health benchmarks or adequate toxicity information for evaluating results in a human-health context.

During a second sampling phase (2004-05), source water and finished water (water that has passed through all the treatment processes but prior to distribution) were sampled at eight of the nine community water systems. Water-treatment processes differ among the systems. Specifically, treatment at five of the systems is conventional, typically including steps of coagulation, flocculation, sedimentation, filtration, and disinfection. One water system uses slow sand filtration and disinfection, a second system uses ozone as a preliminary treatment step to conventional treatment, and a third system is a direct filtration treatment plant that uses many of the steps employed in conventional treatment. Most of these treatment steps are not designed specifically to remove the compounds monitored in this study.

About two-thirds of the compounds detected commonly in source water were detected at similar frequencies in finished water. Although the water-treatment steps differ somewhat among the eight water systems, the amount of change in concentration of the compounds from source- to finished-water samples generally did not differ systematically at one or among the water systems for compounds with similar detection frequencies in source and finished water. Additionally, changes in concentration over time in source water of some compounds, for example seasonal changes in atrazine concentrations, usually were reflected in the associated finished water.

Some compounds detected in source water were removed or transformed during treatment and, therefore, were not detected in finished water. These included aromatic 
hydrocarbons with one or more methyl groups, 3,4-dichloroaniline (diuron degradate), the organophosphate insecticides (diazinon and malathion), and fipronil. On the basis of results for matrix spikes, decreases in concentration of these compounds or nondetections in finished water likely were due to degradation or transformation as a result of chlorine disinfection.

The annual mean concentration of all compounds detected in finished water were less than established humanhealth benchmarks, and concentrations of most compounds were several orders of magnitude less than human-health benchmarks. With the exception of one detection of atrazine at one site, maximum measured concentrations of all commonly detected compounds in finished water were less than established human-health benchmarks. The annual mean concentration of atrazine at this site was 0.72 microgram per liter, which is less than the MCL of 3 micrograms per liter. Most source- and finished-water samples contained mixtures of 2 or more compounds, and more than one-half of both sourceand finished-water samples contained mixtures of 14 or more compounds. Degradates of commonly detected herbicides often were present at a concentration similar to or greater than of that the parent compound in both source and finished water and contributed to the number of compounds detected in mixtures.

\section{Introduction}

The occurrence of anthropogenic organic compounds in the surface waters of the Nation has been described in a growing number of studies over the past two decades (for example, Gilliom and others, 1985, 2006; Westrick, 1990; Kolpin and others, 2002). Some of these studies have focused on ambient streams in different land-use settings, whereas others have focused on streams specifically selected because of a high probability for finding specific types of contaminants. Collectively, findings from these studies point to the need for continued monitoring and evaluation of organic compounds found in sources of drinking water, referred to as source waters, using nationally consistent analytical methods and assessment techniques.

Recent studies also have found that many organic compounds present in source waters are not removed during conventional water treatment and are still detectable in finished water (Ternes and others, 2002; Coupe and Blomquist, 2004; Stackelberg and others, 2004; Westerhoff and others, 2005; Jiang and Adams, 2006). Such findings highlight the need to characterize the occurrence of compounds not typically monitored in source waters and associated finished waters.

During 1992-2001, the U.S. Geological Survey's (USGS) National Water-Quality Assessment (NAWQA) Program assessed the quality of ambient surface- and ground-water resources in 51 major river basins and aquifer systems across the Nation (http://water.usgs.gov/nawqa/studies/study units. $h t m l$ ). Beginning in 2002, NAWQA initiated "Source WaterQuality Assessments" (SWQAs) at selected community water systems (CWSs) across the United States (Delzer and Hamilton, 2007). The long-term goal is to complete SWQAs at about $30 \mathrm{CWSs}$ that withdraw water from streams by 2012. The primary emphasis of SWQAs is to characterize the occurrence of a large number of anthropogenic organic compounds that are predominantly unregulated by the U.S. Environmental Protection Agency (USEPA) in sources of drinking water (stream water collected at a surface-water intake prior to water treatment). In addition, SWQAs are intended to provide a preliminary, broad-based assessment of selected compounds found in source water and the associated finished water (water that has passed through treatment processes but prior to distribution). These studies contribute to specific science goals and priorities of the USGS, which, in part, include assessment of environmental risk to public health and the quality of water used for drinking water, as important aspects of accounting for the freshwater resources of the Nation (U.S. Geological Survey, 2007).

The laboratory analytical methods used in SWQA studies have relatively low detection levels - commonly 100 to 1,000 times lower than State and Federal standards and guidelines for protecting water quality. Detections, therefore, do not necessarily indicate a concern to human health but rather help to identify emerging issues and to track changes in occurrence and concentrations over time. SWQAs complement existing drinking-water monitoring required by Federal, State, and local programs, which focus primarily on post-treatment compliance monitoring of contaminants regulated by USEPA in drinking water to meet requirements of the Safe Drinking Water Act. Most of the compounds analyzed in these studies are not included in other source-water and finished-water monitoring programs such as the Unregulated Contaminant Monitoring Program (U.S. Environmental Protection Agency, 2007) and the U.S. Department of Agriculture's Pesticide Data Program (U.S. Department of Agriculture, 2008).

\section{Purpose and Scope}

The primary purpose of this report is to characterize the occurrence of 258 anthropogenic organic compounds in source water of nine CWSs that withdraw water from streams, which are the first nine CWSs at which SWQAs studies have been conducted. Source-water samples were collected during 2002-04 and were analyzed for compounds that included pesticides and pesticide degradates, gasoline hydrocarbons, personal-care and domestic-use compounds, and solvents. The report describes (1) the occurrence of compounds in source water and highlights those that occur most commonly; (2) the comparison of concentrations of detected compounds to available human-health benchmarks; and (3) the characterization the number of compounds co-occurring in source water as mixtures. Although this study was not designed to 
examine specific sources and (or) factors causing and affecting the occurrence and concentrations of compounds in source waters, additional perspective is provided by highlighting general patterns and associations as appropriate, including those related to land use, wastewater discharge, streamflow, and seasonality.

A secondary purpose of this report is to provide comparisons of selected compounds in source water with their occurrence in finished water. Samples of both source and finished water were collected during 2004-05 at eight of the nine CWSs. Monitoring during this period generally used analytical methods that included compounds found to occur most commonly in source water during the 2002-04 monitoring. The sampling design and resulting comparisons were not intended to characterize treatment efficacy, but to provide a preliminary indication of the potential importance of compounds found in source water to the quality of finished water prior to distribution. In general, the types of treatment used by the CWSs that were sampled were not specifically designed to remove most of the organic compounds monitored.

A screening-level assessment of the potential significance of detected compounds in source and finished waters to human health was made, when possible, by comparing measured concentrations to human-health benchmarks. Specifically, concentrations of compounds regulated for drinking water were compared to USEPA Maximum Contaminant Levels (MCLs), and concentrations of unregulated compounds for which USEPA has published toxicity information were compared to USGS Health-Based Screening Levels (HBSLs) developed by the USGS in collaboration with USEPA, New Jersey Department of Environmental Protection, and Oregon Health \& Science University (Toccalino and others, 2003). About one-half of the compounds analyzed in this study do not have sufficient toxicity information and, therefore, do not have human-health benchmarks. The screening-level assessment provides an initial perspective on the potential importance of anthropogenic organic compounds detected. The screeninglevel assessment is not a substitute for comprehensive risk assessment, which includes many more factors, such as additional avenues of exposure.

\section{Acknowledgments}

This study could not have been completed without the cooperation of the personnel at each of the CWSs sampled, and their assistance is gratefully acknowledged. This report benefited from technical review and suggestions provided by USGS employees John Zogorski, Robert Gilliom, William Wilber, Pixie Hamilton, Michael Focazio, Donna Myers, Michael Woodside, Gary Rowe, Michael Yurewicz, Charles Crawford, and Patricia Toccalino, and USEPA employee Susan Glassmeyer. In addition, the authors would like to acknowledge Thomas Carpenter, Veronica Blette, Meredith Benedict, Thomas Grubbs, Steve Wendelken, Michael Muse,
Roy Simon, and Shanika Whitehurst (USEPA Office of Groundwater and Drinking Water); Marietta Echeverria, Elizabeth Behl, Kevin Costello, Paula Deschamp, Catherine Eiden, and Jack Housenger (USEPA Office of Pesticide Programs); Heidi Bethel and Hend Galal-Gorchev (USEPA Office of Water); Alan Roberson (American Water Works Association); Erica Brown (Association of Metropolitan Water Agencies); Darrell Osterhoudt (Association of State Drinking Water Administrators); and Paul Hendley (Syngenta Crop Protection, Inc.) for their constructive external review comments.

\section{Study Design and Methods}

CWSs selected for SWQA monitoring fit several criteria. Specifically, stream intakes were located in NAWQA Study Units where SWQA data can be compared to other NAWQA data collected during 1992 through 2001 from streams across the country. CWS intakes were located on free-flowing reaches of streams, and systems withdrawing from large reservoirs with extensive residence times (on the order of several years) were excluded. Selected CWSs ideally were singlesource systems, with little or no blending of other source waters, and CWSs that were relatively large were preferred. The type of water treatment, prior monitoring results, including those for compliance monitoring, and the type of land use in the watershed were not considerations in the selection process.

\section{Characteristics of Stream Sites and Community Water Systems}

Locations of the CWSs included in this study are shown in figure 1. Eight of the nine CWSs are categorized as "large" or "very large" water systems, defined as providing water to more than 10,000 and 100,000 people, respectively (U.S. Environmental Protection Agency, 2006a). The contributing watersheds for the nine stream sites range from about 1 to 11,500 square miles $\left(\mathrm{mi}^{2}\right)$, with most (seven) between about 480 and 2,500 $\mathrm{mi}^{2}$ (table 1). The smallest CWS is on Running Gutter Brook, serving 3,300 people, and the intake is located in a small flow-through reservoir that has a residence time of less than 2 hours.

Forested land accounts for most of the land use in seven of the nine watersheds, ranging from about 55 to 80 percent of the land area. Agricultural land, predominantly fields of row crops and pasture, makes up the largest portion of land use in the remaining two watersheds (White and Elm Fork Trinity Rivers). In the White River watershed, most of the agricultural land use ( 85 percent) is row crop, whereas in the Elm Fork Trinity watershed, pasture land accounts for about 75 percent of the agricultural land use. Urban land makes up less than 10 percent of the area of most watersheds, with the largest amount in the Neuse River watershed (14 percent). Urban land 


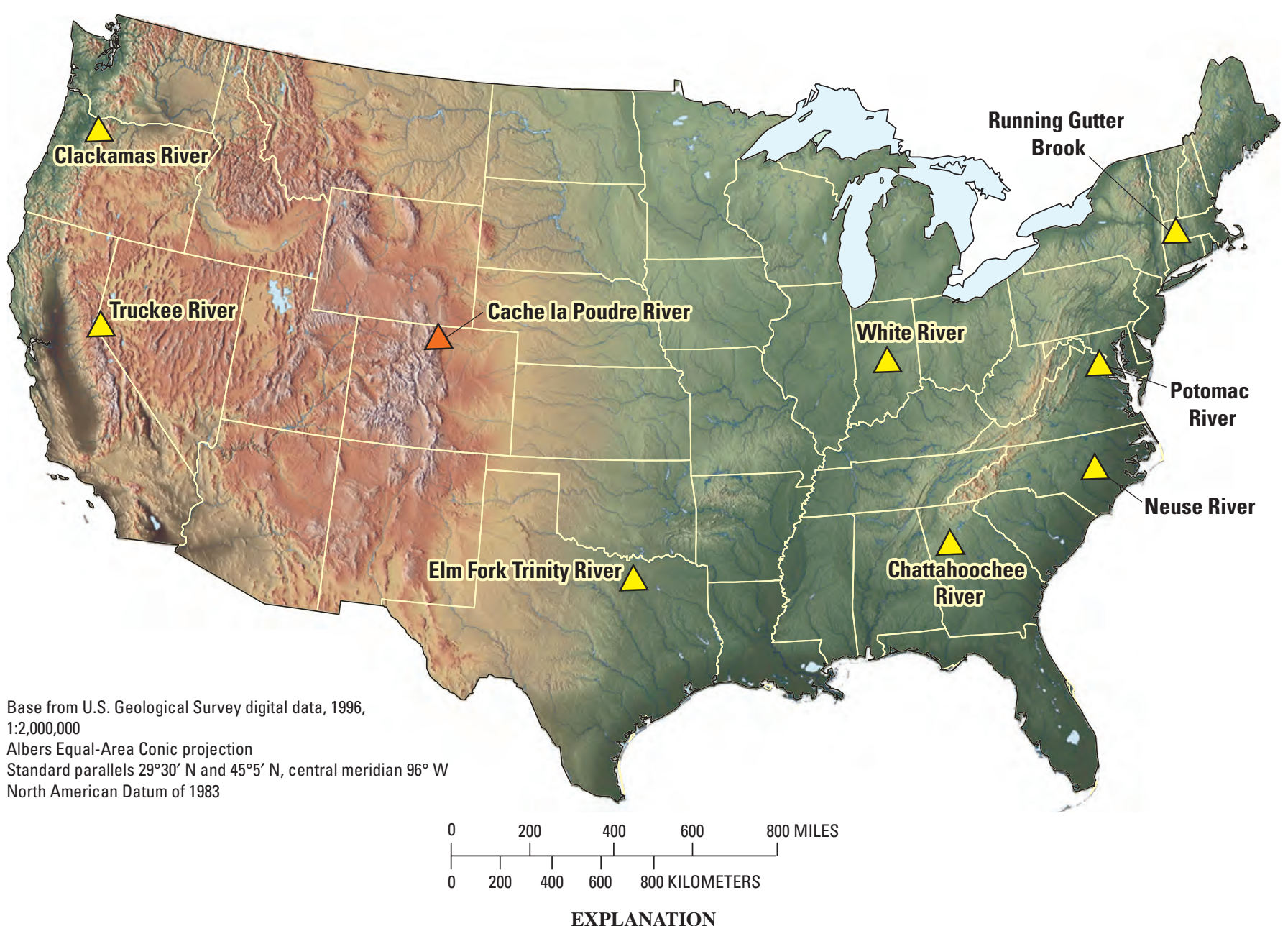

EXPLANATION

Source- and finished-water samples collected

Only source-water samples collected

Figure 1. Samples were collected from nine streams and eight community water systems throughout the United States during 2002-05.

use represents a small percentage of the land use in the watershed, but several sites are located in urban settings. "Other" land use, generally accounting for less than 30 percent of the watershed land uses, includes grassland, shrub land, and open water (table 1).

For the purposes of this study, dominant land-use categories associated with each watershed (table 1) were characterized using the NAWQA classification scheme (Gilliom and others, 2006). For example, the four streams classified as "undeveloped" drain less than 25 percent of agricultural land and less than 5 percent of urban land (Running Gutter Brook and the Cache la Poudre, Truckee, and Clackamas Rivers). Three streams classified as "mixed land use" (Chattahoochee, Neuse, and Potomac Rivers) drain mixtures, or combinations, of two or more land uses and do not meet specific criteria for individual agricultural, urban, or undeveloped land use described in Gilliom and others (2006). Two streams classified as "agricultural" (Elm Fork Trinity and White Rivers) drain more than 50 percent agricultural land and less than
5 percent of urban land. Although the White River watershed includes 8 percent urban land, in this report it was classified as agricultural rather than mixed land use because of the predominance of cultivated agricultural land use. For comparison, NAWQA land-use classifications for 1,679 public water supply intakes that withdraw water from streams in the United States indicated that 55 percent of the intakes withdraw water from streams that drain watersheds with predominantly undeveloped land, 32 percent from streams with mixed land use, 12 percent from streams with agricultural land use, and 1 percent from streams with urban land use (Gilliom and others, 2006).

The water-treatment processes used by the CWSs included in this study are largely conventional, typically consisting of the following steps: coagulation, flocculation, sedimentation, filtration, and chlorine or sodium hypochlorite disinfection (table 2). Additional treatment steps, such as chemical oxidation and $\mathrm{pH}$ adjustment are used at several of the CWSs. Powdered activated carbon (PAC) is used 
Table 1. Characteristics of community water systems and their watersheds included in Source Water-Quality Assessments, 2002-05.

[Sites are arranged top to bottom by increasing agricultural land use. CWS, community water system; Mgal/d, million gallons per day; NA, not applicable; <, less than]

\begin{tabular}{|c|c|c|c|c|c|c|c|c|c|}
\hline \multirow[b]{2}{*}{ Source Water-Quality Assessment site } & \multirow{2}{*}{$\begin{array}{l}\text { Population } \\
\text { served by } \\
\text { CWS } \\
\text { (in 2000) }\end{array}$} & \multirow{2}{*}{$\begin{array}{c}\text { Daily } \\
\text { average } \\
\text { water use } \\
\text { (Mgal/d) }\end{array}$} & \multirow{2}{*}{$\begin{array}{c}\text { Drainage } \\
\text { area upstream } \\
\text { from intake } \\
\text { (square miles) }\end{array}$} & \multirow{2}{*}{$\begin{array}{c}\text { Average daily } \\
\text { municipal } \\
\text { wastewater permitted } \\
\text { discharge for } \\
\text { major dischargers } \\
\text { (Mgal/d) }\end{array}$} & \multicolumn{5}{|c|}{ 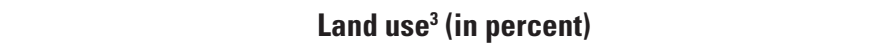 } \\
\hline & & & & & Agriculture & Urban & Forest & $\begin{array}{l}\text { Other land } \\
\text { uses }\end{array}$ & $\begin{array}{l}\text { Classification } \\
\text { (Gilliom and } \\
\text { others, 2006) }\end{array}$ \\
\hline Cache la Poudre River, Colorado & 132,000 & 27.5 & 484 & NA & $<1$ & $<1$ & 77 & 22 & Undeveloped. \\
\hline Truckee River, Nevada & 300,000 & 49 & 1,050 & NA & $<1$ & 4 & 56 & 40 & Undeveloped. \\
\hline Clackamas River, Oregon & 100,000 & 9.5 & 937 & NA & 7 & 3 & 82 & 8 & Undeveloped. \\
\hline Running Gutter Brook, Massachusetts & 3,300 & 0.24 & 1 & NA & 10 & 2 & 82 & 6 & Undeveloped. \\
\hline Chattahoochee River, Georgia & 750,000 & 65 & 1,455 & 52 & 12 & 12 & 71 & 5 & Mixed. \\
\hline Neuse River, North Carolina & 11,900 & 2.7 & 1,207 & 103 & 16 & 14 & 63 & 7 & Mixed. \\
\hline Potomac River, Maryland & $1,000,000$ & 183 & 11,464 & 150 & 34 & 4 & 60 & 2 & Mixed. \\
\hline Elm Fork Trinity River, Texas & $2,000,000$ & 154 & 2,459 & 57 & 54 & 4 & 13 & 29 & Agricultural. \\
\hline White River, Indiana & 865,000 & 15.5 & 1,168 & 61 & 86 & 8 & 4 & 2 & Agricultural. \\
\hline
\end{tabular}

${ }^{1}$ Population served data provided by community water systems.

${ }^{2}$ Major discharges are permitted to discharge $1 \mathrm{Mgal} / \mathrm{d}$ or more (U.S. Environmental Protection Agency, 2006b). Discharge is sum of daily average permitted discharge for all major wastewater-treatment plants in watershed upstream from intake.

${ }^{3}$ Land-use data are based on 1992 National Land Cover Data (Vogelmann and others, 2001). 
for seasonal taste- and odor-issues or removal of organic compounds at four of the CWSs (table 2). Treatment processes at three CWSs are notably different: the CWS on the Clackamas River is a direct filtration plant; the system at Elm Fork
Trinity River uses ozone as a preliminary treatment step to disinfect the water and to oxidize organic compounds; and the CWS on Running Gutter Brook uses slow sand filtration and disinfection (table 2).

Table 2. Water-treatment steps used by the community water systems included in this study.

[PAC, powdered activated carbon; $\mathrm{NaOCl}$, sodium hypochlorite]

\begin{tabular}{|c|c|}
\hline Source Water-Quality Assessment site & Water-treatment steps used \\
\hline Cache la Poudre River, Colorado & $\begin{array}{l}\text { (1) pre-sedimentation and screening, (2) rapid mix while coagulant (aluminum sulfate) is } \\
\text { added, (3) flocculation (polymer is added) and sedimentation, (4) solids drawn off, (5) filtra- } \\
\text { tion through anthracite and sand, (6) clear well storage, (7) disinfection/chemical addition } \\
\text { (chlorine, fluoride, lime, and chlorine dioxide), (8) storage in underground reservoirs, and } \\
\text { (9) distribution. }\end{array}$ \\
\hline Chattahoochee River, Georgia & $\begin{array}{l}\text { (1) screening, (2) coagulation (aluminum sulfate), (3) predisinfection }(\mathrm{NaOCl}) \text {, (4) flocculation } \\
\text { and sedimentation, (5) filtration through anthracite coal, sand and coarse gravel using dual } \\
\text { media filters, (6) post-chemical addition (fluoride, phosphoric acid, lime and more sodium } \\
\text { hypochlorite), (7) clear well storage, and (8) distribution. }\end{array}$ \\
\hline Clackamas River, Oregon & $\begin{array}{l}\text { (1) screening, (2) disinfection (chlorine), (3) coagulation (aluminum chlorhydrate), (4) floccula- } \\
\text { tion and sedimentation, (5) addition of filter aid (polymer), (6) filtration through anthracite } \\
\text { and sand, (7) post-disinfection/chemical addition (chlorine), soda ash, } \mathrm{pH} \text { adjustment, and } \\
\text { occasionally PAC, (8) clear well and reservoir storage, and (9) distribution. }\end{array}$ \\
\hline Elm Fork Trinity River, Texas & $\begin{array}{l}\text { (1) ozonation, (2) coagulation (ferric sulfate and polymer), (3) flocculation, (4) disinfection/ } \\
\text { chemical addition (chlorine, ammonia, fluoride, lime), (5) sedimentation, (6) filtration through } \\
\text { anthracite carbon, (7) clear well storage, and (8) distribution. }\end{array}$ \\
\hline Neuse River, North Carolina & $\begin{array}{l}\text { (1) screening, (2) pre-oxidation with potassium permanganate, (3) coagulation (aluminum } \\
\text { sulfate), (4) flocculation and sedimentation, (5) disinfection (chlorine), (6) filtration using } \\
\text { anthracite and sand, (7) disinfection (chlorine), (8) clear well storage, (9) addition of ammonia } \\
\text { and fluoride and occasionally PAC, and (10) distribution. }\end{array}$ \\
\hline Potomac River, Maryland & $\begin{array}{l}\text { (1) screening, (2) pre-sedimentation, (3) coagulation (aluminum sulfate), (4) flocculation and } \\
\text { sedimentation, (5) filtration through anthracite, sand, and coarse gravel using gravity filters, } \\
\text { (6) disinfection/chemical addition (chlorine, ammonia, fluoride, lime, and occasionally PAC), } \\
\text { and (7) distribution. }\end{array}$ \\
\hline Running Gutter Brook, Massachusetts & $\begin{array}{l}\text { (1) slow sand filtration-mixed media, and (2) chemical oxidation and disinfection (chlorine), } \\
\text { (3) occasional blending with ground water, and (4) distribution. }\end{array}$ \\
\hline Truckee River, Nevada & $\begin{array}{l}\text { (1) bar screening, (2) pre-sedimentation, (3) screening, (4) coagulation (polymers) by rapid mix- } \\
\text { ing, (5) flocculation, (6) sedimentation, (7) filtration using anthracite and sand, (8) disinfec- } \\
\text { tion (chlorine), (9) addition of soda ash, and (10) distribution. }\end{array}$ \\
\hline White River, Indiana & $\begin{array}{l}\text { (1) bar screening, (2) pretreatment, permanganate and occasionally PAC added, (3) intermit- } \\
\text { tent blending with ground water, (4) coagulation (alum), (5) flocculation and sedimentation, } \\
\text { (6) disinfection (chlorine), (7) filtration, (8) disinfection/chemical addition (chlorine, ammo- } \\
\text { nia, fluoride), (9) clear well storage, and (10) distribution. }\end{array}$ \\
\hline
\end{tabular}




\section{Compounds Monitored}

Compounds included for monitoring were selected on the basis of known or potential human-health concerns, analytical capabilities, and whether the compounds typically are not monitored in source and (or) finished water. Some compounds without known human-health concerns, such as caffeine, were included as potential indicators or surrogates for contaminants not monitored. Most of the 258 compounds monitored at all sites are not regulated in drinking water and typically are not monitored by CWSs; however, 38 compounds do have an established USEPA MCL for drinking water and are monitored in finished water by CWSs. Several inorganic compounds were considered for monitoring but were not included because they typically are monitored by CWSs and, thus would not have provided new information. Additionally, only compounds that could be analyzed using USGS approved analytical methods were considered for monitoring.

For the purposes of this report, the compounds were grouped into 13 categories on the basis of their primary use or source (table 3 and Appendix 1). The number of compounds in each of the 13 categories (hereafter termed as "use groups") varies, ranging from 3 to 82 . About one-half of the compounds analyzed are pesticides, which include three use groups - herbicides and degradates, insecticides and degradates, and fungicides. About 90 volatile organic compounds (VOCs) are categorized in six use groups, including disinfection by-products; fumigant-related compounds; gasoline hydrocarbons, oxygenates, and oxygenate degradates; organic synthesis compounds; refrigerants and propellants; and solvents. Pesticides and VOCs have been included routinely in data collection by the NAWQA Program since its inception (1991); however, most of the compounds in the remaining four use groups have not been analyzed previously by the NAWQA Program. These use groups include personalcare and domestic-use products, such as triclosan (an antibacterial agent in many hand soaps), detergent metabolites, and fragrance compounds; manufacturing additives, such as plasticizers and fire retardants; pavement- and combustionderived compounds, which are predominantly polynuclear aromatic hydrocarbons (PAHs); and plant- and animal-derived biochemicals, such as cholesterol.

\section{Sample Collection and Protocols}

Source-water samples were collected at the stream sites in two sampling phases, each lasting about a year at each site during October 2002 through March 2004 and during June 2004 through August 2005 (table 4; Carter and others, 2007). All source-water samples were collected as close as practical to the drinking-water intake or at an untreated water tap and processed following standard USGS sampling protocols (Shelton, 1994, 1997). During the first phase, source-water samples were collected about monthly (12 to 15 times) at each stream site with as many as four additional samples collected during high-flow or base-flow conditions when water-quality changes might be expected or when higher concentrations of some compounds are most likely to occur. As a result, a variety of flow conditions were sampled at most sites. Monthly samples were analyzed for 258 compounds at all sites, but at some sites, samples were analyzed for as many as 277 organic compounds (table 3 ). The number of compounds analyzed in a given sample varied for samples collected during low- and high-flow conditions, or because three additional herbicides and 16 additional degradates were analyzed in samples from the Neuse, Potomac, and White Rivers during the first sampling phase and in samples from the Elm Fork Trinity, Neuse, Potomac, and White Rivers during the second sampling phase.

During the second phase of sampling, from June 2004 through August 2005, source- and finished-water samples were collected about monthly (6 to 12 times) at eight CWSs (table 4; Carter and others, 2007). Because relatively few compounds were detected in samples from the Cache la Poudre River during the first sampling phase, this site was not sampled during the second phase. Relatively few compounds were detected in samples from the Truckee River. No samples were collected at the Truckee River for pesticide analyses, and samples for the analysis of other compounds were collected for about 6 months (table 4). The finished-water samples were collected following all of the treatment steps, prior to the water entering the distribution system. At each CWS, time was allowed between collection of source- and finishedwater samples to account for the residence time in the watertreatment plants. Finished-water samples typically contain free chlorine, which can degrade organic compounds that may be present in the samples. Therefore, a dechlorination reagent (ascorbic acid or sodium thiosulfate) and, for certain samples, $\mathrm{pH}$ buffers were added to finished-water samples during sample collection to "quench" free chlorine and stabilize samples prior to analyses (Winslow and others, 2001). Thus, results of analyses of finished-water samples are considered to be representative of the quality of water prior to distribution but not necessarily of the quality of water at the tap (delivery point). This is because of the water's additional contact time with disinfectants in the distribution system, which may allow some compounds to be transformed or degraded, whereas others, such as disinfection by-products, may continue to form in the distribution system.

\section{Analytical Methods}

Samples were analyzed using USGS approved analytical methods at the USGS National Water Quality Laboratory (NWQL) in Denver, Colo., including gas chromatography/ mass spectrometry (GC/MS) and high-performance liquid chromatography/mass spectrometry (HPLC/MS). Samples collected for VOC analyses were chilled upon collection, and one sample for the two VOC analytical methods was preserved with 1:1 hydrochloric acid. Samples for both VOC analytical 
Table 3. Primary use groups for compounds analyzed for Source Water-Quality Assessment studies.

[BTEX: benzene, toluene, ethylbenzene, and xylenes]

\begin{tabular}{|c|c|c|}
\hline $\begin{array}{l}\text { Primary use or source } \\
\text { group }\end{array}$ & Description & $\begin{array}{l}\text { Number of compounds } \\
\text { analyzed in each group }\end{array}$ \\
\hline Disinfection by-products & $\begin{array}{l}\text { Trihalomethanes, (poly)haloacetic acids and other compounds that are produced } \\
\text { from the transformation of organic compounds during the disinfection of water } \\
\text { and wastewater through chlorination, ozonation, or other chemical methods. }\end{array}$ & 4 \\
\hline $\begin{array}{l}\text { Fumigant-related com- } \\
\text { pounds }\end{array}$ & $\begin{array}{l}\text { Chemicals that may be present in commercial fumigant products, which produce } \\
\text { a gas, vapor, fumes, or smoke intended to destroy, repel, or control unwanted } \\
\text { organisms such as insects, bacteria, or rodents. These include fumigant active } \\
\text { ingredients, as well as their degradates and their manufacturing by-products. }\end{array}$ & 9 \\
\hline Fungicides & Pesticides that are used to kill unwanted fungi. & 7 \\
\hline $\begin{array}{l}\text { Gasoline hydrocarbons, } \\
\text { oxygenates, and oxygen- } \\
\text { ate degradates }\end{array}$ & $\begin{array}{l}\text { Gasoline hydrocarbons are straight, branched, and (or) cyclic organic compounds } \\
\text { that are highly volatile, contain only carbon and hydrogen atoms, and are com- } \\
\text { mon ingredients in gasoline and other petroleum products. Among these com- } \\
\text { pounds, BTEX compounds are among those present in the highest proportions } \\
\text { in gasoline. Oxygenates such as methyl tert-butyl ether (MTBE) are compounds } \\
\text { that contain only carbon, hydrogen, and oxygen atoms and are commonly added } \\
\text { to gasoline to improve the efficiency of combustion. Oxygenate degradates are } \\
\text { formed during the production, storage, release, and (or) use of gasoline oxygen- } \\
\text { ates or following their release into the environment. }\end{array}$ & 27 \\
\hline $\begin{array}{l}\text { Herbicides and herbicide } \\
\text { degradates }\end{array}$ & $\begin{array}{l}\text { Pesticides designed to kill unwanted plants (herbicides) and compounds produced } \\
\text { from the transformation of the parent herbicide following application (degra- } \\
\text { dates). }\end{array}$ & 82 \\
\hline $\begin{array}{l}\text { Insecticides and insecticide } \\
\text { degradates }\end{array}$ & $\begin{array}{l}\text { Pesticides designed to kill unwanted insects (insecticides) and compounds produced } \\
\text { from the transformation of the parent insecticide following application (degra- } \\
\text { dates). }\end{array}$ & 51 \\
\hline Manufacturing additives & $\begin{array}{l}\text { Compounds used in commercial formulations of chemical products in order to im- } \\
\text { prove the effectiveness of the product, including plasticizers (to increase the flex- } \\
\text { ibility of plastics), fire retardants, corrosion inhibitors, and pesticide adjuvants. }\end{array}$ & 7 \\
\hline $\begin{array}{l}\text { Personal-care and } \\
\text { domestic-use products }\end{array}$ & $\begin{array}{l}\text { Compounds that are present in commercial products sold for personal or residential } \\
\text { use, such as fragrances, pharmaceuticals, insect repellants, dyes, detergents, disin- } \\
\text { fectants, shampoos, and chemicals used in fire extinguishers. }\end{array}$ & 26 \\
\hline $\begin{array}{l}\text { Plant- or animal-derived } \\
\text { biochemicals }\end{array}$ & $\begin{array}{l}\text { Naturally occurring compounds that are produced by plants or animals, either } \\
\text { through direct biosynthesis or through the metabolic alteration of compounds } \\
\text { ingested or taken up from other sources. These compounds are predominantly } \\
\text { unsaturated solid alcohols of the steroid group naturally occurring in fatty tissues } \\
\text { of plants and animals and present in animal fecal material. }\end{array}$ & 5 \\
\hline $\begin{array}{l}\text { Refrigerants and } \\
\text { propellants }\end{array}$ & $\begin{array}{l}\text { Volatile compounds that are used for commercial or domestic refrigeration, as blow- } \\
\text { ing agents in the manufacture of packaging and other highly porous materials, } \\
\text { or for dispensing other substances from spray cans and other aerosol delivery } \\
\text { devices. }\end{array}$ & 3 \\
\hline Solvents & $\begin{array}{l}\text { Compounds that are used to dissolve other substances. Two of the more common } \\
\text { solvents are trichloroethene (TCE) and tetrachloroethene (perchloroethene, PCE). }\end{array}$ & 33 \\
\hline \multicolumn{2}{|l|}{ Total number of compounds } & 277 \\
\hline
\end{tabular}

${ }^{1}$ Herbicides and herbicide degradates include 3 herbicides and 16 herbicide degradates monitored at selected sites. A total of 258 compounds were monitored at all sites. 
Table 4. Period of sample collection and number of samples at each site for both sampling phases of Source Water-Quality Assessments, 2002-05.

[NA, not applicable]

\begin{tabular}{|c|c|c|c|c|}
\hline Source Water-Quality Assessment site & $\begin{array}{c}\text { Period of sample collection, } \\
\text { first phase }\end{array}$ & $\begin{array}{l}\text { Number of } \\
\text { samples }\end{array}$ & $\begin{array}{c}\text { Period of sample collection, } \\
\text { second phase }\end{array}$ & $\begin{array}{c}\text { Number of } \\
\text { samples }\end{array}$ \\
\hline Cache la Poudre River, Colorado & October 2002 - September 2003 & 17 & NA & NA \\
\hline Clackamas River, Oregon & October 2002 - September 2003 & 18 & July 2004 - May 2005 & 14 \\
\hline Elm Fork Trinity River, Texas & December 2002 - November 2003 & 17 & June 2004 - May 2005 & 15 \\
\hline Running Gutter Brook, Massachusetts & January 2003 - December 2003 & 17 & July 2004 - July 2005 & 12 \\
\hline Truckee River, Nevada & December 2002 - November 2003 & 17 & August 2004 - January 2005 & 8 \\
\hline White River, Indiana & October 2002 - September 2003 & 17 & July 2004 - June 2005 & 13 \\
\hline
\end{tabular}

methods were analyzed by purge and trap GC/MS (Connor and others, 1998; Rose and Sandstrom, 2003). Samples for analyses of pesticides and other semivolatile compounds were filtered in the field through a 0.7 -micron $(\mu \mathrm{m})$ baked glassfiber filter and chilled. These samples were extracted at the NWQL on solid-phase extraction (SPE) cartridges to concentrate the analytes from the filtered samples. SPE cartridges then were eluted with a solvent, and the extracts were analyzed by either GC/MS or HPLC/MS methods (Zaugg and others, 1995, 2002; Lindley and others, 1996; Furlong and others, 2001; Sandstrom and others, 2001; Madsen and others, 2003). At a subset of sites, an additional sample was collected for the analysis of 3 herbicides and 16 herbicide degradates. These samples were analyzed using HPLC/MS by the Organic Geochemistry Research Group Laboratory (OGRL), in Lawrence, Kansas (Lee and Strahan, 2003).

The analytical methods used at the NWQL and OGRL allow for the identification and quantification of compounds at low concentrations, in some cases as low as a few parts per trillion. Each analytical method has different ranges in sensitivity for its suite of analytes. Thus, the laboratory reporting levels (LRLs) for the compounds analyzed for SWQAs span four orders of magnitude, from about 0.003 to 6 micrograms per liter $(\mu \mathrm{g} / \mathrm{L})$, with a median of $0.06 \mu \mathrm{g} / \mathrm{L}$. Some reported concentrations are qualified with an "E" meaning estimated and indicating that the identification of the compound is reliable, but the concentration has greater uncertainty than unqualified concentrations reported for the same compound. These concentrations are estimated for one of several reasons: (1) they are less than the lowest calibration standard; (2) the sample matrix interfered with measurement of the compound; (3) surrogates added to the sample indicated poor performance during the analysis; or (4) the compound consistently has poor recoveries and concentrations are always reported as estimated.
The sensitivity of the analytical methods differs among compounds, which can affect the detection frequencies of the compounds analyzed. Those with low reporting levels likely will be detected more frequently than those with high reporting levels, given equal concentration distributions in the environment. To compare detection frequencies between compounds, a common assessment level is needed to account for the different LRLs. In this report, a common assessment level of $0.1 \mu \mathrm{g} / \mathrm{L}$ is used for this purpose. This concentration is near the median LRL of $0.06 \mu \mathrm{g} / \mathrm{L}$ for all of the compounds analyzed. Analytical results for compounds detected in source water are presented both with and without an assessment level. When concentrations of individual compounds in source- and finished-water samples are compared, no assessment level is used, and all concentrations are evaluated, including those values reported as estimated.

\section{Quality Assurance}

Similar types and numbers of quality-control (QC) samples were collected at each of the SWQA stream sites and CWSs. These QC samples, including field blanks, replicates, and matrix spikes, were evaluated together because sampling equipment and cleaning procedures, as well as sample collection and processing, were the same for all sites during both phases of sampling. Field blanks consisted of nitrogen-purged organic-free water that was processed in the field and laboratory in the same manner as environmental samples and are used to characterize the likelihood for positive bias or contamination that may affect sample analytical results. Sourcesolution blanks were analyzed for a subset of field blanks and analytical methods to assure the integrity of the water used for field blanks. Replicate samples are used to characterize the amount of variability associated with sample collection, 
processing, and analysis. Matrix spikes provide information about recoveries of organic compounds.

Field blanks collected during this study indicated that 14 of the 258 compounds potentially were affected by contamination that could bias the environmental data (table 5). Data for these compounds were removed, or results were censored to account for this potential bias as follows. Phenol and $\mathrm{N}, \mathrm{N}$-diethyl-meta-toluamide (DEET) were detected in about 50 percent or more of field blanks and were removed from the data set due to pervasive contamination in the field blanks. Although the field blank data did not identify systematic error that affected sample results for these compounds, the quality of the data for both compounds was unknown.

Three compounds were removed from the data set because of systematic contamination from the "quenching" reagents added to finished-water samples (table 5). Most field blanks collected during the second phase of sampling included the ascorbic acid and buffer that were added to finished-water samples to quench the free chlorine. Benzophenone, isophorone, and para-nonylphenol, were detected at low concentrations in most of these blanks indicating that the "quenching" reagents are a source of contamination for the compounds. Follow-up analyses by NWQL confirmed the presence of these compounds in the buffer added to samples
(Mark Sandstrom, U.S. Geological Survey, oral commun., 2005).

For 9 of the 14 compounds detected in more than 5 percent of field blanks (table 5), the occurrence of these compounds in field blanks was evaluated to determine if detections were associated with specific sites. If a compound was detected in 50 percent or more of field blanks from a site, all of the data for that constituent at that site were removed from the data set. If a compound was detected in 5 percent or more of field blanks collected at the remaining sites, the environmental data for that compound were censored at the highest field blank concentration to account for the potential bias indicated by field blanks. If a compound was detected in less than 5 percent of remaining field blanks after removal of field blanks from sites with greater than 50 percent occurrence in field blanks, no additional censoring was done.

Twenty other compounds were detected infrequently (less than 5 percent) at low concentrations in field blanks (Appendix 1). Most of these compounds were detected at concentrations less than the LRL, and 18 of these compounds were detected only once in a field blank. Detection frequencies for many of these compounds were higher in environmental samples than in field blanks, and the field blank concentrations were less than many of the environmental concentrations. Data

Table 5. Summary of compounds detected in 5 percent or more of field blanks collected for Source Water-Quality Assessment studies, 2002-05.

[N, number of field blanks; USGS, U.S. Geological Survey; $\mu \mathrm{g} / \mathrm{L}$, micrograms per liter; DEET, N,N-diethyl-meta-toluamide]

\begin{tabular}{|c|c|c|c|c|}
\hline Compound (N) & $\begin{array}{l}\text { USGS } \\
\text { parameter } \\
\text { code }\end{array}$ & $\begin{array}{l}\text { Number of stream sites } \\
\text { for which compound was } \\
\text { removed from all samples } \\
\text { in data set }\end{array}$ & $\begin{array}{l}\text { Number of detections } \\
\text { censored at the } \\
\text { maximum field blank } \\
\text { concentration }\end{array}$ & $\begin{array}{c}\text { Maximum field } \\
\text { blank } \\
\text { concentration, } \\
(\mu \mathrm{g} / \mathrm{L})\end{array}$ \\
\hline \multicolumn{5}{|c|}{ Compounds removed from data set } \\
\hline Benzophenone (45) & 62067 & 9 & All data removed & 0.09 \\
\hline DEET (45) & 62082 & 9 & All data removed & .66 \\
\hline Isophorone (45) & 34409 & 9 & All data removed & .09 \\
\hline para-Nonylphenol (total) (45) & 62085 & 9 & All data removed & 2.3 \\
\hline Phenol (45) & 34466 & 9 & All data removed & 2.0 \\
\hline \multicolumn{5}{|c|}{ Compounds removed from stream site or censored at highest field blank concentration } \\
\hline Benzene (46) & 34030 & 1 & 0 & 0.04 \\
\hline Caffeine (25) & 50305 & 1 & 28 & .01 \\
\hline Toluene (46) & 34010 & 1 & 148 & .05 \\
\hline Tributyl phosphate (45) & 62089 & 2 & 0 & .17 \\
\hline \multicolumn{5}{|c|}{ Compounds censored at highest field blank concentration } \\
\hline Acetophenone (45) & 62064 & 0 & 7 & 0.49 \\
\hline Acetone (46) & 81552 & 0 & 39 & 3.67 \\
\hline Bisphenol A (38) & 62069 & 0 & 46 & 1.60 \\
\hline Methyl salicylate (45) & 62081 & 0 & 34 & .07 \\
\hline Phenanthrene (45) & 34462 & 0 & 26 & .04 \\
\hline
\end{tabular}


for these compounds are included in summary tables because the potential for contamination in the environmental samples was considered to be low and did not affect the overall interpretation of the study results.

Prior to implementation of the addition of ascorbic acid (quenching agent) to finished-water samples during the second phase of sampling, NWQL evaluated the effect of this quenching agent and buffer on compound recoveries. Results indicated that recoveries were not affected by the addition of these reagents (Mark Sandstrom, U.S. Geological Survey, written commun., 2006). Additionally, during the second sampling phase, matrix spikes were collected to further characterize analytical method performance with the addition of ascorbic acid to finished-water samples. Results to date (2008) indicate that median spike recoveries generally were within acceptable limits for most compounds that are not always reported as estimated concentrations (Valder and others, 2008). Results of paired spiked finished-water samples, one with quenching reagents added and the other without, indicate that several compounds degrade in the presence of free chlorine (Valder and others, 2008). These results highlight the fact that additional contact time of finished water in the distribution system would affect the concentrations of several compounds analyzed in this study. Environmental and selected qualityassurance data for this study are available in Carter and others (2007).

\section{Human-Health Benchmarks used in a Screening-Level Assessment}

Annual mean concentrations for regulated compoundsthose with USEPA MCLs - were compared to MCLs, and annual mean concentrations of unregulated compounds - those without USEPA MCLs - were compared to Health-Based Screening Levels (HBSLs), when available (Toccalino and others, 2003; Toccalino, Norman, and others, 2006). Comparisons to human-health benchmarks are used in this report to identify concentrations of potential human-health concern and to provide an initial perspective on the potential importance of the anthropogenic organic compounds detected.

Thirty-eight of the compounds monitored in this study have an established USEPA MCL (U.S. Environmental Protection Agency, 2006c) and 110 have an HBSL (Toccalino, 2007). HBSLs have not been developed for the remaining 129 unregulated compounds because of a lack of toxicity information. Therefore, the potential human-health significance of these compounds cannot be evaluated at this time (Toccalino, Rowe, and Norman, 2006).

MCLs are legally enforceable USEPA drinking-water standards that set the maximum permissible level of a contaminant in water that is delivered by public water systems (U.S. Environmental Protection Agency, 2008a). The permissible level, depending on the contaminant, may be defined in terms of a single sample concentration or in terms of an annual mean concentration or other longer-term concentration statistic; HBSLs are benchmark concentrations of compounds in water that, if exceeded, may be of potential concern for human health. HBSLs are not regulatory standards, are not enforceable, and water systems are not required to monitor for any compounds for which HBSLs have been developed. HBSLs were developed collaboratively by the USGS, USEPA, New Jersey Department of Environmental Protection, and Oregon Health \& Science University (Toccalino and others, 2003). The values were developed using USEPA Office of Water methodologies and USEPA toxicity values, so they generally are comparable to USEPA drinking-water guideline values such as Lifetime Health Advisory levels and Risk-Specific Dose Values (Toccalino and others, 2003).

HBSLs, as well as most MCLs, are maximum mean contaminant concentrations that are not expected to cause adverse health effects over a lifetime (70 years) of exposure to finished drinking water (Toccalino, 2007; U.S. Environmental Protection Agency, 2008a). MCLs are applicable only to finished-water samples in the regulatory framework; however, an assessment of source-water concentrations in relation to human-health benchmarks provides an indication to water-resource managers and CWSs of potential concerns in the absence of the effects of factors such as water treatment and distribution. In surface water, contaminant concentrations can change substantially over time and have strong seasonal patterns. Annual or long-term mean concentrations (determined from multiple samples over a period of time and timeweighted) generally are most appropriate for comparison to MCLs or HBSLs because mean concentrations provide a more reliable indication of long-term exposure than concentrations in individual samples (Toccalino, 2007). In this study, annual mean concentrations were compared to human-health benchmarks to assess potential concerns. For these comparisons, annual mean benchmark quotient (BQ) values, the ratio of an annual mean concentration of a compound to its benchmark, were calculated.

Concentrations of compounds in single samples of both source water and finished water also were compared to these human-health benchmarks as an additional screening-level assessment. This comparison identifies compounds with concentrations that approached or were greater than benchmarks to aid in assessing their potential significance. A BQ value greater than 1.0 represents a concentration greater than or equal to a benchmark. A BQ value greater than or equal to 0.1 can be used to identify compounds that may warrant additional monitoring (Toccalino, Rowe, and Norman, 2006). A threshold BQ of 0.1 is consistent with various State and Federal practices (for example, see U.S. Environmental Protection Agency, 1998a). Monitoring for these contaminants would enable analysis of trends in their occurrence and may provide an early indication if concentrations approach human-health benchmarks. Also in this report, BQmax is used to represent the ratio of the maximum measured concentration for a compound compared to its human-health benchmark. All $B Q$ values are rounded to two significant figures. 


\section{Annual Mean Concentration Calculations}

CWSs where surface water is the source of drinking water are required to collect quarterly samples during compliance monitoring under the Safe Drinking Water Act of 1996. Results of a sample are averaged with the previous three quarterly samples to determine whether running average concentrations in finished water are less than MCLs (U.S. Environmental Protection Agency, 1998b). In this study, annul mean concentrations were calculated for both phases of sampling at each site. At most sites, samples were collected over about a 12-month period in each phase, but in some cases the sampling period was somewhat longer or shorter than 12 months (table 4). The minimum number of samples collected for calculation of an annual mean concentration was eight samples from the CWS on the Truckee River during the second sampling phase. Results for all samples were used for calculating the annual mean concentration at each site, and a value of one-half of the LRL was used for samples in which a compound was not detected. This approach represents a conservative estimate of the annual mean concentration.

\section{Anthropogenic Organic Compounds in Source Water Sampled During 2002-04}

A total of 134 of the 258 anthropogenic organic compounds analyzed at all sites were detected in at least one source-water sample collected at nine CWSs during the first phase of sampling, October 2002 through March 2004. A total of 119 compounds were not detected in any sample ( 5 compounds were removed from the data set because of data-quality concerns). At least one compound was detected from each of the 13 use groups in which the compounds were categorized, with the exception of refrigerants and propellants (Appendix 1). Results were evaluated with no assessment level (all detections) and with an assessment level of $0.1 \mu \mathrm{g} / \mathrm{L}$ (fig. 2). Compounds are characterized as commonly occurring in this report when they were detected in 10 percent or more of samples among all sites combined or in more than 75 percent of samples from at least one site using no assessment level. By this definition, 47 compounds were detected commonly. Of these compounds, chloroform, simazine, atrazine, deethylatrazine, metolachlor, and hexahydrohexamethylcyclopentabenzopyran (HHCB) were detected in more than one-half of the source-water samples. The commonly detected compounds represented nine of the use groups and did not include the fumigant-related, pavement- and combustion-derived, organic synthesis, or refrigerants and propellants use groups.

Detection frequencies of most compounds were less than 10 percent on the basis of the common assessment level of $0.1 \mu \mathrm{g} / \mathrm{L}$, and only 15 compounds in six of the primary use groups had detection frequencies greater than 10 percent (fig. 2 and Appendix 1). A few compounds, such as cholesterol, had the same detection frequency with and without the application of a common assessment level. These compounds have an LRL that is greater than $0.1 \mu \mathrm{g} / \mathrm{L}$, and all detected concentrations were greater than that concentration. At the common assessment level, compounds from six of the use groups were detected, with herbicides and herbicide degradates being detected most commonly. The smaller detection frequencies that were based on a common assessment level compared to using no assessment level illustrate the low concentrations at which many of these compounds were detected.

\section{Commonly Detected Compounds}

Most of the commonly detected compounds were present in samples from several sites, and only three compounds - alachlor, acetochlor, and cis-1,2-dichlorothene (cis-1,2-DCE) - were not detected at more than two sites (table 6). Localized occurrence of these compounds likely represents the presence of either a nearby point source, use of a compound for a specific purpose (for example, an herbicide that is applied to a specific crop that is grown only in one of the watersheds), or ground-water discharge that is contaminated from an industrial site or landfill. The fact that acetochlor was detected predominantly at one site is related to its use as an herbicide for corn cultivation. The occurrence of acetochlor was largely limited to samples collected from the White River in Indiana, which drains a large amount of cultivated land (table 1).

Herbicides and herbicide degradates were among the most commonly detected compounds in source-water samples collected during the first phase of sampling. Their frequent detection is due, in large part, to their widespread use and lower reporting levels compared to other compounds (fig. 2 and Appendix 1). The most commonly detected herbicidessimazine, atrazine and its degradates (deethylatrazine and deisopropylatrazine), metolachlor, prometon, and 2,4-Dwere detected in about 50 percent or more of samples at six of the nine sites. Sima-zine, atrazine, deethylatrazine, and metolachlor were detected year round in samples from the Elm Fork Trinity, Potomac, and White Rivers. The most commonly detected herbicides have both agricultural and non-agricultural uses. Atrazine and metolachlor are two of the most heavily used agricultural herbicides in the country with much of the use for corn production; however, both herbicides also are used in urban areas (Gilliom and others, 2006). Simazine, prometon, and 2,4-D have considerable use for weed control in areas not associated with agriculture, such as use on turfgrass, lawns, roadsides, and railroads, and simazine and 2,4-D also are used for agriculture (Gilliom and others, 2006). The common occurrence of these herbicides in both agricultural and non-agricultural settings is, in part, a result of the large amounts of agricultural or mixed land use (including some urban) that characterizes the contributing watersheds, and the relatively large amounts of these herbicides that are used (Gilliom and others, 2006). 


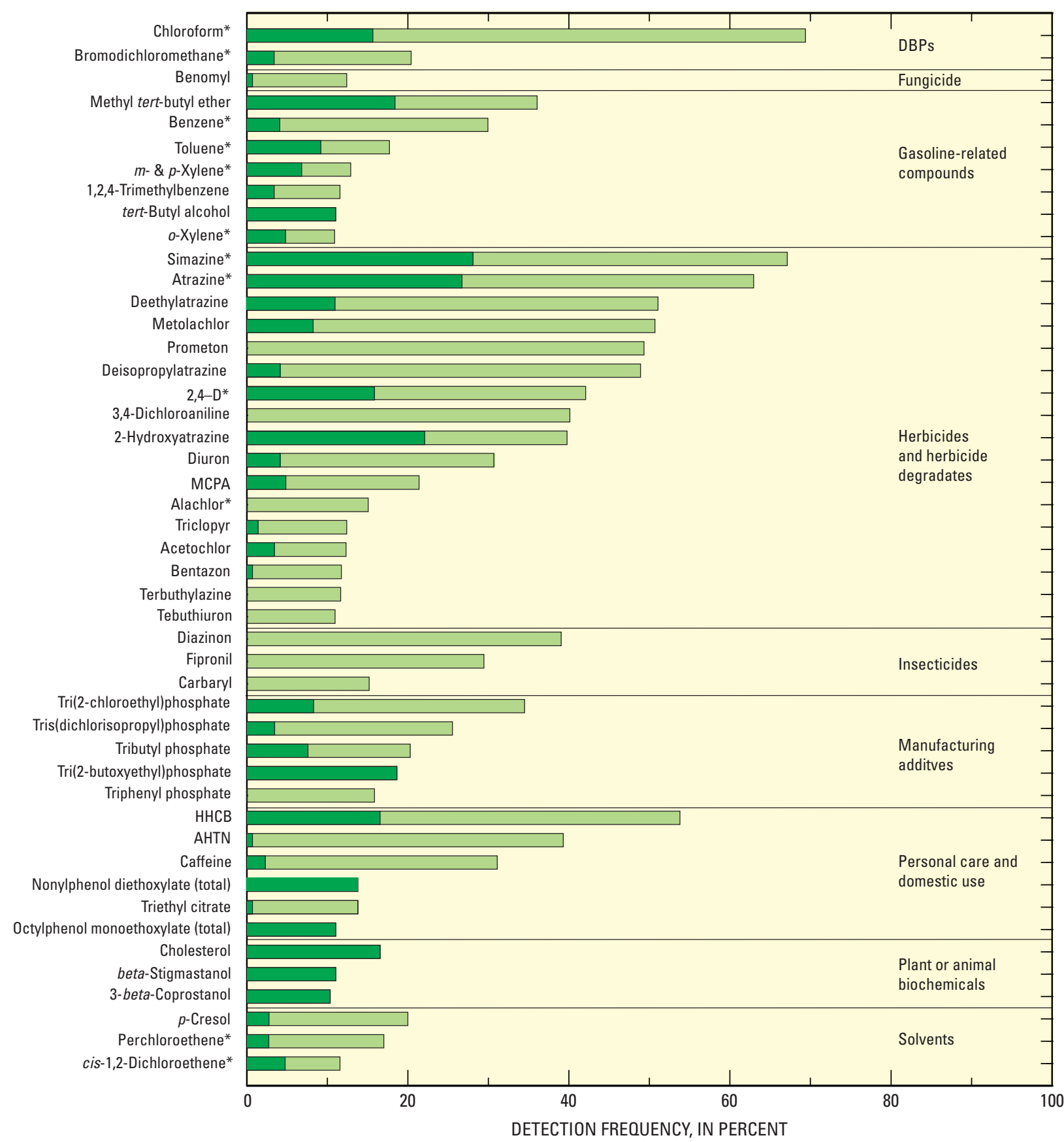

EXPLANATION

\begin{abstract}
All detections
Detections at concentrations greater than or equal to an assessment level of 0.1 microgram per liter

Note: If bar is all light green, the compound was not detected at a concentration equal to or greater than 0.1 microgram per liter. Conversely, if bar is all dark green, the compound was not detected at a concentration less than 0.1 microgram per liter.
\end{abstract}

\author{
* Regulated compound \\ DBP Disinfection by-product \\ MCPA 2-methyl-4-chlorophenoxyacetic acid \\ HHCB Hexahydrohexamethylcyclopentabenzopyran \\ AHTN Acetyl hexamethyl tetrahydronaphthalene
}

Figure 2. Forty-seven of 258 anthropogenic organic compounds were detected using no common assessment level in 10 percent or more of source-water samples collected at nine community water systems (CWSs) during the first phase of sampling, October 2002 through March 2004. 
Table 6. Detection frequency by site for commonly detected compounds in source-water samples collected during the first phase of sampling, 0ctober 2002-March 2004.

[Commonly detected compounds were in 10 percent or more of samples. Stream sites are arranged from left to right by increasing agricultural land use. Compounds in each primary-use group are arranged in descending detection frequency. No assessment level was used to determine detection frequency. N, typical number of samples-the number of analyses may vary for some compounds; AHTN, acetyl hexamethyl tetrahydronaphthalene; HHCB, hexahydrohexamethylcyclopentabenzopyran; MCPA, 2-methyl-4-chlorophenoxyacetic acid; ND, not detected; --, no data, data removed]

\begin{tabular}{|c|c|c|c|c|c|c|c|c|c|c|}
\hline $\begin{array}{c}\text { Anthropogenic } \\
\text { organic } \\
\text { compound }\end{array}$ & $\begin{array}{c}\text { Overall } \\
\text { detection } \\
\text { frequency, } \\
\text { in percent }\end{array}$ & $\begin{array}{c}\text { Cache la } \\
\text { Poudre River, } \\
\text { Colorado } \\
\text { (N=17) }\end{array}$ & $\begin{array}{c}\text { Truckee } \\
\text { River, } \\
\text { Nevada } \\
\text { (N=17) }\end{array}$ & $\begin{array}{l}\text { Clackamas } \\
\text { River, } \\
\text { Oregon } \\
\text { (N=17) }\end{array}$ & $\begin{array}{l}\text { Running Gutter } \\
\text { Brook, Massa- } \\
\text { chusetts } \\
(\mathrm{N}=16)\end{array}$ & $\begin{array}{c}\text { Chatta- } \\
\text { hoochee } \\
\text { River, } \\
\text { Georgia } \\
\text { (N=17) }\end{array}$ & $\begin{array}{c}\text { Neuse River, } \\
\text { North } \\
\text { Carolina } \\
\text { (N=17) }\end{array}$ & $\begin{array}{l}\text { Potomac River, } \\
\text { Maryland } \\
\text { (N=12) }\end{array}$ & $\begin{array}{c}\text { Elm Fork } \\
\text { Trinity River, } \\
\text { Texas } \\
(\mathrm{N}=17)\end{array}$ & $\begin{array}{c}\text { White River, } \\
\text { Indiana } \\
\text { ( } N=17)\end{array}$ \\
\hline \multicolumn{11}{|c|}{ Disinfection by-products } \\
\hline Chloroform & 69 & ND & 6 & 39 & 100 & 94 & 100 & 100 & 100 & 100 \\
\hline Bromodichloromethane & 20 & ND & ND & 6 & 27 & 18 & 6 & 17 & 71 & 41 \\
\hline \multicolumn{11}{|c|}{ Fungicides } \\
\hline Benomyl & 12 & ND & ND & ND & ND & 53 & 25 & 8 & 12 & 18 \\
\hline \multicolumn{11}{|c|}{ Gasoline hydrocarbons, oxygenates, and oxygenate degradates } \\
\hline $\begin{array}{l}\text { Methyl tert-butyl ether } \\
\text { (MTBE) }\end{array}$ & 36 & ND & ND & ND & 47 & 41 & 76 & 67 & 100 & 6 \\
\hline Benzene & 31 & 24 & 12 & 67 & 27 & -- & 47 & 17 & 24 & 24 \\
\hline Toluene & 18 & ND & 12 & 56 & ND & 29 & 18 & 17 & -- & 6 \\
\hline$m$ - and $p$-Xylene & 13 & ND & 6 & 56 & ND & 12 & 6 & 17 & 6 & 12 \\
\hline 1,2,4-Trimethylbenzene & 12 & ND & 6 & 56 & ND & 12 & 6 & 8 & 6 & 6 \\
\hline tert-Butyl alcohol & 11 & ND & ND & ND & ND & 13 & 35 & ND & 47 & ND \\
\hline$o$-Xylene & 11 & ND & 6 & 56 & ND & 6 & 6 & 8 & 6 & 6 \\
\hline \multicolumn{11}{|c|}{ Herbicides and herbicide degradates } \\
\hline Simazine & 67 & ND & ND & 53 & 63 & 100 & 100 & 100 & 100 & 100 \\
\hline Atrazine & 64 & ND & 6 & 29 & 75 & 100 & 76 & 100 & 100 & 100 \\
\hline Deethylatrazine & 52 & ND & 18 & 18 & 31 & 47 & 71 & 100 & 100 & 100 \\
\hline Metolachlor & 51 & ND & ND & 18 & 13 & 41 & 100 & 100 & 100 & 100 \\
\hline Deisopropylatrazine & 49 & ND & ND & ND & 82 & 53 & 38 & 8 & 100 & 88 \\
\hline Prometon & 49 & ND & ND & 6 & ND & 94 & 100 & 92 & 65 & 100 \\
\hline $2,4-\mathrm{D}$ & 43 & ND & ND & 6 & ND & 87 & 69 & 58 & 82 & 94 \\
\hline 2-Hydroxyatrazine & 40 & ND & ND & ND & ND & 47 & 50 & 92 & 100 & 100 \\
\hline 3,4-Dichloroaniline & 40 & ND & ND & ND & ND & 94 & 88 & 17 & 94 & 63 \\
\hline Diuron & 30 & ND & 6 & 47 & ND & 40 & 38 & 25 & 100 & 18 \\
\hline MCPA & 21 & ND & ND & ND & ND & 67 & 25 & 33 & 53 & 24 \\
\hline Alachlor & 15 & ND & ND & ND & ND & ND & ND & ND & 65 & 69 \\
\hline
\end{tabular}


Table 6. Detection frequency by site for commonly detected compounds in source-water samples collected during the first phase of sampling, 0 ctober 2002-March 2004. - Continued

[Commonly detected compounds were in 10 percent or more of samples. Stream sites are arranged from left to right by increasing agricultural land use. Compounds in each primary-use group are arranged in descending detection frequency. No assessment level was used to determine detection frequency. N, typical number of samples-the number of analyses may vary for some compounds; AHTN, acetyl hexamethyl tetrahydronaphthalene; HHCB, hexahydrohexamethylcyclopentabenzopyran; MCPA, 2-methyl-4-chlorophenoxyacetic acid; ND, not detected; --, no data, data removed]

\begin{tabular}{|c|c|c|c|c|c|c|c|c|c|c|}
\hline $\begin{array}{c}\text { Anthropogenic } \\
\text { organic } \\
\text { compound }\end{array}$ & $\begin{array}{c}\text { Overall } \\
\text { detection } \\
\text { frequency, } \\
\text { in percent }\end{array}$ & $\begin{array}{c}\text { Cache la } \\
\text { Poudre River, } \\
\text { Colorado } \\
\text { (N=17) }\end{array}$ & $\begin{array}{c}\text { Truckee } \\
\text { River, } \\
\text { Nevada } \\
\text { (N=17) }\end{array}$ & $\begin{array}{l}\text { Clackamas } \\
\text { River, } \\
\text { Oregon } \\
\text { (N=17) }\end{array}$ & $\begin{array}{c}\text { Running Gutter } \\
\text { Brook, Massa- } \\
\text { chusetts } \\
(\mathrm{N}=16)\end{array}$ & $\begin{array}{c}\text { Chatta- } \\
\text { hoochee } \\
\text { River, } \\
\text { Georgia } \\
\text { (N=17) }\end{array}$ & $\begin{array}{c}\text { Neuse River, } \\
\text { North } \\
\text { Carolina } \\
\text { (N=17) }\end{array}$ & $\begin{array}{l}\text { Potomac River, } \\
\text { Maryland } \\
\text { (N=12) }\end{array}$ & $\begin{array}{c}\text { Elm Fork } \\
\text { Trinity River, } \\
\text { Texas } \\
(\mathrm{N}=17)\end{array}$ & $\begin{array}{c}\text { White River, } \\
\text { Indiana } \\
(\mathrm{N}=17)\end{array}$ \\
\hline \multicolumn{11}{|c|}{ Herbicides and herbicide degradates - Continued } \\
\hline Acetochlor & 12 & ND & ND & ND & ND & ND & ND & 17 & ND & 100 \\
\hline Bentazon & 12 & ND & ND & ND & ND & ND & 6 & ND & 6 & 88 \\
\hline Terbuthylazine & 12 & ND & ND & ND & ND & 6 & 47 & ND & ND & 50 \\
\hline Triclopyr & 12 & ND & ND & ND & ND & 40 & 6 & 17 & 12 & 41 \\
\hline Tebuthiuron & 11 & ND & ND & ND & ND & 18 & 12 & ND & 47 & 18 \\
\hline \multicolumn{11}{|c|}{ Insecticides and insecticide degradates } \\
\hline Diazinon & 39 & ND & ND & 12 & ND & 59 & 82 & 33 & 94 & 65 \\
\hline Fipronil & 29 & ND & ND & ND & ND & 59 & 88 & 17 & 41 & 56 \\
\hline Carbaryl & 15 & ND & ND & 18 & ND & 47 & 31 & 33 & 29 & 6 \\
\hline \multicolumn{11}{|c|}{ Manufacturing additives } \\
\hline $\begin{array}{l}\text { Tri(2-chloroethyl)phos- } \\
\text { phate }\end{array}$ & 34 & ND & 6 & ND & 7 & 56 & 71 & 33 & 88 & 47 \\
\hline $\begin{array}{l}\text { Tris(dichlorisopropyl)- } \\
\text { phosphate }\end{array}$ & 26 & ND & ND & ND & ND & 44 & 53 & 25 & 71 & 35 \\
\hline Tributyl phosphate & 20 & ND & ND & 6 & -- & 31 & 35 & -- & 53 & 18 \\
\hline $\begin{array}{l}\text { Tri(2-butoxyethyl)phos- } \\
\text { phate }\end{array}$ & 19 & ND & ND & ND & ND & 38 & 29 & 17 & 53 & 29 \\
\hline Triphenyl phosphate & 16 & 6 & ND & 6 & ND & 38 & 24 & 17 & 35 & 18 \\
\hline \multicolumn{11}{|c|}{ Personal-care and domestic-use products } \\
\hline HHCB & 53 & 6 & 24 & ND & 27 & 81 & 88 & 67 & 100 & 94 \\
\hline AHTN & 39 & ND & ND & ND & 20 & 75 & 82 & 25 & 71 & 76 \\
\hline Caffeine & 31 & 6 & 18 & 6 & 12 & 50 & 41 & -- & 29 & 65 \\
\hline $\begin{array}{l}\text { 4-Nonylphenol di- } \\
\text { ethoxylate (total) }\end{array}$ & 14 & 6 & ND & ND & 13 & 25 & 29 & 8 & 18 & 24 \\
\hline $\begin{array}{l}\text { Triethyl citrate (ethyl } \\
\text { citrate) }\end{array}$ & 14 & ND & ND & ND & ND & 19 & 24 & 8 & 29 & 41 \\
\hline $\begin{array}{l}\text { 4-Octylphenol mono- } \\
\text { ethoxylate (total) }\end{array}$ & 11 & 6 & ND & ND & 13 & 25 & 18 & 17 & 12 & 12 \\
\hline
\end{tabular}


Table 6. Detection frequency by site for commonly detected compounds in source-water samples collected during the first phase of sampling, 0ctober 2002-March 2004. - Continued

[Commonly detected compounds were in 10 percent or more of samples. Stream sites are arranged from left to right by increasing agricultural land use. Compounds in each primary-use group are arranged in descending detection frequency. No assessment level was used to determine detection frequency. N, typical number of samples-the number of analyses may vary for some compounds; AHTN, acetyl hexamethyl tetrahydronaphthalene; HHCB, hexahydrohexamethylcyclopentabenzopyran; MCPA, 2-methyl-4-chlorophenoxyacetic acid; ND, not detected; --, no data, data removed]

\begin{tabular}{|c|c|c|c|c|c|c|c|c|c|c|}
\hline $\begin{array}{l}\text { Anthropogenic } \\
\text { organic } \\
\text { compound }\end{array}$ & $\begin{array}{c}\text { Overall } \\
\text { detection } \\
\text { frequency, } \\
\text { in percent }\end{array}$ & $\begin{array}{c}\text { Cache la } \\
\text { Poudre River, } \\
\text { Colorado } \\
\text { (N=17) }\end{array}$ & $\begin{array}{c}\text { Truckee } \\
\text { River, } \\
\text { Nevada } \\
\text { (N=17) }\end{array}$ & $\begin{array}{l}\text { Clackamas } \\
\text { River, } \\
\text { Oregon } \\
\text { (N=17) }\end{array}$ & $\begin{array}{l}\text { Running Gutter } \\
\text { Brook, Massa- } \\
\text { chusetts } \\
(N=16)\end{array}$ & $\begin{array}{c}\text { Chatta- } \\
\text { hoochee } \\
\text { River, } \\
\text { Georgia } \\
\text { (N=17) }\end{array}$ & $\begin{array}{c}\text { Neuse River, } \\
\text { North } \\
\text { Carolina } \\
\text { (N=17) }\end{array}$ & $\begin{array}{l}\text { Potomac River, } \\
\text { Maryland } \\
\text { (N=12) }\end{array}$ & $\begin{array}{c}\text { Elm Fork } \\
\text { Trinity River, } \\
\text { Texas } \\
(\mathbf{N}=17)\end{array}$ & $\begin{array}{c}\text { White River, } \\
\text { Indiana } \\
\text { (N=17) }\end{array}$ \\
\hline \multicolumn{11}{|c|}{ Plant- or animal-derived biochemicals } \\
\hline Cholesterol & 17 & ND & ND & 6 & ND & 31 & 47 & 25 & 18 & 24 \\
\hline beta-Stigmastanol & 11 & ND & ND & ND & ND & 25 & 35 & 8 & 12 & 18 \\
\hline 3-beta-Coprostanol & 10 & ND & ND & ND & ND & 13 & 29 & 25 & 12 & 18 \\
\hline \multicolumn{11}{|c|}{ Solvents } \\
\hline$p$-Cresol & 20 & 12 & 41 & 18 & 13 & 31 & 24 & 8 & 18 & 12 \\
\hline Perchloroethene (PCE) & 17 & ND & ND & ND & ND & ND & 41 & ND & 18 & 88 \\
\hline cis-1,2-Dichloroethene & 12 & ND & ND & ND & ND & ND & ND & ND & ND & 100 \\
\hline
\end{tabular}


The five herbicides detected most commonly in sourcewater samples also were among those detected most frequently in ambient water collected as part of NAWQA studies from 156 streams across the Nation during 1992-2001, including 83 agricultural, 8 undeveloped, and 65 mixed-land use watersheds (fig. 3) (Gilliom and others, 2006). Detection frequencies by land use generally are comparable for sourcewater sites sampled in this study on the basis of all detections, except in undeveloped streams (fig. 3). These herbicides, with the exception of simazine, were detected less commonly in source-water samples than in ambient stream samples collected in the relatively undeveloped streams (fig. $3 A$ ). This difference may be because three of the four sourcewater sites are in the western part of the United States, where simazine, atrazine, and metolachlor are used less than in the Midwest and eastern United States (Gilliom and others, 2006). Conversely, most herbicides (with the exception of deethylatrazine) were detected more commonly in sourcewater samples collected in the mixed and agricultural landuse watersheds in this study than in ambient stream samples (figs. $3 B$ and $3 C$ ), which may be because the source-water samples were from streams in the Midwest and East where these herbicides have much greater use than in other parts of the United States (Gilliom and others, 2006). Differences in occurrence in mixed and agricultural land-use settings were somewhat larger using a common assessment level of $0.1 \mu \mathrm{g} / \mathrm{L}$ (figs. $3 B$ and $3 C$ ). Most notably, simazine was detected more frequently in this study in both of these settings, perhaps because most of these sites are located in urban or suburban areas of the watershed.

Previous studies indicate that herbicide degradates typically occur with their parent compounds at concentrations similar to or greater than concentrations of their parent compounds (Thurman and others, 1992; Kalkhoff and others, 1998; Gilliom and others, 2006). For many degradates, little is known about their occurrence or their effects on human health. With a few exceptions for pesticides and degradates with known common modes of action, drinking-water standards or human-health benchmarks are not available for most pesticide degradates.

Several degradates, principally those of atrazine and other triazine herbicides, as well as 3,4-dichloroaniline (a degradate of diuron), were analyzed in samples collected at all source-water sites and were detected commonly during this study (fig. 2). These degradates usually were present when the parent herbicide was detected in source-water samples, and concentrations typically were less than those of the parent herbicide. Degradates generally were as common in source water as the parent pesticide. For example, at the Potomac, Elm Fork Trinity, and White Rivers, both atrazine and its degradate deethylatrazine were detected in all samples (table 6).

Degradates of the chloroacetanilide herbicides metolachlor, alachlor, and acetochlor were analyzed in samples collected from the Neuse, Potomac, and White Rivers. These sites included areas where these herbicides had potential use for agriculture. Similar to results for degradates of atrazine, these degradates usually were detected with the parent compounds; however, the summed concentrations of degradates of metolachlor and alachlor typically were similar to or greater than the parent herbicide concentration (fig. 4). Results for degradates of acetochlor were similar to those of metolachlor, but acetochlor was detected only at the White River site. In samples from the Potomac River, however, alachlor was not detected even though its degradate alachlor ethane sulfonic acid was detected in about 75 percent of samples. This pattern was observed despite the fact that the LRL for alachlor is about an order of magnitude lower than the LRL for its degradates. This difference in occurrence between atrazine and chloroacetanilide degradates is most likely due to differences in the chemical properties of the parent herbicides. Specifically, atrazine is more mobile and chemically stable than metolachlor and alachlor, allowing atrazine to persist in the hydrologic system longer. These results highlight the fact that for some pesticides information on the occurrence of degradates may be as important as information for the parent compound particularly if the degradate toxicity or mode of action is similar to that of the parent compound.

The insecticides diazinon, fipronil, and carbaryl were detected in samples from as many as six of the nine sites (table 6). Fipronil and carbaryl were detected in 29 and 15 percent of samples, respectively. Diazinon had the largest detection frequency of the three insecticides and was present in 39 percent of samples. It was detected in almost all of the samples from the Elm Fork Trinity River and in samples from five other sites. Both diazinon and carbaryl were among the most commonly detected insecticides in streams sampled by the NAWQA Program, and detection frequencies were highest in watersheds characterized as urban (Gilliom and others, 2006). Insecticides were not detected in samples from three sites (table 6); the watersheds for two of these sites included less than 1 percent urban land use.

Several of the most commonly detected compounds may be contributed to surface waters from municipal or industrial wastewater discharge. For example, chloroform may be present in treated wastewater because of the household use of bleach as well as the disinfection of wastewater during the treatment process (Ivahnenko and Barbash, 2004). Chloroform was the most commonly detected compound in source water (69 percent of samples), and was present in samples from eight of the nine sites (table 6). It also was detected year-round (in all samples) at five of the nine sites. Other possible sources of chloroform include its use as a refrigerant for home air conditioners and large commercial freezers, and it also has been used in reagents, extraction solvents, fumigants, insecticides, and as a precursor for dyes and pesticides. Caffeine, HHCB, and acetyl hexamethyl tetrahydronaphthalene (AHTN) may be introduced to surface waters in wastewater discharge. The fragrance compounds HHCB and AHTN commonly are used in detergents and other personal-care products and have been found in both influent and effluent of wastewater-treatment plants in the United States and Europe (Bester, 2004; Phillips 


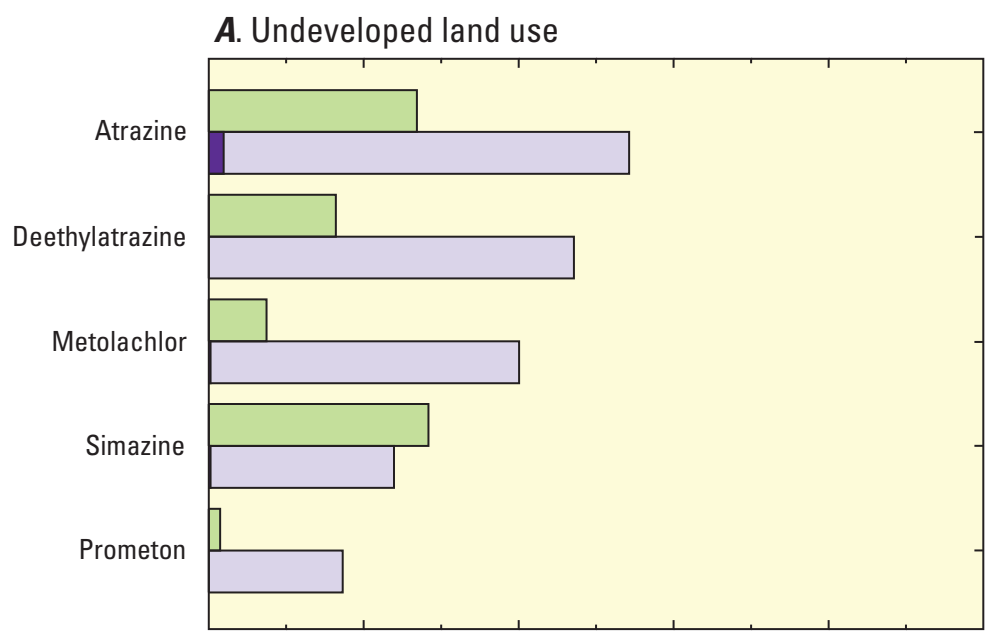

\section{EXPLANATION}

Source Water-Quality Assessment sites

$\square$ Detection frequency based on all detections

Detection frequency based on an assessment level of 0.1 microgram per liter

\section{National stream data}

Detection frequency based on all detections

Detection frequency based on an assessment level of 0.1 microgram per liter
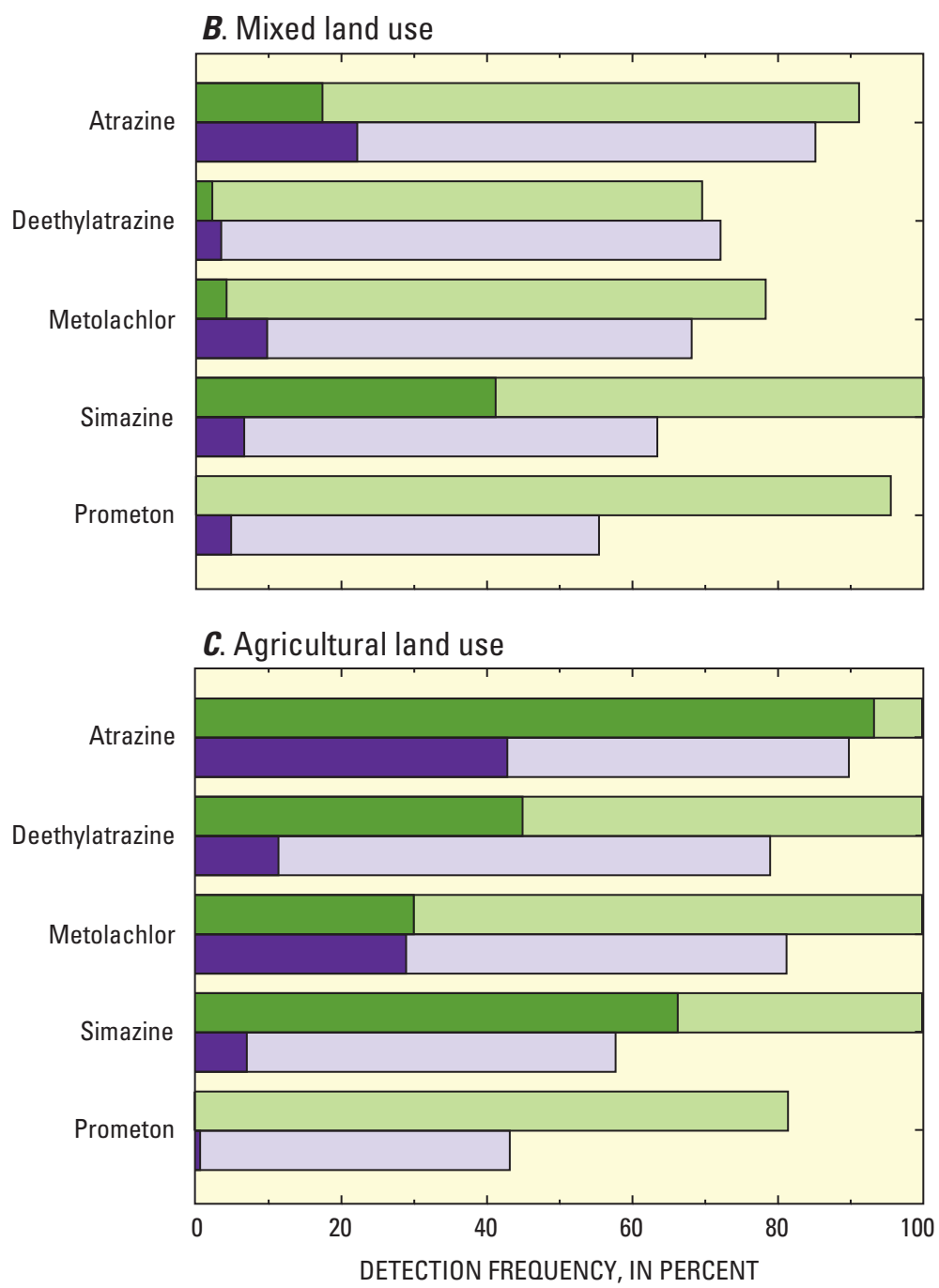

Figure 3. The herbicides most commonly detected in source-water samples from Source Water-Quality Assessment (SWQA) sites collected during the first phase of sampling, October 2002-March 2004, correspond to those detected most frequently in 156 streams across the Nation sampled by the National Water-Quality Assessment (NAWQA) Program (1992-2001) (Gilliom and others, 2006) in $A$, undeveloped; $B$, mixed; and $C$, agricultural land-use areas. 

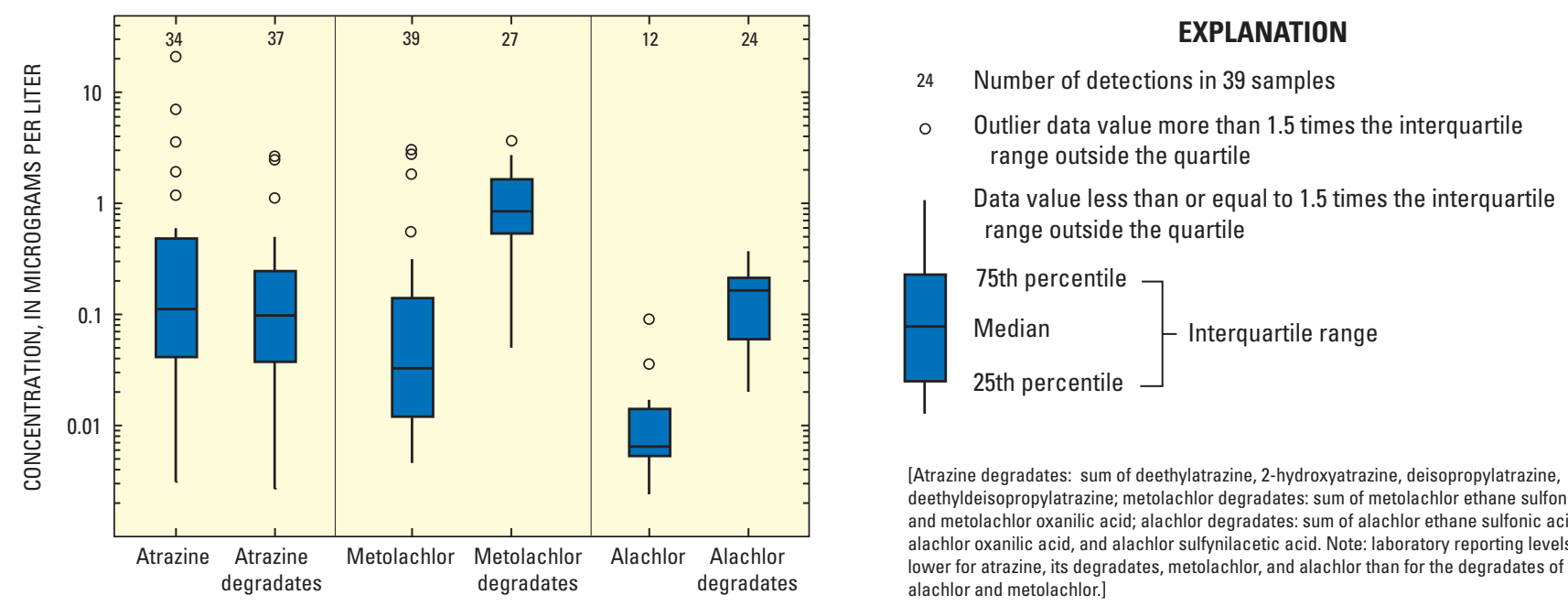

[Atrazine degradates: sum of deethylatrazine, 2-hydroxyatrazine, deisopropylatrazine, and deethyldeisopropylatrazine; metolachlor degradates: sum of metolachlor ethane sulfonic acid and metolachlor oxanilic acid; alachlor degradates: sum of alachlor ethane sulfonic acid, alachlor oxanilic acid, and alachlor sulfynilacetic acid. Note: laboratory reporting levels are lower for atrazine, its degradates, metolachlor, and alachlor than for the degradates of alachlor and metolachlor.]

Figure 4. The distributions of concentrations of herbicide degradates were similar to or greater than concentrations of parent compounds in source-water samples collected from the Neuse, Potomac, and White Rivers during the first phase of sampling, October 2002-March 2004.

and others, 2005). Manufacturing additives, such as tri(2-chloroethyl)phosphate and tris(dichlorisopropyl)phosphate, and the biochemicals cholesterol and 3-beta-coprostanol were detected in a national reconnaissance of emerging contaminants in surface waters that receive a substantial amount of municipal, industrial, or agricultural wastewater discharge (Kolpin and others, 2002). These biochemicals may be contributed to streams with wastewater discharge, but they also occur naturally in the environment.

Seven gasoline hydrocarbons and oxygenates were commonly detected (fig. 2 and Appendix 1). Methyl tert-butyl ether (MTBE), an oxygenate, was detected in 36 percent of the samples, representing six of the nine sites and was in all of the samples collected from the Elm Fork Trinity River (table 6). The other gasoline hydrocarbons were detected periodically at several of the sites, but more than one-half of the samples from the Clackamas River had detections of several gasoline hydrocarbons (table 6). These compounds may be contributed to surface waters from ground-water discharge that is contaminated, runoff from roads and parking lots, and watercraft that are used on these streams or upstream reservoirs. The results in this study are similar to results from a study of the occurrence of VOCs in drinking-water sources in which gasoline compounds were the second most commonly detected group of compounds following the disinfection by-products, and MTBE was the second most commonly detected VOC (Grady, 2003).

Three solvents were detected in more than 10 percent of samples. The solvent $p$-cresol was detected at all sites. At six of the nine sites it was detected in three or fewer samples, and most of these detections were at concentrations 10 to 100 times less than the LRL for this compound. Perchloroethene (PCE) was detected at three sites, and cis-1,2-DCE was detected only in samples from the White River (table 6). The frequent occurrence of PCE and cis-1,2-DCE predominantly in samples from the White River indicates that the source of these solvents may be a nearby point source.

\section{Comparison to Human-Health Benchmarks}

More than one-half of the compounds detected in source water have a human-health benchmark to which concentrations could be compared. Annual mean concentrations of all compounds at each site were less than human-health benchmarks. Most of the compounds detected were present at concentrations less than $0.1 \mu \mathrm{g} / \mathrm{L}$ (Appendix 1), and only three compounds (atrazine, acetochlor, and dieldrin) had singlesample concentrations greater than their applicable humanhealth benchmark (Appendix 1). BQ values for single samples for all other commonly detected compounds were one to five orders of magnitude less than 1 (figs. 5 and 6). Dieldrin was detected in only one sample, but the measured concentration was two times greater than its benchmark concentration of $0.002 \mu \mathrm{g} / \mathrm{L}$.

Twelve of the 47 most commonly detected compounds have an MCL to which concentrations in samples could be compared. Annual mean concentrations for all of these compounds were less than MCLs. Only simazine and atrazine were detected in samples at concentrations within a factor of 10 or greater than an MCL concentration (fig. 5). Simazine was detected in samples from the Chattahoochee, Elm Fork Trinity, Potomac, and White Rivers at concentrations resulting in a $B Q$ value greater than 0.1 . The maximum annual mean concentration among these stream sites was at the Elm Fork Trinity River. The mean concentration of $0.44 \mu \mathrm{g} / \mathrm{L}$ was about an order of magnitude less than the MCL of $4 \mu \mathrm{g} / \mathrm{L}$. 

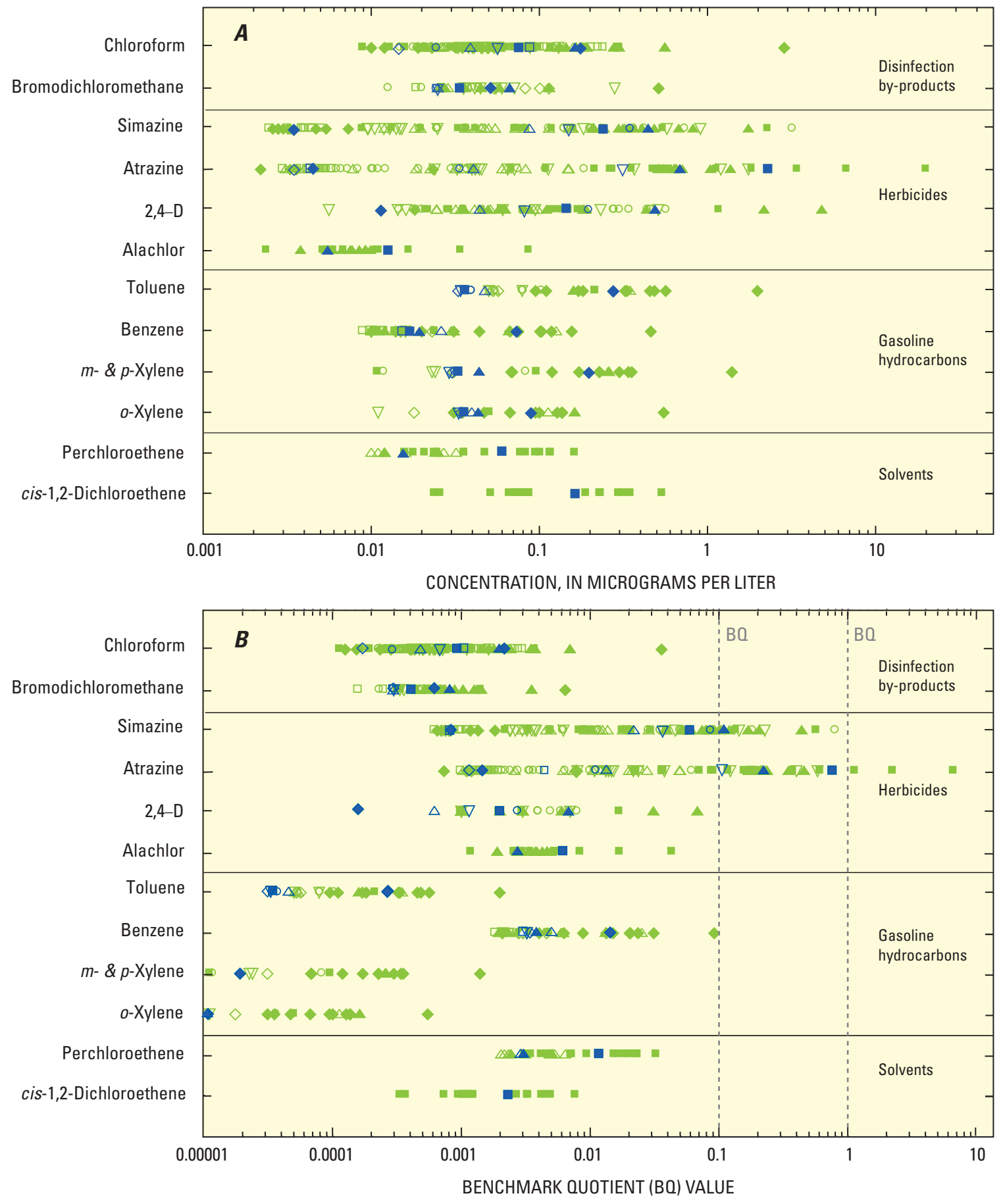

$\begin{array}{llll}\text { - Cache la Poudre River } & \nabla & \text { Potomac River } \\ -\quad \text { Chattahoochee River } & \square & \text { Running Gutter Brook } \\ & \text { Clackamas River } & \diamond & \text { Truckee River } \\ \Delta \quad \text { Elm Fork Trinity River } & \square & \text { White River } \\ \Delta \quad \text { Neuse River } & & \end{array}$

Single-sample concentrations are in green and annual mean concentrations are in blue
Note: Isomers of xylene are compared to the MCL of 10,000 micrograms per liter for total xylenes, and chloroform and bromodichloromethane are compared to the MCL of 80 micrograms per liter for sum of four trihalomethanes.

$B 0$ values less than 0.00001 are not shown

Figure 5. Annual mean and single-sample concentrations of regulated anthropogenic organic compounds commonly detected in source-water samples collected during the first phase of sampling, October 2002-March 2004, were $A$, usually less than 1 microgram per liter; and $B$, usually less than one-tenth of the Maximum Contaminant Levels (MCLs). 

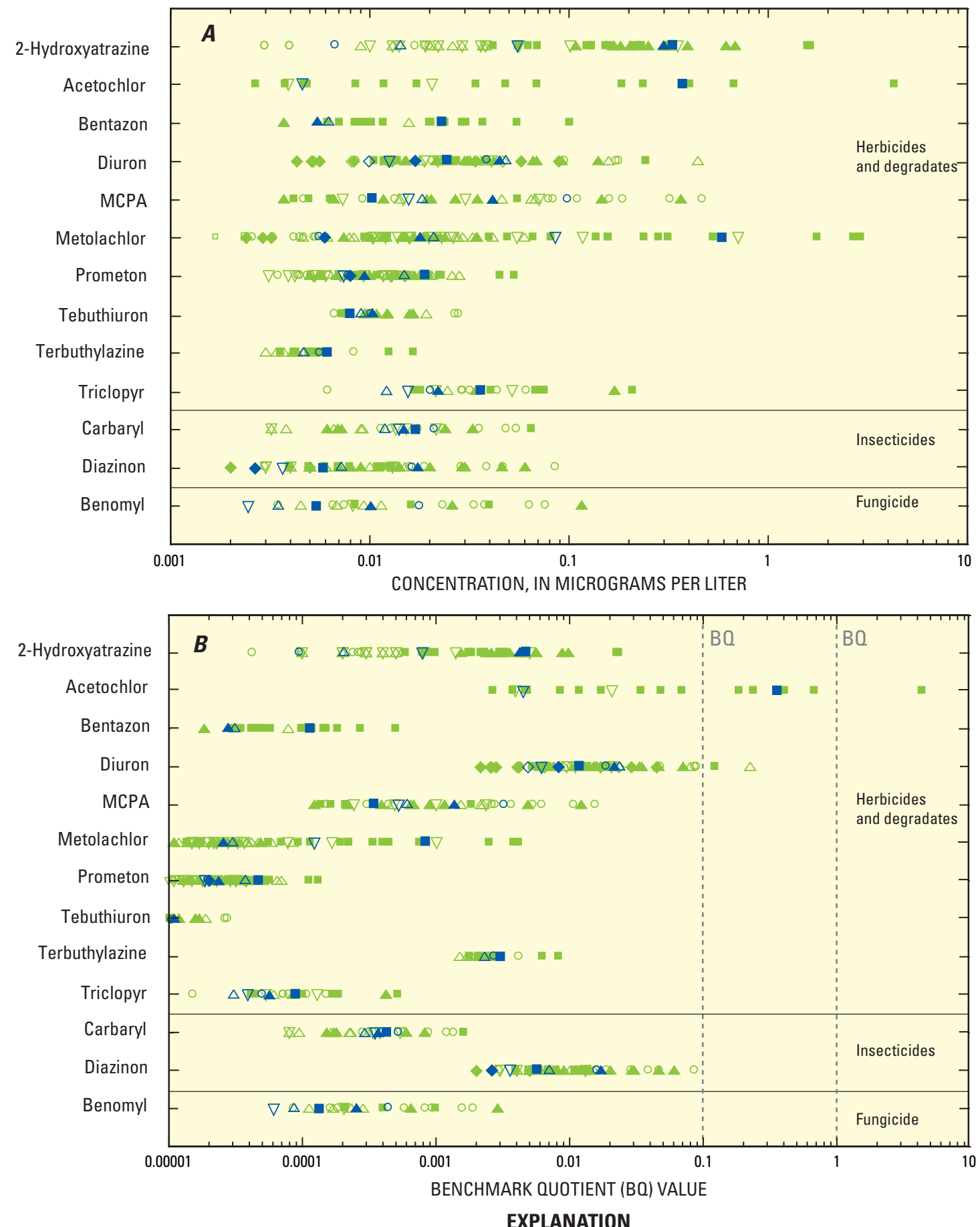

EXPLANATION

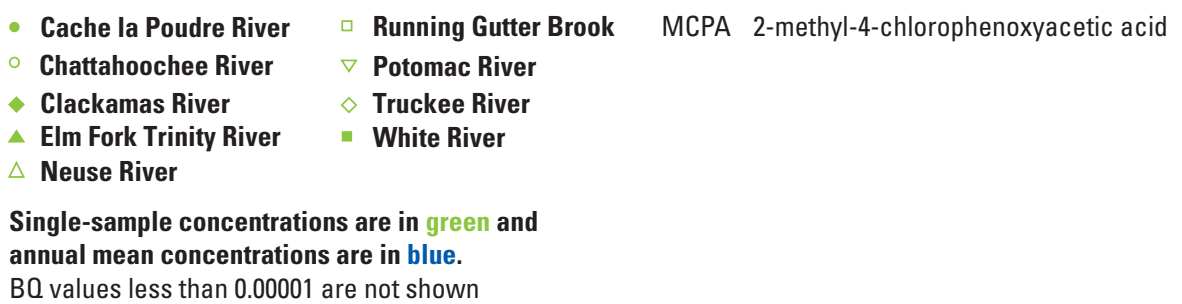

Figure 6. Annual mean and single-sample concentrations of unregulated anthropogenic organic compounds commonly detected in source-water samples collected during the first phase of sampling, October 2002-March 2004, were $A$, usually less than 1 microgram per liter; and $B$, commonly much less than one-tenth of human-health benchmarks. 
Generally, concentrations of atrazine were less than onetenth of the MCL (BQ values less than 0.1) except in the Elm Fork Trinity, Potomac, and White Rivers, which had at least one sample with a BQ value greater than 0.1. Atrazine was detected in three samples from the White River at concentrations greater than its MCL of $3 \mu \mathrm{g} / \mathrm{L}$. These relatively high instantaneous concentrations of atrazine were detected in samples collected during the spring and summer from the White River, where agriculture is the predominant land use in the watershed. The highest atrazine concentration $(20.1 \mu \mathrm{g} / \mathrm{L})$ was in a source-water sample collected during high streamflow conditions in the spring, when peak concentrations of herbicides in streams typically occur and usually for short periods (Gilliom and others, 2006). With the exception of two other samples, single-sample concentrations at other times were less than $3 \mu \mathrm{g} / \mathrm{L}$ (Carter and others, 2007), and the annual mean concentration of atrazine in source water from the White River (October 2002-September 2003) was $2.2 \mu \mathrm{g} / \mathrm{L}$.

Thirteen of the 47 commonly detected unregulated compounds have an HBSL. Annual mean concentrations of all 13 of these compounds were less than their HBSL concentration. Very few samples had individual BQ values greater than 0.1 (fig. 6). Acetochlor was the only compound with a singlesample BQ value greater than 1 . The maximum concentration of acetochlor was $4.32 \mu \mathrm{g} / \mathrm{L}$, which was in the same spring sample as the maximum atrazine concentration from the White River. Other single-sample concentrations were less than the HBSL of $1 \mu \mathrm{g} / \mathrm{L}$ (Carter and others, 2007). The annual mean concentration of acetochlor at the White River from October 2002 through September 2003 was $0.38 \mu \mathrm{g} / \mathrm{L}$, which is about one-third the HBSL for acetochlor.

Twenty-two commonly detected compounds did not have a human-health benchmark for comparison. Of these compounds, $\mathrm{HHCB}$, a fragrance, was the most commonly detected and was present in about one-half of the samples collected. Degradates of atrazine were the second and third most commonly detected compounds without an MCL or HBSL. Concentrations of the atrazine degradates were about equal to or less than atrazine concentrations in most samples. The maximum concentration for a compound without a human-health benchmark was $6.6 \mu \mathrm{g} / \mathrm{L}$ for nonylphenol diethoxylate (total), a compound found in personal-care products.

\section{Mixtures of Compounds}

Contaminants typically co-occur as mixtures, in part, because surface water represents a mixture of water from multiple sources and because different factors may affect each of these sources. Surface water usually is a combination of water derived from overland runoff, upstream reservoir releases, ground-water inflow, and municipal or industrial wastewater discharge. Each of these components in a watershed can be affected by different land uses and activities. Thus, the composition of mixtures in surface (source) water depends on relative proportion of each of these components of flow and the presence of compounds in each of these components.

The potential human-health effects of mixtures of co-occurring organic compounds are largely unknown and have not been extensively studied. The effect of one compound on another's toxicity may be additive, antagonistic (one compound may lessen the effect of another), or synergistic, but much of the growing concern about exposure to mixtures of compounds is related to the potential for synergistic effects (Carpenter and others, 2002). Synergism is when the effect of exposure to a mixture is greater than, or different from, the additive effect of the compounds. Drinking-water standards (MCLs) and other human-health benchmarks generally are based on toxicity data for individual compounds, and the effects of specific mixtures of compounds at low levels are not well understood. With a few exceptions for pesticides with common modes of action, human-health benchmarks generally are not available for specific mixtures. Continued research is needed on potential toxicity of such compound mixtures, and evaluation of the potential effects of mixtures is an increasingly important component of the risk assessment methods used by USEPA, the Agency for Toxic Substances and Disease Registry, and other agencies.

As a first step toward evaluating the potential importance of mixtures of organic compounds to source-water quality, this study used a basic co-occurrence analysis. Although annual mean concentrations and nearly all single-sample concentrations of individual compounds detected were low relative to human-health benchmarks, most samples contained mixtures of two or more compounds (fig. 7). Considering all detections, mixtures of five or more compounds were found in 75 percent of all source-water samples, about 50 percent of the sourcewater samples contained 13 compounds, and 25 percent contained 25 or more compounds (fig. 7). The most frequent contributors to mixtures, not surprisingly, are the compounds that were detected most commonly. These include the herbicides simazine, atrazine and its degradates, metolachlor, and prometon, as well as chloroform and HHCB.

The frequent co-occurrence of multiple organic compounds in source waters as mixtures indicates a need to better understand which specific combinations of compounds occur most frequently and which may be a potential concern for human health. Identification of specific combinations of compounds would provide perspective on patterns of co-occurrence that may be important as more is learned about sources and potential health effects of mixtures. These are important research topics for the future, but are beyond the scope of this report.

\section{Factors that May Affect Source-Water Quality}

Although this study was not designed as a detailed assessment of specific sources and factors affecting the occurrence and concentrations of organic compounds in source 


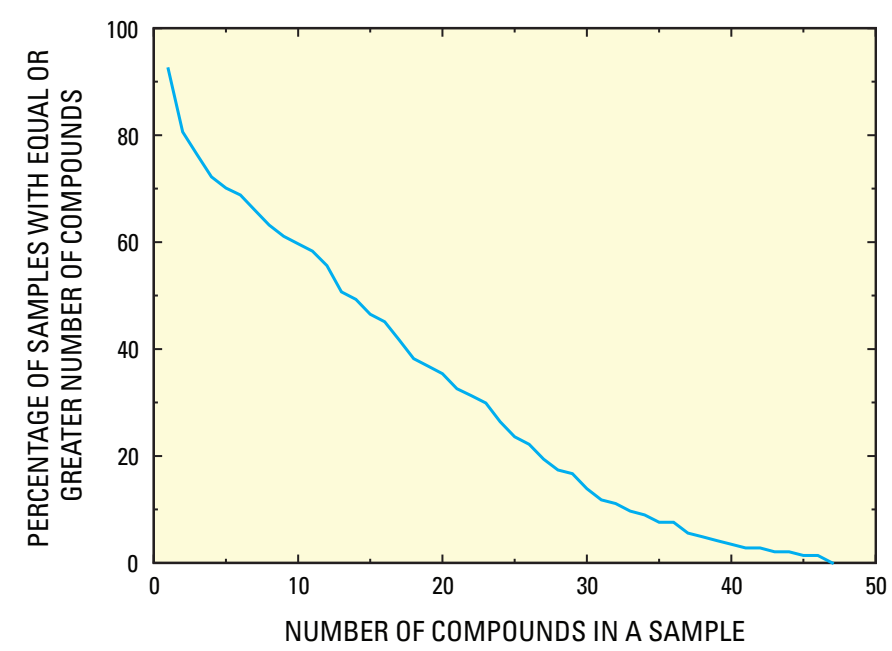

Figure 7. Mixtures of two or more anthropogenic organic compounds analyzed were present in many source-water samples collected during the first phase of sampling, October 2002-March 2004.

waters, evaluation of the characteristics of individual CWSs provides an initial analysis of the general patterns and associations related to land use, wastewater discharge, streamflow, and seasonality. These factors have been found to be associated with the occurrence of organic compounds in other studies (for example, Kolpin and others, 2002, 2004; Gilliom and others, 2006).

\section{Land Use}

The occurrence of particular compounds or combinations of compounds generally follows patterns in watershed land use. Relatively few compounds (10 or fewer) were detected and concentrations were low (less than $0.1 \mu \mathrm{g} / \mathrm{L}$ ) in most samples collected from the Cache la Poudre, Clackamas, and Truckee Rivers and Running Gutter Brook that drain relatively undeveloped watersheds, as compared to the other five streams that drain watersheds with more agricultural and urban areas, where between 9 and 30 compounds were detected (table 1). The median total concentration of all compounds detected in samples from these four streams was less than $0.5 \mu \mathrm{g} / \mathrm{L}$ (fig. 8), whereas the median total concentration for streams with more agricultural and urban land use in the watershed was between 1 and $4 \mu \mathrm{g} / \mathrm{L}$. At least nine compounds were detected in every sample from the Elm Fork Trinity and White Rivers (table 6), where agriculture is the predominant land use in the contributing watersheds (table 1). Many of the compounds commonly detected at these sites were herbicides or herbicide degradates; however, chloroform also was detected in all samples at these sites as well as in all samples from Running Gutter Brook and the Neuse and Potomac Rivers (table 6). The Cache la Poudre River is the only site at which no commonly detected pesticides or pesticide degra- dates were detected (table 6). This site is located in a sparsely populated area on the main stem of the Cache la Poudre River in Colorado, with much of the upstream drainage area included in National Park and National Forest land.

In general, more pesticides were detected at sites with larger amounts of agricultural land use in their contributing watersheds (table 6). The frequency of detection and concentrations at which some herbicides were detected increased as the amount of agricultural land use in the watershed increased, whereas others did not. For example, atrazine was detected at eight of the nine sites, and its detection frequency and concentrations generally increased as the amount of agricultural land use in those watersheds increased (fig. 9). The stream where atrazine was not detected, the Cache la Poudre River, essentially has no agricultural land use in its watershed. In contrast, no clear relation between agricultural land use and the occurrence or concentration of simazine, is evident (fig. 9), likely due, in part, to substantial use of simazine in non-agricultural areas. Thus, as would be expected from use patterns, the amount of agricultural land use alone is not necessarily a good predictor of the potential for detection of a given pesticide.

The relation between the amount of urban land use in the watersheds of the nine sites and the occurrence of compounds that likely would be contributed from urban areas, such as chloroform or MTBE, is not as strong as the relation between agricultural land use and its associated compounds. Many compounds related to urban land use were not detected at enough of the stream sites to evaluate their occurrence with respect to the relative amount of urban land in the contributing watersheds. This result may be due, in part, to the small-scale use of these compounds in urban settings, which tends to cause only local contamination. In addition, the differences in the amount of urban land use in the contributing watersheds

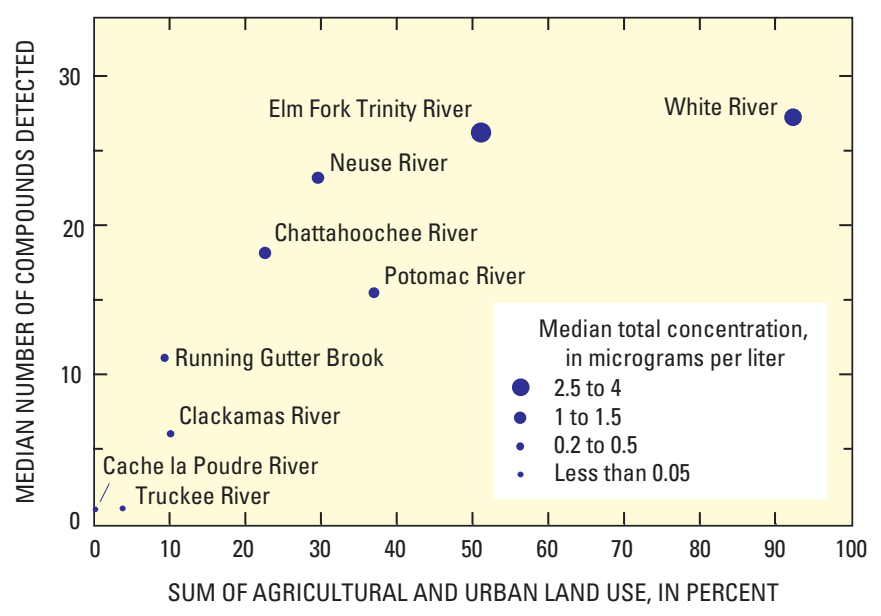

Figure 8. The median number of anthropogenic organic compounds and median total concentration of all compounds detected in source-water samples collected during the first phase of sampling, October 2002-March 2004, for each site generally increased as the sum of agricultural and urban land use in the contributing watersheds increased. 


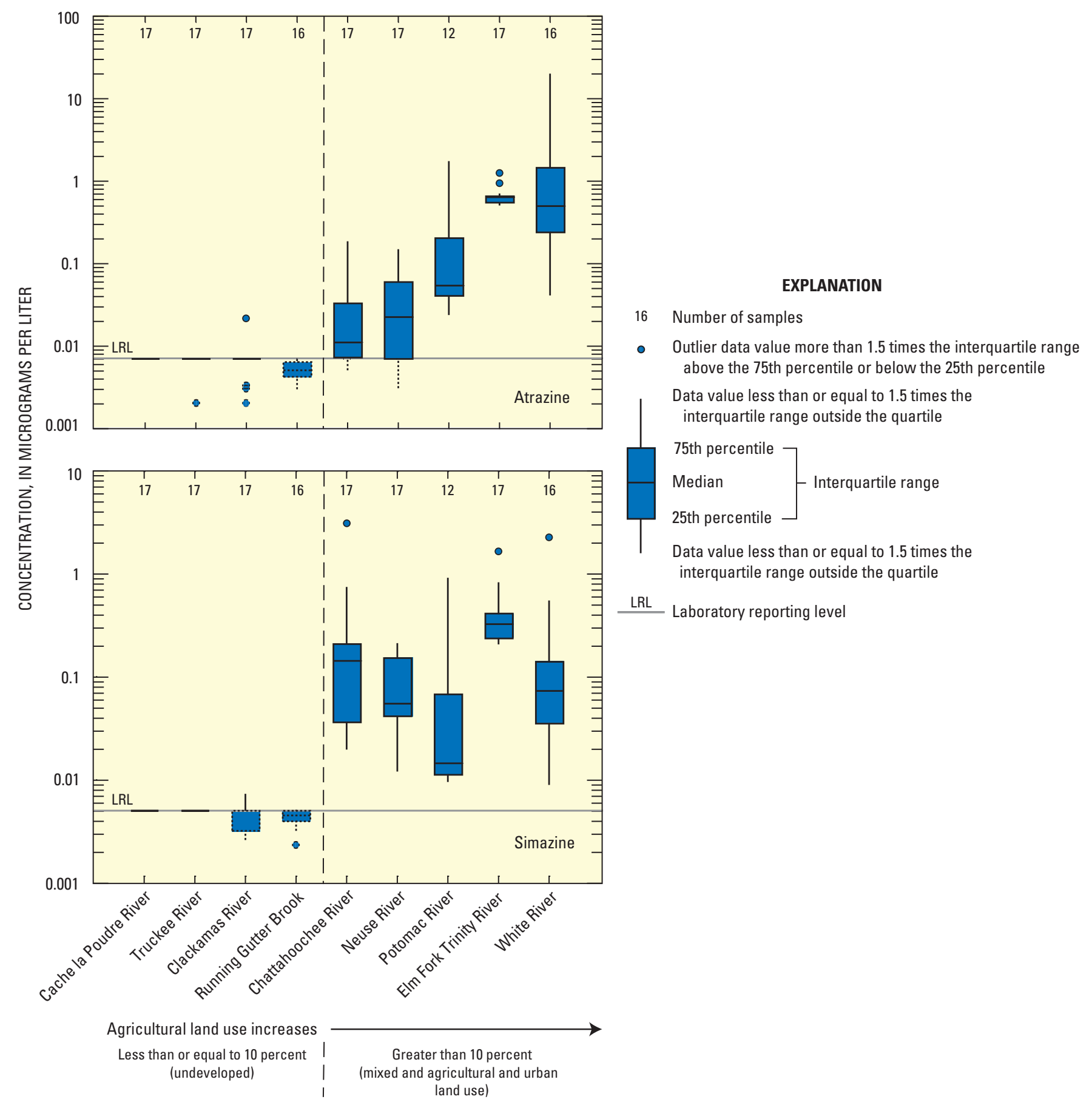

Figure 9. Atrazine concentrations in source-water samples collected during the first phase of sampling, 0ctober 2002-March 2004, generally increased as the amount of agricultural land use in the contributing watersheds increased. The relation between agricultural land use and simazine concentrations was not as strong as that of atrazine likely because of substantial non-agricultural use of simazine. 
of these sites are considerably less than the differences in the amount of agricultural land use (table 1).

\section{Wastewater Discharge}

Compounds in four primary-use groups, including disinfection by-products, manufacturing addititives, personalcare and domestic-use products, and plant- or animal-derived biochemicals, were detected most commonly in samples from the Chattahoochee, Elm Fork Trinity, Neuse, Potomac, and White Rivers. These five watersheds have major municipal wastewater discharges upstream from the sampling locations. For this analysis, the daily mean discharge of major municipal wastewater discharges (those greater than 1 million gallons per day) upstream from the sampling sites within each watershed were summed. This analysis is qualitative because it does not account for minor discharges, the distance between wastewater inputs and the sampling point, or the amount of wastewater as a fraction of total streamflow.

Chloroform and HHCB were the most commonly detected compounds in the disinfection by-product and personal-care and domestic-use groups. The concentration ranges for chloroform and $\mathrm{HHCB}$ are shown in figure 10 by stream site, which are ordered by the mean amount of treated wastewater discharged by major municipal wastewater discharges located within the watershed upstream from the CWS intake (U.S. Environmental Protection Agency, 2006b). Sites on Running Gutter Brook, the Cache la Poudre, Clackamas, and Truckee Rivers have no major wastewater (greater than 1 million gallons per day) inputs upstream from their sampling points.

Three of the four sites without major wastewater inputs had relatively few or no detections of chloroform. Detections of chloroform in every sample from Running Gutter Brook, which does not receive any major wastewater discharge, demonstrate that this compound can have multiple sources, and an understanding of local hydrology and sources of contaminants is needed to fully characterize source-water quality. Chloroform has several possible sources that could be affecting Running Gutter Brook, including chlorinated drinking water (for example, used for lawn or nursery irrigation), septic systems (Ivahnenko and Zogorski, 2006), and also natural sources such as from the formation of chloroform in soils by microbial processes (Laturnus and others, 2002). Detections of the fragrance compound HHCB also were infrequent at the four sites compared to the sites with major wastewater discharges.

Findings indicate associations between the occurrence of some compounds, such as chloroform and HHCB, in source water and upstream wastewater discharges. The occurrence of these compounds in streams that receive major wastewater discharge is consistent with several studies that show that organic compounds, such as pharmaceuticals and personalcare and domestic-use compounds, are not removed during the wastewater-treatment process and are detected in the receiving streams (Halling-Sorensen and others, 1998; Kolpin and others, 2002; Stackelberg and others, 2004).

\section{Streamflow}

For many of the most commonly occurring compounds, a relation between streamflow and concentration is evident at some sites, but not at all sites. For example, atrazine concentrations generally increased with streamflow at the White River site (fig. 11). At several of the other sites where atrazine was detected commonly, however, relatively high concentrations of atrazine occurred during both high and low streamflow conditions. Seasonal use of pesticides such as atrazine likely precludes a strong relation between occurrence and streamflow throughout the year. Although a strong relation between streamflow and atrazine concentration is not indicated at most sites, watershed hydrology can affect the occurrence and concentrations of compounds such as atrazine. For example, at the Elm Fork Trinity River site, which is downstream from a reservoir, the range in atrazine concentrations was considerably less than at other sites where atrazine was detected commonly. Just as a reservoir upstream moderates extremes in streamflow, the range of concentrations of compounds in the water also may be moderated. In addition to a moderating effect on extremes in concentration, reservoirs upstream from these source-water sites also may represent a constant source of some compounds throughout the year, similar to the way in which some compounds are contributed from ground-water or wastewater discharge.

The route by which compounds move through the hydrologic system also is an important factor in whether and how their concentrations change with streamflow. In general, there is an inverse relation between streamflow and concentration for compounds that are contributed to streams principally with ground-water or wastewater discharges. As streamflow increases from surface runoff that contains low concentrations of these compounds, concentrations in source water decrease. For example, concentrations of HHCB, which may be contributed to these streams with wastewater discharge or from failing septic systems, were inversely correlated to streamflow at several of the sites where it was detected (fig. 11).

Many pesticide degradates are formed in the soil zone and subsequently are transported to underlying aquifers and eventually discharged to streams with ground water. An inverse relation at four sites between streamflow and concentrations of the herbicide degradate 3,4-dichloroaniline (fig. 11) indicates that this compound may be contributed to these streams with ground-water discharge, and that concentrations decrease when the proportion of ground water relative to the total streamflow is low in these streams. This type of relation does not exist for all of the degradates analyzed, however, most notably for the degradates of atrazine; their concentrations did not increase when ground water represented a large proportion of streamflow. 


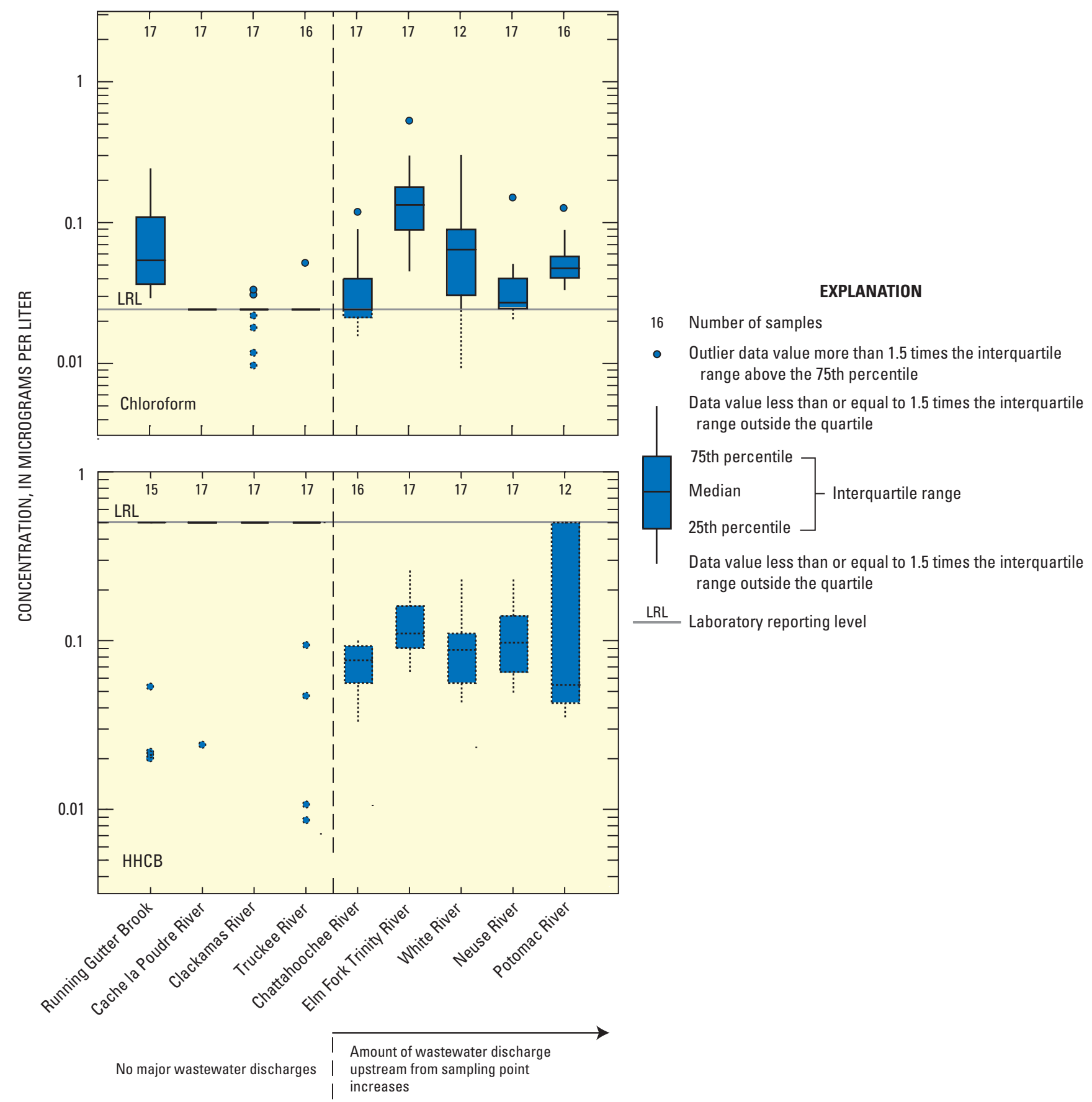

Figure 10. Chloroform and hexahydrohexamethylcyclopentabenzopyran (HHCB) were detected more commonly in source-water samples from watersheds with major wastewater discharges than in samples from watersheds without major discharges during the first phase of sampling, October 2002-March 2004. 

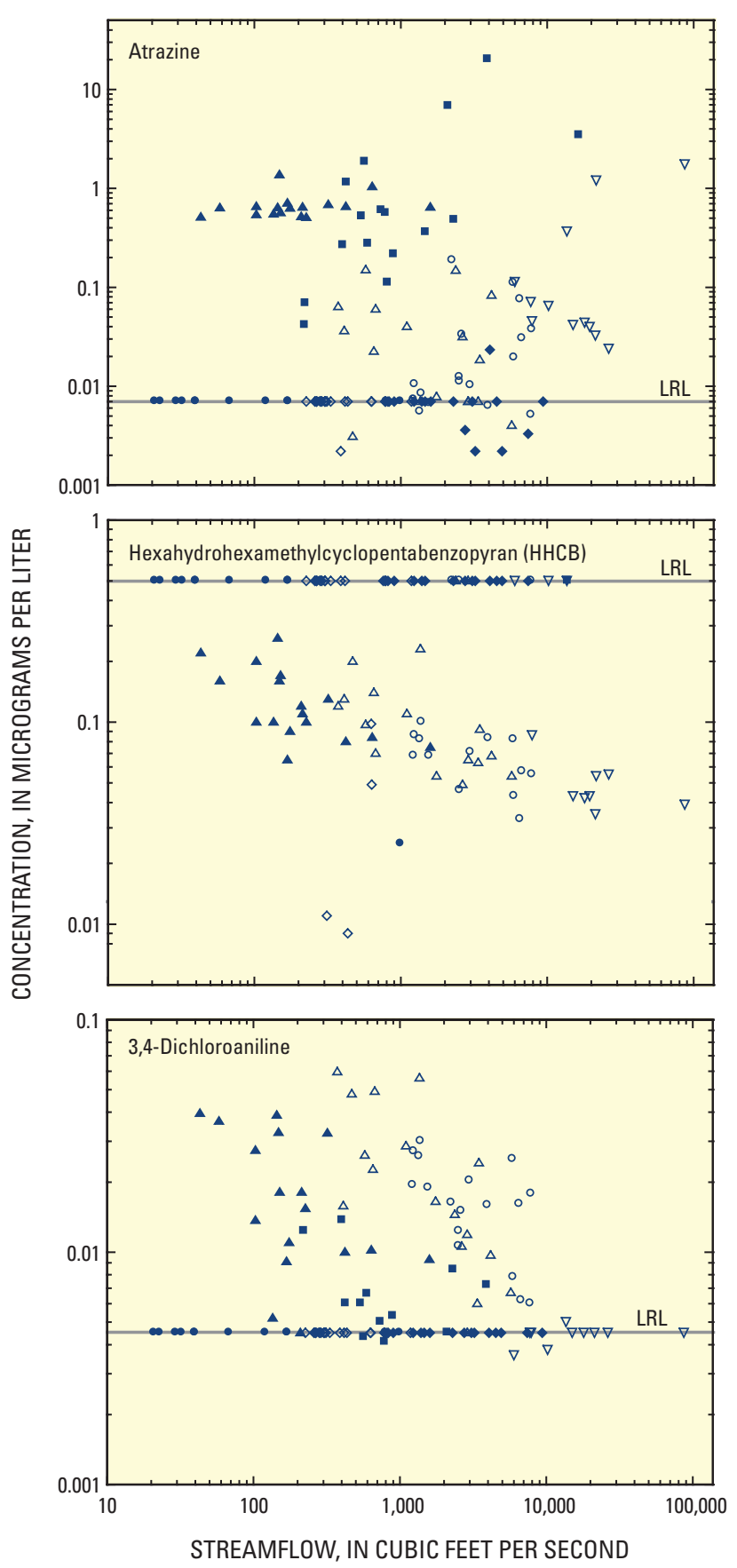

EXPLANATION

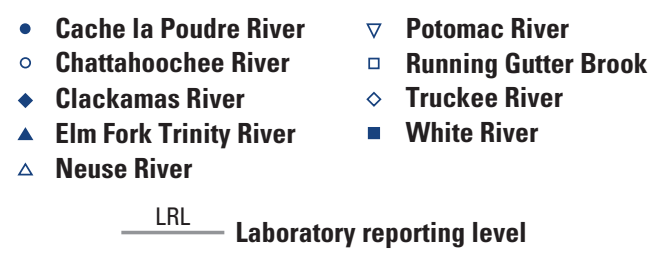

Figure 11. The concentrations of selected commonly detected anthropogenic organic compounds in source-water samples collected during the first phase of sampling, 0 ctober 2002-March 2004, were related to streamflow at some sites, but not at others.

\section{Seasonal Variability}

Relatively few compounds were detected year-round at most sites. The largest number of compounds in all samples throughout the year was 10 compounds in the Elm Fork Trinity River, and 6 of these (chloroform, simazine, atrazine, deethylatrazine, metolachlor, and 2-hydroxyatrazine) were detected year-round at more than one site (table 6). The frequency of detection and the concentrations of compounds throughout the year in streams may be the result of the source of a compound or transport route that it takes to the stream. For example, wastewater discharge may be a relatively constant source of some compounds such as chloroform or HHCB. For some compounds, including the herbicides that were detected throughout the year and cis-1,2-DCE, ground-water discharge during base-flow conditions may contain measurable concentrations of these compounds. Other compounds may be detected only for short periods of time after they are used.

Herbicides and their degradates had the most pronounced seasonal change in occurrence and total concentration (fig. 12), and had the largest number of compounds detected throughout the year. The amount and timing of change in total herbicide concentration varied among the sites. The largest changes in total herbicide concentrations occurred in the Chattahoochee, Potomac, and White Rivers, where the total concentration of herbicides varied by at least tenfold during the year. Smaller amounts of change occurred in Running Gutter Brook and the Neuse and Elm Fork Trinity Rivers. At several of the stream sites, high concentrations were associated with high streamflow, likely the result of runoff following storms after application times. Other studies have shown that high runoff following seasonal applications of herbicides results in the highest concentrations of the year (for example, Gilliom and others, 2006). At two sites, the Potomac and White Rivers, total herbicide concentrations increased with the addition of the chloroacetanilide herbicide degradates that were detected, but the concentration profile generally did not change (fig. 12). The other site at which these additional compounds were analyzed was the Neuse River, and only one of these degradates was detected in one sample.

The timing of changes in total herbicide concentration also varied among the sites. At the Neuse, Potomac, and White Rivers, higher concentrations occurred during the spring and summer compared to other times of the year (fig. 12). In contrast, peak concentrations at the Running Gutter Brook and the Chattahoochee and Elm Fork Trinity Rivers occurred in the fall or winter. However, in the Chattahoochee River, total herbicide concentrations also were high during the growing season.

Where several herbicides were detected at a site, the concentration profiles throughout the year typically were similar, but differences in when herbicides are applied and whether they are used in urban areas result in some differences in occurrence (fig. 13). For example, simazine and atrazine generally had similar concentration profiles for both the 


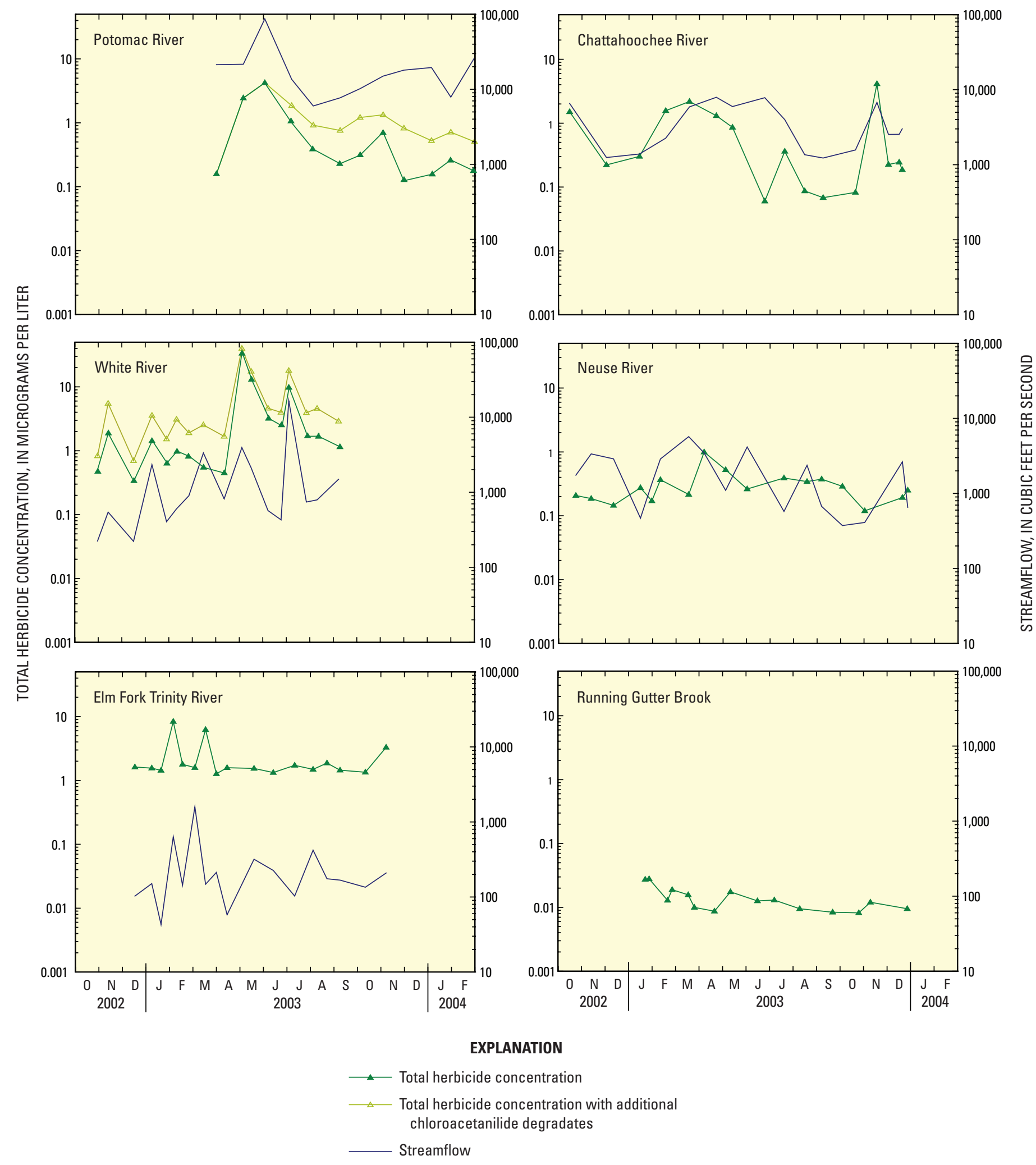

Figure 12. Total herbicide concentrations in source-water samples collected during the first phase of sampling, 0ctober 2002-March 2004, varied seasonally at most sites. 


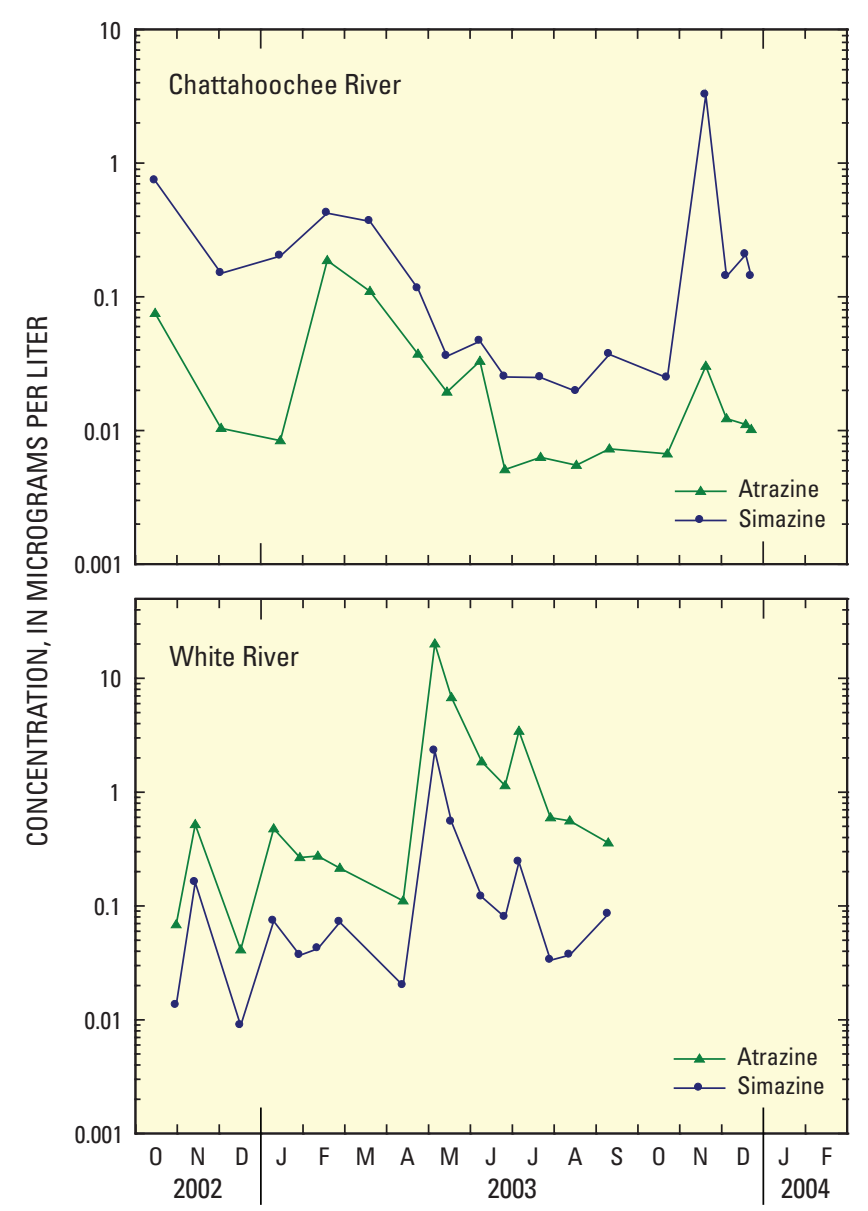

Figure 13. Seasonal variation in atrazine and simazine concentrations differed for samples collected from the Chattahoochee and White Rivers during the first phase of sampling, October 2002-March 2004.

Chattahoochee and White Rivers, but the maximum concentration of simazine at the Chattahoochee River was in November, whereas the maximum atrazine concentration occurred in late February. This large increase in simazine concentration in the fall compared to atrazine likely is a result of urban uses of simazine in the Chattahoochee River watershed. An increase in simazine concentrations during the fall has been observed in other streams with urban and suburban land use and may be the result of the use of pre-emergent herbicides on lawns during the fall and winter for the control of winter weeds (Frick and others, 1998; Gilliom and others, 2006). Concentration profiles of atrazine and simazine also were similar at the White River; however, a small increase in simazine concentrations in September and October also occurred at the White River. The timing of peak concentrations of both herbicides likely differed at the two sites because of when these herbicides are applied.

\section{Comparisons of Selected Organic Compounds in Source Water and Finished Water Sampled in 2004 and 2005}

The secondary purpose of this report is to provide comparisons of selected compounds in source water with their occurrence in finished water (water that has passed through treatment processes but prior to distribution). Samples of source and finished water were collected during 2004-05 at eight of the nine CWSs. Because relatively few compounds were detected in samples from the Cache la Poudre River during the first phase of sampling, this site was not sampled during the second phase.

Monitoring during the second phase of the study generally focused on analytical suites that included compounds found to occur most commonly in source water during the 2002-04 monitoring. The number of samples collected at each of the sites, therefore, was smaller during the second phase of sampling, and not all samples were analyzed for the 258 compounds that were analyzed in most source-water samples collected during the first phase. As a result of these differences and the more targeted sampling in the second phase, detection frequencies of compounds in source water would be expected to be greater than in the first phase of sampling. Additionally, differences in streamflow or changes in chemical use in a watershed between sampling phases may affect the occurrence of some compounds.

Finished-water samples were collected after treatment at each of the CWSs, and time was allowed between collection of the source- and finished-water samples to account for the retention time in the treatment plant (table 7). Retention time was determined through individual contact with treatment plant operators at each CWS. At some of the sites, the amount of time between collection of the two types of samples was varied to account for changes in retention time that result from changes in water demand. At other sites, finished-water samples were collected at fixed intervals after the sourcewater samples were collected, which generally represented an average retention time. Two CWSs intermittently blend ground water from wells with the surface-water source. The CWS on Running Gutter Brook augments the surface-water supply with ground water after treatment, and the CWS on the White River uses ground water intermittently to meet demand during peak use. Some differences between sourceand finished-water quality might be attributable to changes in source-water quality that are not represented by the finishedwater sample, particularly for sites where water was blended with other sources or where the same amount of time between samples was used for all samples. Other factors also may affect differences in occurrence between source- and finishedwater samples that may not be attributed entirely to treatment, including the inadvertent addition of compounds in finished water from pipes and other plumbing, treatment-plant mainte- 
Table 7. Length of time between collection of source- and finished-water samples during the second phase of sampling, June 2004-August 2005.

\begin{tabular}{lc}
\hline \multicolumn{1}{c}{ Stream site } & $\begin{array}{c}\text { Time between collection } \\
\text { of surface- and finished- } \\
\text { water samples }\end{array}$ \\
\hline Chattahoochee River, Georgia & 5 hours \\
Clackamas River, Oregon & 1 hour \\
Elm Fork Trinity River, Texas & 2 hours \\
Neuse River, North Carolina & 2 to 5 days \\
Potomac River, Maryland & 2 days \\
Running Gutter Brook, Massachusetts & 1 to 3 days \\
Truckee River, Nevada & 4 hours \\
White River, Indiana & 8 to 18 hours \\
\hline
\end{tabular}

nance, and potential analytical variability associated with low concentrations at or near LRLs.

The sampling design and resulting comparisons between source- and finished-water samples were not intended to characterize treatment efficacy, which would require precise timing of sampling at different stages of water treatment. In general, the types of treatment used by the CWSs that were sampled in this study were not specifically designed to remove most of the organic compounds monitored. For example, five of the eight CWSs used conventional water treatment, consisting of coagulation, flocculation, sedimentation, filtration, and disinfection. The other three CWSs used other types of treatment (table 2). Results for the compounds monitored in this study represent an initial assessment of whether compounds present in source water also are present in the associated finished water.

Finished-water samples were "quenched" with ascorbic acid at the time of collection to scavenge the free chlorine that might react with any compounds present in the sample. Therefore, finished-water data are not necessarily representative of drinking-water quality at the tap because additional contact time with disinfectants in the distribution system may change concentrations of some of the constituents detected in the finished water at the sample collection point. Some compounds may be transformed or degraded, whereas others such as disinfection by-products may continue to form in the distribution system.

\section{Commonly Detected Compounds}

In general, compounds that were detected commonly in source water during the first sampling phase (defined as detected in more than 10 percent of samples) also were detected commonly during the second phase of sampling, and at relatively similar detection frequencies. One notable exception was diazinon, which was detected in more than 40 percent of the samples during the first phase of sampling and in only about 20 percent during the second phase. This reduced frequency of detection may be the result of the phase out of residential uses of diazinon on December 31, 2004 (U.S. Environmental Protection Agency, 2008b). Four compounds (1,2,4-trimethylbenzene, tert-butyl alcohol, tebuthiruon, and beta-stigmastanol) detected commonly in source water during the first phase of sampling were detected in less than 10 percent of source- or finished-water samples or were not detected during the second phase of sampling.

About two thirds (27) of the compounds detected commonly in source water (not including degradates of chloroacetanilide herbicides) during June 2004-August 2005 also were commonly detected in finished water, and for many of these compounds at about the same frequency (fig. 14). Of the remaining 15 compounds detected commonly in source water, the detection frequency in finished water was one-half or less than the detection frequency in source water. Eleven compounds were detected commonly in finished water and were either not detected in source water or had a detection frequency in source water no more than one-half the detection frequency in finished water. Detection frequencies of all compounds detected in source or finished water are summarized in Appendix 2; however, the discussion of results in this section of the report focuses on the 53 compounds that were detected commonly (in 10 percent of source- or finished-water samples) in the second phase of sampling (fig. 14) because relatively little can be inferred about patterns of occurrence in source and finished water from compounds that were detected at low concentrations in only a few samples.

\section{Compounds Detected More Commonly in Source Water than in Finished Water}

Fifteen of the 53 commonly detected compounds had a detection frequency in finished water that was about one-half or less than the detection frequency in source water (fig. 14). Smaller detection frequencies in finished water may indicate a decrease in concentration below the LRLs of compounds during water treatment as a result of transformation, volatilization, sorption, or sedimentation.

Four compounds-3,4-dichloroaniline (an herbicide degradate), diazinon and fipronil (insecticides), and fipronil sulfone (the degradate of fipronil) — were detected commonly in source water but were not detected or were detected in 2 percent or less of the associated finished-water samples (fig. 14). The degradation of organophosphate insecticides such as diazinon has been observed in studies of the effect of chlorination on pesticides (Magara and others, 1994). Diazoxon (diazinon oxygen analog), which is the principal degradate formed as a result of the oxidation of diazinon during chlorination (Aizawa and others, 1994), was detected in one finished-water sample in this study; however, because most of the measured concentrations of diazinon in source water were less than the LRL for diazoxon, detection of this degradate 


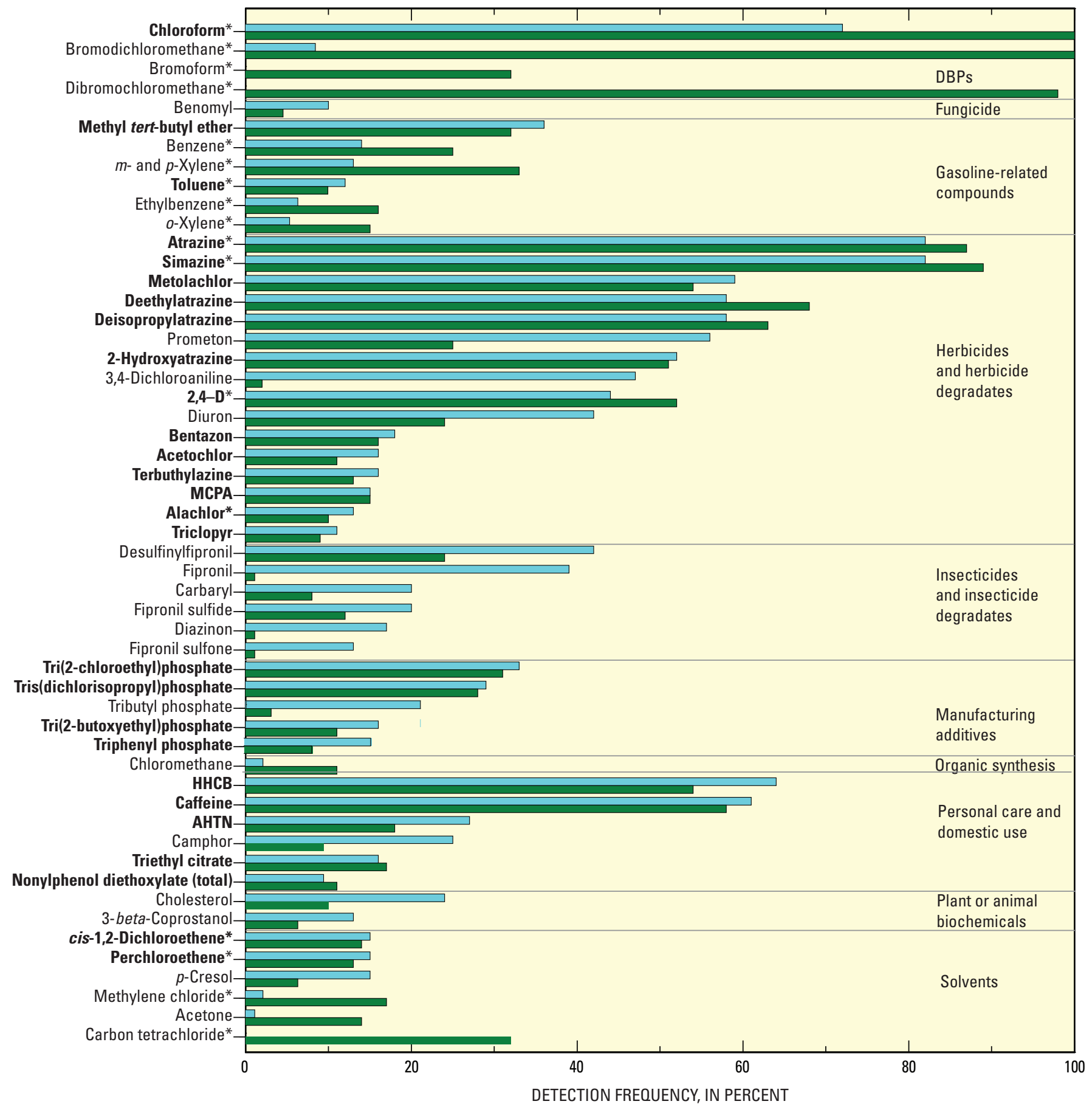

DETECTION FREQUENCY, IN PERCENT

\section{EXPLANATION}

Source water

Finished water

* Regulated compound

DBP Disinfection by-product

Figure 14. Many commonly detected anthropogenic organic compounds generally had similar detection frequencies in sourceand finished-water samples collected during the second phase of sampling, June 2004-August 2005 (using no common assessment level).
MCPA 2-methyl-4-chlorophenoxyacetic acid

HHCB Hexahydrohexamethylcyclopentabenzopyran

AHTN Acetyl hexamethyl tetrahydronaphthalene Note: compound names in bold were detected commonly in source water and had a similar detection frequency in finished water 
would be unlikely even if it was produced. Other organophosphate insecticides, such as chlorpyrifos and malathion, were detected infrequently in source water and were not detected in corresponding finished-water samples, although malathion was detected in one finished-water sample without a corresponding source-water detection. These results are similar to results for organophosphate pesticides in source- and finishedwater samples reported by Coupe and Blomquist (2004).

The compounds 3,4-dichloroaniline, fipronil, and fipronil sulfone are not organophosphates, but results for these compounds were similar to the those for organophosphate pesticides in that they generally were not detected in finished-water samples. The quality-assurance plan for this study included paired finished-water spike samples; one was quenched (with dechlorination reagents) and the other was not quenched. These three compounds were not detected in spike samples that did not have ascorbic acid added to quench free chlorine but were present in spike samples with ascorbic acid added, indicating that transformation of these compounds is related to chlorination (Valder and others, 2008). One other group of compounds that was not detected commonly in source water but appeared to be transformed or removed during water treatment were aromatic hydrocarbons with one or more methyl groups, such as 1,3,5-trimethylbenzene (a gasoline hydrocarbon, Appendix 2).

Eleven compounds had detection frequencies in finished water that were about one-half the detection frequency in source water (fig. 14). The decreases in detection frequency of diuron, desulfinylfipronil, fipronil sulfide, and $p$-cresol may be, in part, a result of the disinfection process. Qualityassurance data for unquenched spike samples compared to quenched spike samples indicated generally lower recoveries of these compounds in unquenched spikes (Valder and others, 2008). Benomyl, prometon, carbaryl, tributyl phosphate, camphor, cholesterol, and 3-beta-coprostanol also were detected more commonly in source water than in finished water, but spike data do not indicate that concentrations are affected by chlorination; recoveries generally were similar for quenched and unquenched spikes. Seasonal use of PAC to treat for taste- and odor-compounds at several of the water-treatment plants or other differences in water-treatment processes also could be factors in smaller detection frequencies in finished water for all of these compounds.

\section{Compounds Detected More Commonly in Finished Water than in Source Water}

Eleven of the 53 commonly detected compounds had a detection frequency in finished water that was about two or more times greater than the detection frequency in source water or were not detected at all in source water (fig. 14). A higher detection frequency in finished water compared to source water could result from the formation of a compound during water treatment, sample-collection timing issues, analytical error at concentrations near the LRL, addition of a compound as a result of blending with other source water, chemicals used during water treatment, pipes and other plumbing, or use of the compounds in the water-treatment plant (sample contamination). Identification of all of the potential sources of compounds and determination of their effect on finished-water quality were beyond the scope of this study.

The formation of trihalomethanes as a result of the chlorination of drinking water is well documented (Rook, 1974). In this study, chloroform was detected at low concentrations in most source-water samples; however, chloroform was detected in all finished-water samples at concentrations from 10 to 100 times greater in finished-water samples than in source-water samples. All finished-water concentrations of chloroform were less than the MCL for the trihalomethanes. Bromoform, dibromochloromethane, and bromodichloromethane were not detected or were detected infrequently in source-water samples but were detected in 32 to 100 percent of the finished-water samples (Appendix 2).

In addition to the disinfection by-products, several other compounds were detected in the finished water more commonly than in source water. These compounds generally were detected in samples from a few of the water-treatment plants, and most of these compounds were not detected commonly in source water. Acetone and methylene chloride were detected in finished-water samples collected at two and five of the CWSs, respectively. These solvents commonly are used in laboratory settings as cleaning agents (degreasing) and for chemical extractions. The occurrence of these compounds at low concentrations predominantly in finished water at these sites may reflect use of these VOCs at the water-treatment plants. Carbon tetrachloride was not detected in any sourcewater samples, but was present in 32 percent of the finishedwater samples (Appendix 2). The source of these low-level detections in finished-water samples is not known, but the carbon tetrachloride in the finished water may be a contaminant in the chlorine used for disinfection (Christman, 1980), or possibly a disinfection by-product (Krasner and others, 2006).

Another example of the occurrence of compounds in finished water that were not present in the source water occurred at one treatment plant following routine maintenance that included painting of a clear well storage tank (Erik Staub, U.S. Geological Survey, written commun., 2007). Several hydrocarbons, including benzene, ethylbenzene, and isomers of xylene (fig. 14), were detected in finished-water samples following the painting, and concentrations of these compounds decreased in subsequent samples.

\section{Changes in Concentration}

The comparison of concentrations of organic compounds in source and finished water provides a preliminary perspective on the potential significance of the occurrence of compounds in source water to finished-water quality. However, the relatively low concentrations $(0.1 \mu \mathrm{g} / \mathrm{L}$ or less $)$ at which most compounds were detected limit the comparison 
of changes in concentration from source to finished water. A small change in absolute concentration of a compound, for example a decrease from 0.05 to $0.03 \mu \mathrm{g} / \mathrm{L}$ from source to finished water, is relatively large on a percentage basis but may be the result of analytical variability, sample timing issues, or may reflect a true decrease. Because of these uncertainties, changes in concentration of commonly detected compounds generally were categorized as small, moderate, or large, reflecting finished-water concentrations that were less than 25 percent, between 25 and 75 percent, and more than 75 percent of the source-water concentration. It also is important to note that, in general, conventional water treatment and most of the treatment steps used by the CWSs sampled are not specifically designed to treat for the organic compounds detected in this study. However, CWSs may use additional treatment steps if source water is known to contain compounds with concentrations near or greater than an MCL.

Although the water-treatment steps differ among the eight CWSs, the amount of change in concentration of organic compounds from source- to finished-water samples generally did not differ systematically at a CWS or among the CWSs for the 27 commonly detected compounds in source water where the detection frequency was similar to that in finished water. For example, when atrazine was detected in source water, it typically was detected in the associated finished water at all of the CWSs at a concentration within 50 percent of the source-water concentration (fig. 15A). Finished-water atrazine concentrations were significantly lower (p-value less than 0.05; Wilcoxon signed rank test; Helsel and Hirsch, 1992) than source-water atrazine concentrations at three of the CWSs (Elm Fork Trinity, Neuse, and White Rivers), but the average amount of change in atrazine concentrations in most sample pairs from these three CWSs was less than 25 percent. The degradates of metolachlor, alachlor, and acetochlor were not analyzed at all sites, but results for these compounds generally were similar to those for atrazine in that finished-water concentrations generally were within 75 percent of sourcewater concentrations where these compounds were analyzed (Appendix 2).

A total of 15 compounds commonly detected (in more than 10 percent of all samples) in source water generally had moderate to large changes in concentration from source to finished water. Four of these-fipronil (fig. 15B), fipronil sulfone, diazinon, and 3,4-dichloroaniline-usually were not detected in finished water although they were present in the associated source-water sample. A few compounds that were detected in less than 10 percent of source-water samples, primarily organophosphate insecticides (for example, malathion, and chlorpyrifos) and aromatic hydrocarbons with one or more methyl groups (for example, 1,3,5-trimethylbenzene) either were not detected in finished-water samples or were detected at lower concentrations than in the associated sourcewater sample (Appendix 2).

Diuron was detected in source water from five of the eight sites, and in most sample pairs, concentrations were lower or diuron was not detected in finished water (fig. 15C); however, the amount of change in concentration varied among and within the CWSs. For example, diuron was detected in source water at five sites, but at the Neuse and White Rivers, it was not detected in the associated finished-water sample. At other sites, diuron was detected in both source and finished water in most samples and concentrations generally were somewhat lower in finished water. However, most of the concentrations were near the LRL and although it appears that diuron concentrations were affected by water treatment, particularly at two sites that use PAC, the results are not conclusive. These results for diuron and 10 additional compounds, such as benomyl, carbaryl, and cholesterol, indicate that concentrations of these compounds may be reduced as a result of treatment at the CWSs, but additional information is needed to better understand the factors that are affecting the occurrence of these compounds.

For most compounds without large changes in concentration from source to finished water, for example atrazine, changes in source-water concentrations during the year generally were reflected in the associated finished water. Few compounds were detected at most sites, so atrazine is used as an example of how concentrations varied over time in source and finished water (fig. 16). Atrazine was detected infrequently in source-water samples from the Clackamas and Truckee Rivers and these sites are not included in figure 16. At most sites, changes in atrazine concentrations in source water were reflected in the associated finished water.

Concentrations of atrazine in source- and finished-water samples did not differ by more than 25 percent for most samples from the Chattahoochee and Potomac River, and Running Gutter Brook sites (fig. 16); however, some differences between source water and finished water were observed. At the Chattahoochee River site, the concentration profile of atrazine in finished water appears to lag behind that of source water following increasing concentrations. The delay in higher finished-water concentrations relative to source-water concentrations may be the result of a mismatch in timing of source- and finished-water sample collection, or could represent adsorption-desorption of atrazine to and from anthracite filters used in the treatment process, similar to observations of Richards and others (1975). Concentrations of atrazine in source and finished water at the CWS at Running Gutter Brook were less than $0.01 \mu \mathrm{g} / \mathrm{L}$ (fig. 14). This CWS uses slow sand filtration, and little information is available about the fate of pesticides and other organic contaminants during slow sand filtration. At Running Gutter Brook, any periodic blending of the source waters did not result in appreciable changes in atrazine concentrations.

Several of the CWSs use PAC in varying amounts to remove taste- and odor-compounds during parts of the year. In addition to controlling taste- and odor-compounds, use of PAC has been shown to decrease concentrations of several organic compounds including atrazine in source water (Miltner and others, 1989; Duguet and others, 1994; Westerhoff and others, 2005). The seasonal use of PAC may help explain the observed pattern at the Neuse River site, where source- and 

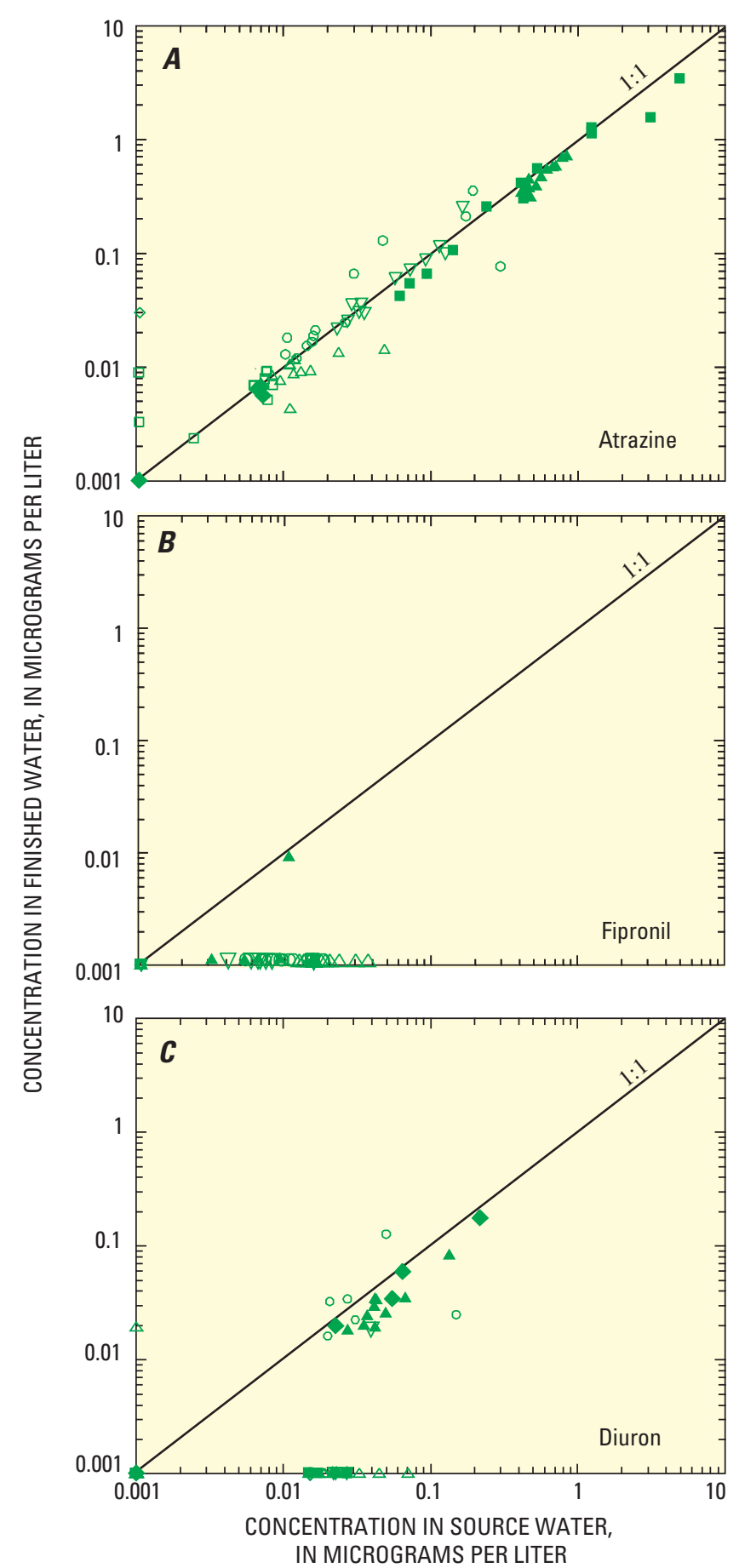

EXPLANATION

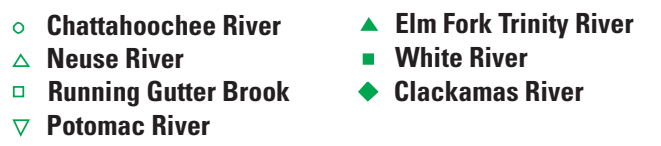

Note: Nondetections were set to 0.001 microgram per liter

Figure 15. Concentrations of selected anthropogenic organic compounds in samples collected during the second phase of sampling, June 2004-August 2005, showed $A$, small (atrazine); $B$, large (fipronil); and $C$, moderate (diuron) amounts of change from source to finished water. finished-water concentrations of atrazine were similar for samples from July to December of 2004 (fig. 16). In samples collected between February and May 2005, however, concentrations of atrazine in finished water were substantially lower than those in source water, which could be the result of the seasonal use of PAC. The relative decrease in atrazine concentrations varied at this CWS, and differences in the decrease could be related to several factors. The efficacy of PAC can be affected by the dose, contact time, and amount and type of natural organic matter in the source water (Duguet and others, 1994; Snyder and others, 2003).

Concentrations of atrazine were lower in finished water than in source water in all sample pairs from the Elm Fork Trinity River site and in most sample pairs collected from the White River site (fig. 16). The Elm Fork Trinity River CWS uses ozone as a preliminary water-treatment step (table 2), which has been shown to reduce concentrations of atrazine in drinking water, with deethylatrazine identified as one of the principal by-products (Adams and Randtke, 1992; Verstraeten and others, 2002). Deethylatrazine concentrations at this site were higher in finished-water than in source-water samples (data not shown). Generally, atrazine concentrations in finished water were lower than in source water at the White River CWS. Some of the difference in concentration may be related to the use of PAC during parts of the year as well as intermittent blending of surface water with ground water to supplement supply.

These results for atrazine highlight the need to monitor and characterize the quality of source water used for drinking water. Understanding how compounds move through the hydrologic system and the factors that affect their occurrence can contribute to the effective management of drinking-water quality. In addition, characterizing the occurrence of the compounds not typically analyzed in finished water may lead to the development of treatment technologies for their removal.

\section{Comparison to Human-Health Benchmarks}

Annual mean concentrations of all compounds detected in finished water were less than their human-health benchmarks. More than one-half of the most commonly detected compounds have a human-health benchmark for comparison. Annual mean concentrations for most of the commonly detected compounds were two to five orders of magnitude less than their human-health benchmarks (fig. 17A). Two disinfection by-products had annual mean concentrations within a factor of 10 (BQ greater than 0.1) of the MCL for total trihalomethanes (fig. 17A). Chloroform was present in finished water at all CWSs with annual mean BQ values between 0.1 and 0.3 . Annual mean concentrations for bromodichloromethane were within a factor of 10 of the MCL at three CWSs. Concentrations of bromoform and dibromochloromethane were considerably less than chloroform, and at all of the CWSs the annual mean of the sum of these disinfec- 

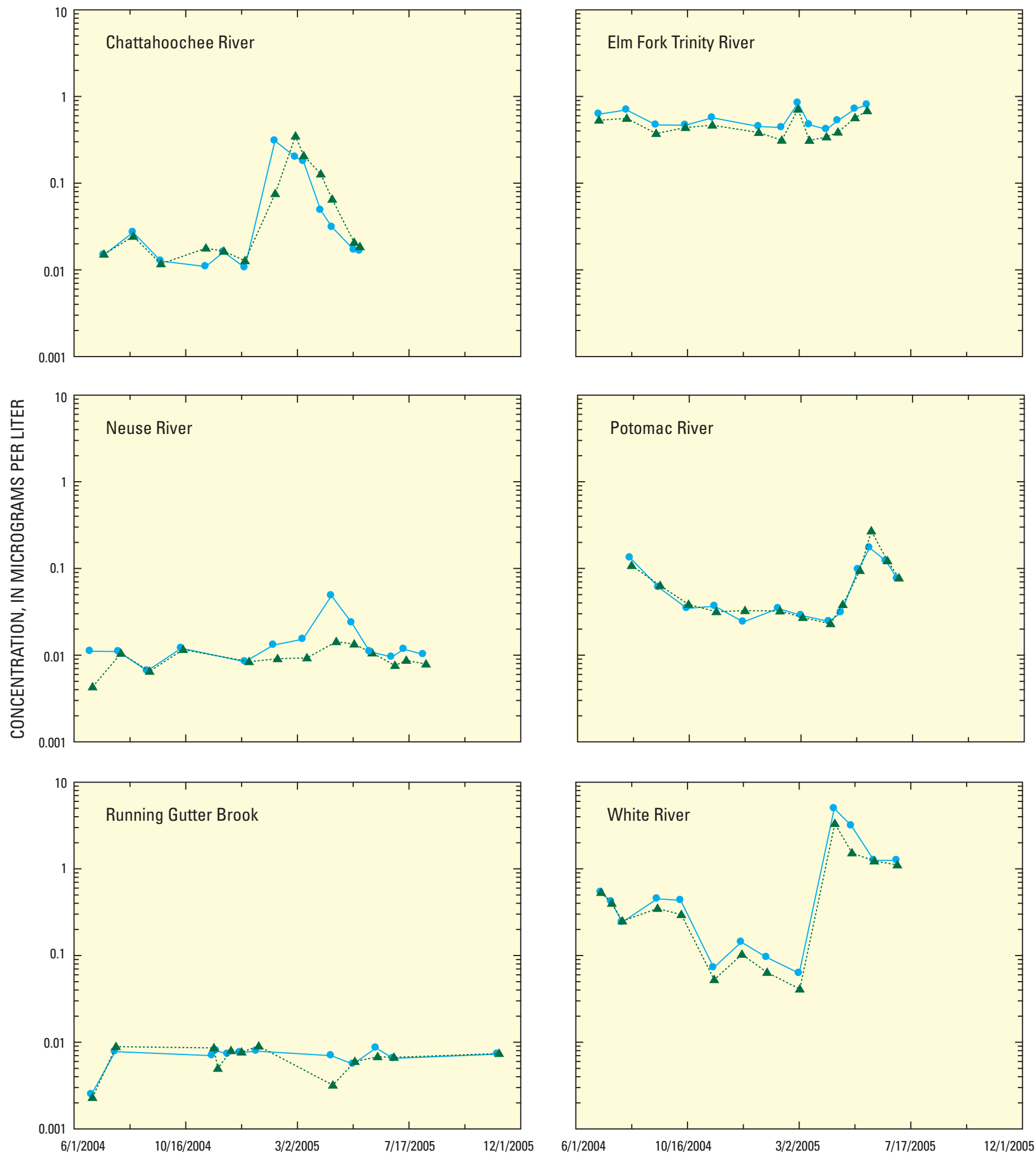

EXPLANATION

$\longrightarrow$ Source water $\quad \cdots \cdots \cdots \cdots$......... Finished water

Figure 16. Changes in atrazine concentrations in source water usually were reflected in the finished-water quality in samples collected at six sites during the second phase of sampling, June 2004-August 2005. 

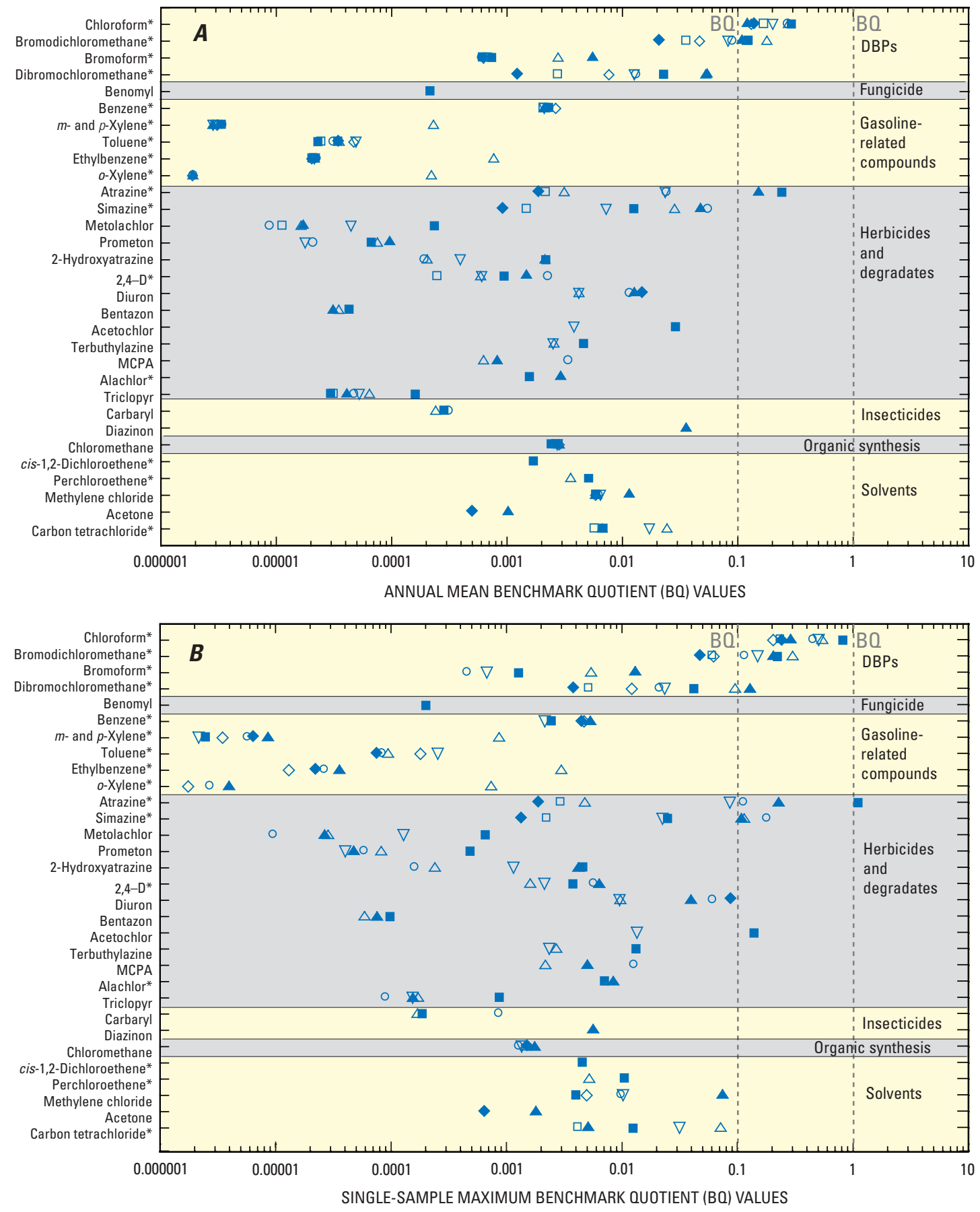

\begin{tabular}{llllll} 
& & \multicolumn{2}{c}{ EXPLANATION } & \\
$\circ$ & Chattahootchee River & $\nabla$ & Potomac River & $*$ & Regulated compound \\
$\Delta$ & Neuse River & $\Delta$ & Elm Fork Trinity River & DBP & Disinfection by-product \\
$\square$ & Running Gutter Brook & $\square$ & White River & MCPA & 2-methyl-4-chlorophenoxyacetic acid \\
$\diamond$ & Truckee River & - & Clackamas River & &
\end{tabular}

Note: Isomers of xylene are compared to the MCL of 10,000 micrograms per liter for total xylenes, and disinfection by-products are compared to the MCL of 80 micrograms per liter for the sum of the four trihalomethanes

Figure 17. During the second phase of sampling, June 2004-August 2005, $A$, annual mean concentrations of commonly detected anthropogenic organic compounds in finished-water samples were less than humanhealth benchmarks; and $B$, maximum concentrations in single samples from each site generally were lower than human-health benchmarks. 
tion by-products was less than the MCL of $80 \mu \mathrm{g} / \mathrm{L}$ for total trihalomethanes in all finished-water samples. Atrazine was the only other compound for which annual mean concentrations were within a factor of 10 of the MCL. The annual mean BQ values were between 0.1 and 0.3 at the CWSs on the Elm Fork Trinity and White Rivers (fig. 17A), and the annual mean concentrations of atrazine were 0.46 and $0.72 \mu \mathrm{g} / \mathrm{L}$, respectively.

Even when single-sample maximum concentrations are considered, few compounds were detected in finished water at concentrations within a factor of 10 of their human-health benchmarks (fig. 17B). Of the commonly detected compounds, disinfection by-products and herbicides were the only primary use groups with BQmax values greater than 0.1. One detection of atrazine at $3.4 \mu \mathrm{g} / \mathrm{L}$ in a finished-water sample from the CWS on the White River was greater than its MCL $(3 \mu \mathrm{g} / \mathrm{L})$. As observed in source-water samples, some herbicides are present in surface water at relatively high concentrations seasonally following their use; however, concentrations often decrease subsequently. As a result, annual mean concentrations generally were about an order of magnitude less than the maximum detected concentration.

Concentrations of compounds detected in fewer than 10 percent of samples were almost always lower than their human-health benchmarks (Appendix 2). Only one infrequently detected compound in finished water was measured in a single sample at a concentration greater than a human-health benchmark. Benzo[a]pyrene has an MCL of $0.2 \mu \mathrm{g} / \mathrm{L}$ and was detected in only one finished-water sample at a concentration of $0.26 \mu \mathrm{g} / \mathrm{L}$. Benzo[a]pyrene was not detected in any other source- or finished-water samples during either phase of sampling.

\section{Mixtures of Compounds}

One objective of the comparisons of source and finished water was to evaluate potential differences in the frequency and complexity of mixtures of organic compounds. Both source- and finished-water samples usually contained mixtures of two or more compounds, and about one-half of samples of both source and finished water contained 14 or more compounds. Because disinfection by-products were formed during water treatment, finished water had a higher percentage of samples with mixtures than did source water when fewer than 15 compounds were detected (fig. 18). A smaller percentage of finished-water samples, however, contained more than 15 compounds compared to source water. Sourcewater samples containing mixtures with large numbers of compounds generally were from watersheds that had more agricultural and urban land use (fig. 8), and samples from these sites included larger numbers of compounds in source water rather than in finished water. Changes in concentration (transformation) of some compounds as a result of water treatment (for example, fipronil and its degradates) may account, in part, for the higher percentage of source-water samples having mixtures with more compounds than finished water.
Consumer Confidence Reports and SourceWater Quality Assessments

Nince 1999, the U.S. Environmental Protection $\checkmark$ Agency (USEPA) has required water suppliers to provide annual drinking-water quality reports called Consumer Confidence Reports (CCRs) to their customers (http://www.epa.gov/safewater/ccr/ccrfact.html). CCRs are the centerpiece of the right-to-know provisions of the 1996 Amendments to the Safe Drinking Water Act. Each CCR provides consumers with fundamental information about their drinking water including (1) the source of the drinking water, (2) a brief summary of the susceptibility to contamination of the local drinking-water source, (3) the concentrations (or range of concentrations) of any contaminants found in local drinking water, as well as their USEPA Maximum Contaminant Levels (MCLs), which are legally enforceable drinking-water standards and are the highest allowed concentrations of contaminants in drinking water, and (4) telephone numbers for additional sources of information.

\begin{abstract}
nformation in CCRs is specific to a particular water
utility. Water utilities analyze finished-water samples primarily for regulated compounds using USEPA analytical methods for compliance monitoring. In contrast, Source Water-Quality Assessments (SWQAs) performed by the U.S. Geological Survey (USGS) are not conducted for compliance monitoring but are used to characterize the water quality of selected rivers and aquifers at the point of withdrawal of a CWS supply. As part of SWQAs, both source- and finished-water samples are analyzed using USGS analytical methods. Analytical methods used in SWQAs include many more compounds and typically have lower analytical reporting levels than those used in USEPA analytical methods; therefore, compound detection frequencies in SWQA reports may be higher than those reported in CCRs.
\end{abstract}

As discussed previously in relation to mixture occurrence in source water, the potential human-health significance of the frequent presence of mixtures of organic compounds remains largely unknown. The frequent occurrence of mixtures in both source- and finished-water samples points to a need for identifying which specific combinations of compounds occur most commonly and which may be a potential concern for human health. Identification of specific combinations of compounds would provide initial perspective on co-occurrence that may be important as more is learned about sources and potential health effects of mixtures. Again, these are important research topics, but are beyond the scope of this report. 


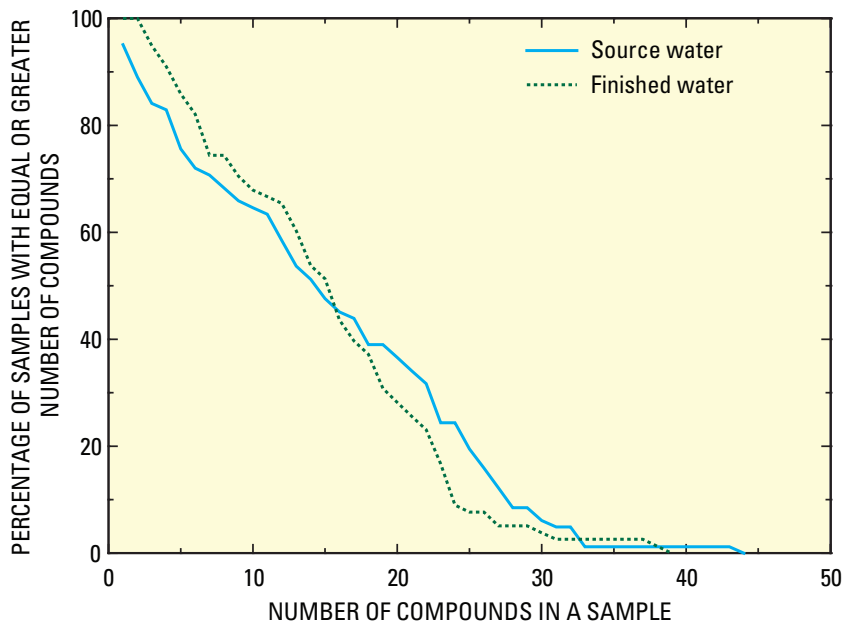

Figure 18. About one-half of source- and finished-water samples collected during the second phase of sampling, June 2004-August 2005 , contained mixtures of 14 or more compounds.

\section{Summary and Conclusions}

Source Water-Quality Assessments (SWQAs) by the U.S. Geological Survey's National Water-Quality Assessment (NAWQA) Program characterize the quality of source and finished water of selected community water systems (CWSs) that use streams or aquifers for drinking water. SWQA studies of CWSs that withdraw water from streams, the subject of this report, were conducted in two phases, with sample collection lasting about a year during each of the phases. During the first phase of sampling (October 2002-March 2004), nine streams that are used as a source of drinking water were sampled about monthly for analysis of 258 anthropogenic organic compounds over about a year's time to characterize the quality of these source waters. Eight of these sites were sampled for a second year during the second phase of sampling (June 2004-August 2005), and corresponding finished-water samples (after treatment and before distribution) were collected monthly to characterize the extent to which compounds detected in the source water were present in the finished water. Three additional herbicides and 16 degradates were analyzed in samples from a subset of sites during both sampling phases.

The contributing watersheds to these streams range in size from 1 to about 11,500 square miles, but seven were between about 480 and 2,500 square miles. Four of the watersheds can be characterized as undeveloped with relatively little urban land use (less than 5 percent) or agricultural land use (less than 25 percent); three watersheds have mixed land use; and two watersheds have greater than 50 percent agricultural land use. The CWSs withdrawing from these streams range in size from small to very large, serving from about 3,000 people to 2 million people. Water treatment at most of the CWSs is conventional, which typically includes the steps of coagulation, flocculation, sedimentation, filtration, and disinfection. One of the CWSs uses slow sand filtration, a second uses

\section{USEPA Drinking Water Levels of} Comparison for Atrazine and its Degradates in Community Water Systems

A s part of the reregistration of atrazine in 2003, the A U.S. Environmental Protection Agency developed drinking-water levels of comparison (DWLOCs) for the sum of atrazine and its three chlorinated degradates (deethylatrazine, deisopropylatrazine, and deethyldeisopropyl atrazine), referred to as total chlorotriazines (TCT), in source water for a community water system (CWS). DWLOCs are the maximum concentrations in drinking water that, when considered together with other dietary exposure, do not exceed a level of concern.

T he DWLOC for TCT is a 90-day moving average of 37.5 micrograms per liter $(\mu \mathrm{g} / \mathrm{L})$ if source-water samples are collected from CWSs at least weekly during the growing season (biweekly the remainder of the year); the DWLOC for TCT is a 90-day moving average of $12.5 \mu \mathrm{g} / \mathrm{L}$ if monitoring during the growing season is less frequent (U.S. Environmental Protection Agency, 2003). Concentrations greater than these DWLOCs indicate the need for further analysis and monitoring.

$\sim$ urrently (2008), the USEPA is transitioning away from the use of DWLOCs and developing a probabilistic approach to assessing exposure and risk from TCT in drinking water. This probabilistic approach will incorporate the same methodologies used in other cumulative risk assessments for organophosphate and N-methyl carbamate pesticides (Catherine Eiden, U.S. Environmental Protection Agency, oral commun., 2008).

A lthough the probabilistic approach will change this study are compared to the existing DWLOC values as a preliminary evaluation. Samples were collected less frequently than weekly during the growing season and less frequently than biweekly during the remainder of the year at all Source Water-Quality Assessment (SWQA) sites, so 90-day moving average concentrations of TCT were compared to the $12.5 \mu \mathrm{g} / \mathrm{L}$ benchmark for evaluations of all sites. None of the SWQA sites had a maximum 90-day average greater than $12.5 \mu \mathrm{g} / \mathrm{L}$. The maximum 90-day average concentration of TCT in source water was at the White River, Indiana, which had a maximum of $6.4 \mu \mathrm{g} / \mathrm{L}$ during the first phase and $2.1 \mu \mathrm{g} / \mathrm{L}$ during the second phase of the SWQA sampling.

ozone as a preliminary treatment step, and a third uses direct filtration. Four of the CWSs use powdered activated carbon intermittently for taste- and odor-issues or removal of organic compounds. 
Of the 258 organic compounds analyzed at all sites, 134 compounds were detected at least once in source-water samples collected during the first phase of sampling, but many of these compounds were detected infrequently and at low concentrations - less than 0.1 microgram per liter $(\mu \mathrm{g} / \mathrm{L})$. A total of 119 compounds were not detected in any sample. Annual mean concentrations of all compounds detected in source water were less than available human-health benchmarks. Maximum single-samples concentrations also were almost always less than benchmarks. Atrazine, one of the most heavily used herbicides in the Nation, was the only compound detected in source-water samples at a concentration $(20.5 \mu \mathrm{g} / \mathrm{L})$ greater than its Maximum Contaminant Level (MCL) of $3 \mu \mathrm{g} / \mathrm{L}$ for drinking water. The annual mean concentration for atrazine in source water at this site was $2.2 \mu \mathrm{g} / \mathrm{L}$. Instantaneous high concentrations in source water do not represent a violation of an MCL, which is based on an annual mean concentration in finished water. Elevated concentrations of atrazine and several other herbicides in source water generally were associated with their application during the spring in watersheds with agricultural land use. Acetochlor and dieldrin were each detected once in source water at concentrations greater than their respective Health-Based Screening Level concentration.

Chloroform was the most commonly detected compound, in about 70 percent of all samples and at eight of the nine sites. It was detected in every sample throughout the year at sites on the Elm Fork Trinity, Neuse, Potomac, and White Rivers and at Running Gutter Brook. The fragrance compounds acetyl hexamethyl tetrahydronaphthalene (AHTN) and hexahydrohexamethycyclopentabenzopyran (HHCB) also were commonly detected in about 50 percent of samples and at as many as eight of the stream sites. Findings for these compounds and chloroform indicate an association between their occurrence and upstream wastewater discharges. The largest number of detections of these compounds was found at five sites that included major municipal wastewater discharges (greater than 1 million gallons per day) upstream from the sampling location. Four sites without major wastewater discharges upstream had relatively few or no detections of these compounds with the exception of Running Gutter Brook where chloroform was detected in every sample. Detections of chloroform in every sample from Running Gutter Brook, which does not receive any major wastewater discharge, demonstrate that these compounds can have multiple sources, and an understanding of local hydrology and sources of contaminants is needed to fully characterize source-water quality.

Herbicides and their degradates were among the most commonly detected compounds in source water. The most commonly detected herbicides - simazine, atrazine and its degradates (deethylatrazine and deisopropylatrazine), metolachlor, prometon, and 2,4-D - were detected in about 50 percent or more of samples at six of the nine sites. Degradates of these herbicides, as well as diruon, generally were detected at concentrations similar or greater than concentrations of the parent compounds. Some herbicides, for example acetochlor and alachlor, were detected commonly in one or two watersheds, likely a result of corn cultivation in these watersheds. The herbicides detected in these source waters in this study also were among the most commonly detected herbicides in streams across the Nation sampled by the NAWQA Program between 1992 and 2001.

Three insecticides - diazinon, fipronil, and carbarylwere detected most commonly in samples from five watersheds with overall detection frequencies of 39, 29, and 15 percent, respectively. Both diazinon and carbaryl were among the most commonly detected insecticides in streams sampled by the NAWQA Program between 1992 and 2001, and detection frequencies were highest in watersheds characterized as urban. No insecticides were detected in any samples from sites in this study with less than 1 percent urban land use in their watersheds. Notably, the detection frequency of diazinon in source water decreased between samples collected during 2002-04 and samples collected during 2004-05, probably because of the phase out of its use in December 2004.

During the first phase of sampling, source-water samples typically contained mixtures of two or more compounds: about three-quarters of source-water samples contained 5 compounds, and about one-half contained at least 13 compounds. The most commonly detected compounds in mixtures were those individual compounds detected most commonly, such as chloroform and herbicides and their degradates. The number of compounds and the total concentration of compounds detected in a sample generally increased as the amount of urban and agricultural land use in the watershed increased. Samples from sites in undeveloped watersheds (Cache la Poudre, Clackamas, and Truckee Rivers and Running Gutter Brook) typically contained 10 or fewer compounds, with total concentrations of detected compounds generally less than $0.5 \mu \mathrm{g} / \mathrm{L}$. The median number of compounds in samples from sites with predominantly agricultural or mixed land use (Chattahoochee, Elm Fork Trinity, Neuse, Potomac, and White Rivers) was between 9 and 30, with total median concentrations of detected compounds between 1 and $4 \mu \mathrm{g} / \mathrm{L}$.

The comparison between source- and finished-water quality in this report is not intended as an evaluation of watertreatment efficacy at these CWSs. Rather, the results from this study represent a characterization of how source- and finishedwater quality vary over the course of about a year at eight CWSs that use treatment steps typical of many CWSs across the county. Finished-water samples were collected at the treatment plant following all of the treatment steps and before distribution and therefore are not necessarily representative of drinking-water quality at the tap (or point of delivery). Additional contact time with disinfectants in the distribution system may change concentrations of some of the compounds detected in the finished water at the sample-collection point. It is important to note that conventional water treatment in general, and most of the treatment steps used by the CWSs 
sampled, are not specifically designed to remove many of the anthropogenic organic compounds monitored in this study.

About two-thirds of the most commonly detected compounds in source water had similar detection frequencies in finished water. Concentrations of these compounds commonly were lower in finished water than in the corresponding source-water sample, but the amount of change for many of these compounds was not large, and typically was less than 25 percent. Compounds that were detected at similar detection frequencies in both source and finished water include the commonly detected herbicides such as atrazine, its degradates, and simazine, as well as personalcare and domestic-use compounds such as the fragrances HHCB and AHTN. About one-quarter of the most commonly detected compounds in source and finished water had detection frequencies in finished water that were about one-half or less than the detection frequency in source water. A few compounds, including the organophosphate insecticides, fipronil, 3,4-dichloroaniline (diuron degradate), and aromatic hydrocarbons with one or more methyl groups, typically were not present at detectable concentrations in finished water although they were detected in source water. The decrease in concentration of these compounds likely was the result of degradation or transformation as a result of disinfection.

Annual mean concentrations in finished water were less than human-health benchmarks. Maximum single-sample concentrations also were less than human-health benchmarks with two exceptions. Atrazine was detected at a concentration of $3.4 \mu \mathrm{g} / \mathrm{L}$ in a finished-water sample from the White River CWS. The annual mean concentration of atrazine in finishedwater samples at the CWS on the White River was $0.72 \mu \mathrm{g} / \mathrm{L}$, which is considerably less than the MCL of $3 \mu \mathrm{g} / \mathrm{L}$. Benzo[a]pyrene was detected one time in finished water at a concentration of $0.26 \mu \mathrm{g} / \mathrm{L}$, which is slightly greater than its $\mathrm{MCL}$ of $0.2 \mu \mathrm{g} / \mathrm{L}$. Benzo[a]pyrene was not detected in any sourcewater samples. All other maximum concentrations in finished water were less than applicable human-health benchmarks.

Although water-treatment steps used by these eight CWSs differ somewhat, large differences (greater than 75 percent) in the amount of change in concentration between source water and finished water generally were not observed for those compounds with similar detection frequencies in source and finished water. The comparison of changes in concentration is limited because of other factors that may have affected findings, such as sampling timing and analytical error for compounds present at concentrations near the reporting level.

Changes in source-water quality during the year usually are reflected in finished-water quality. For compounds that were present in both source- and finished-water samples, varying concentrations in source water typically resulted in corresponding concentrations in finished water, although concentrations commonly were lower in finished water than in source water. At some CWSs, the amount of change between source and finished water varied. These differences in the amount of change in concentration from source to finished water may reflect changes in water treatment at the CWSs, including the occasional use of powdered activated carbon to remove taste- and odor-compounds or other organic compounds.

Source- and finished-water samples typically contained mixtures of two or more compounds, and about 50 percent of both sample types contained 14 or more compounds. The frequent occurrence of a number of compounds typically at concentrations less than applicable human-health benchmarks in source water and the associated finished water has several implications, one of which is the importance of source-water characterization. For these eight CWSs, which use treatment steps typical of many water systems across the Nation that withdraw water from streams, concentrations of many of the most commonly occurring compounds in source water did not change appreciably following treatment. Understanding gained from resource assessments about how organic compounds move through the hydrologic system, and factors that affect their occurrence, may provide water-resource managers with information that can be used to minimize the effect of these contaminants on drinking-water quality.

Results from these studies also indicate that although concentrations of compounds detected typically were considerably less than human-health benchmarks, the frequent occurrence of mixtures in finished waters points to a need for indentifying mixtures that are most common and most likely to have potential human-health effects. Also, the importance of degradates in addressing the potential risk of exposure to the parent compounds has begun to be incorporated into humanhealth benchmarks, for example atrazine and its degradates. Yet more information is needed to understand the formation, fate, and transport of degradates in the environment as well as the formation of degradates and transformation products during water treatment.

\section{References}

Adams, C.D., and Randtke, S.J., 1992, Ozonation byproducts of atrazine in synthetic and natural waters: Environmental Science and Technology, v. 26, no. 11, p. 2,218-2,227.

Aizawa, T., Magara, Y., Takagi, H., and Souna, F., 1994, Chlorination by-products of pesticides in drinking water: Water Supply, v. 12, p. SS11-6 through SS11-9.

Bester, Kai, 2004, Retention characteristics and balance assessment for two polynuclear musk fragrances (HHCB and AHTN) in a typical German sewage treatment plant: Chemosphere, v. 57, p. 863-870.

Carpenter, D.O., Arcaro, K., and Spink, D.C, 2002, Understanding the human health effects of chemical mixtures: Environmental Health Perspectives, v. 110, p. 25-42. 
Carter, J.M., Delzer, G.C., Kingsbury, J.A., and Hopple, J.A., 2007, Concentration data for anthropogenic organic compounds in ground water, surface water, and finished water of selected community water systems in the United States, 2002-05: U.S. Geological Survey Data Series 268, accessed June 6, 2008, at http://pubs.usgs.gov/ds/2007/268/.

Christman, R.F., 1980, Chemistry of the use of chlorine in water and food processing in Jolley, R.L., Brungs, W.A., and Cumming, R.B., eds., Water chlorination, environmental impact and health effects: Ann Arbor, Mich., Ann Arbor Science Publishers, Inc., v. 3, 1,171 p.

Connor, B.F., Rose, D.L., Noriega, M.C., Murtagh, L.K., and Abney, S.R., 1998, Methods of analysis by the U.S. Geological Survey National Water Quality Laboratory-Determination of 86 volatile organic compounds in water by gas chromatography/mass spectrometry, including detections less than reporting limits: U.S. Geological Survey OpenFile Report 97-829, 78 p.

Coupe, R.H., and Blomquist, J.D., 2004, Water-soluble pesticides in finished water of community water supplies: Journal of the American Water Resources Association, v. 96, no. 10, p. $56-68$.

Delzer, G.C., and Hamilton, P.A., 2007, National WaterQuality Assessment Program-Source Water-Quality Assessments: U.S. Geological Survey Fact Sheet 20073069, 2 p., accessed October 1, 2007, at http://pubs.usgs. gov/fs/2007/3069/.

Duguet, J.P., Bernazeau, F., and Bruchet, A., 1994, Occurrence of pesticides in natural waters and removal during drinking water treatment processes: Water Supply, v. 12, p. SS11-1 through SS11-5.

Frick, E.A., Hippe, D.J., Buell, G.R., Couch, C.A., Hopkins, E.H., Wangsness, D.J., and Garrett, J.W., 1998, Water quality in the Apalachicola-Chattahoochee-Flint River Basin, Georgia, Alabama, and Florida, 1992-95: U.S. Geological Survey Circular 1164, 38 p.

Furlong, E.T., Anderson, B.D., Werner, S.L., Soliven, P.P., Coffey, L.J., and Burkhardt, M.R., 2001, Methods of analysis by the U.S. Geological Survey National Water Quality Laboratory-Determination of pesticides in water by graphitized carbon-based solid-phase extraction and high-performance liquid chromatography/mass spectrometry: U.S. Geological Survey Water-Resources Investigations Report 01-4134, 73 p.

Gilliom, R.J., Alexander, R.B., and Smith, R.A., 1985, Pesticides in the Nation's rivers, 1975-1980, and implications for future monitoring: U.S. Geological Survey Water-Supply Paper 2271, 26 p.
Gilliom, R.J., Barbash, J.E., Crawford, C.G., Hamilton, P.A., Martin, J.D., Nakagaki, N., Nowell, L.H., Scott, J.C., Stackelberg, P.E., Thelin, G.P., and Wolock, D.M., 2006, The quality of our Nation's waters-Pesticides in the Nation's streams and ground water, 1992-2001: U.S. Geological Survey Circular 1291, 172 p.

Grady, S.J., 2003, A national survey of methyl tert-butyl ether and other volatile organic compounds in drinking-water sources-Results of the random survey: U.S. Geological Survey Water-Resources Investigations Report 02-4079, $85 \mathrm{p}$.

Halling-Sorensen, B., Nielson, S.N., Lanzky, P.F., Ingerslev, F., Holten Lutzhoft, H.C., and Jorgensen, S.E., 1998, Occurrence, fate and effects of pharmaceutical substances in the environment-A review: Chemosphere 1998, v. 36, p. 357-393.

Helsel, D.R., and Hirsch, R.M., 1992, Statistical methods in water resources: New York, Elsevier, 522 p.

Ivahnenko, Tamara, and Barbash, J.E., 2004, Chloroform in the hydrologic system - Sources, transport, fate, occurrence, and effects on human health and aquatic organisms: U.S. Geological Survey Scientific Investigations Report 2004-5137, $34 \mathrm{p}$.

Ivahnenko, Tamara, and Zogorski, J.S., 2006, Sources and occurrence of chloroform and other trihalomethanes in drinking-water supply wells in the United States, 19862001: U.S. Geological Survey Scientific Investigations Report 2006-5015, 13 p.

Jiang, H., and Adams, C., 2006, Treatability of chloro-striazines by conventional drinking water treatment technologies: Water Research, v. 40, no. 8, p. 1,657-1,667.

Kalkhoff, S.J., Kolpin, D.W., Thurman, E.M., Ferrer, I., and Barcelo, D., 1998, Degradation of chloroacetanilide herbicides-The prevalence of sulfonic and oxanilic acid metabolites in Iowa groundwaters and surface waters: Environmental Science and Technology, v. 32. no. 11, p. $1,738-1,740$.

Kolpin, D.W., Furlong, E.T., Meyer, M.T., Thurman, E.M., Zaugg, S.D., Barber, L.B., and Buxton, H.T., 2002, Pharmaceuticals, hormones, and other organic wastewater contaminants in U.S. streams, 1999-2000-A national reconnaissance: Environmental Science and Technology, v. 36, no. 6, p. $1,202-1,211$.

Kolpin, D.W., Skopec, M., Meyer, M.T., Furlong, E.T., and Zaugg, S.D., 2004, Urban contribution of pharmaceuticals and other organic wastewater contaminants to streams during differing flow conditions: Science of the Total Environment, v. 328, no. 1-3, p. 119-130. 
Krasner, S.W., Weinberg, H.S., Richardson, S.D., Pastor, S.J., Chinn, R., Sclimenti, M.J., Onstad, G.D., and Thurston, A.D., Jr., 2006, Occurrence of a new generation of disinfection byproducts: Environmental Science and Technology, v. 40 , no. 23 , p. $7,175-7,185$.

Laturnus, Frank, Haselmann, K.F., Borch, Thomas, and Gron, Christian, 2002, Terrestrial natural sources of trichloromethane (chloroform, $\mathrm{CHCl} 3$ ) - An overview: Biochemistry, v. 60, p. 121-139.

Lee, E.A., and Strahan, A.P., 2003, Methods of analysis by the U.S. Geological Survey Organic Geochemistry Research Group-Determination of acetamide herbicides and their degradation products in water using online solid-phase extraction and high-performance liquid chromatography/ mass spectrometry: U.S. Geological Survey Open-File Report 03-173, $17 \mathrm{p}$.

Lindley, C.E., Stewart, J.T., and Sandstrom, M.W., 1996, Determination of low concentrations of acetochlor in water by automated solid-phase extraction and gas chromatography with mass selective detection: Journal of Association of Official Analytical Chemists International, v. 79, no. 4, p. $962-966$.

Madsen, J.E., Sandstrom, M.W., and Zaugg, S.D., 2003, Methods of analysis by the U.S. Geological Survey National Water Quality Laboratory-A method supplement for the determination of fipronil and degradates in water by gas chromatography/mass spectrometry: U.S. Geological Survey Open-File Report 02-462, 11 p.

Magara, Y., Aizawa, T., Matumoto, N., and Souna, F., 1994, Degradation of pesticides by chlorination during water purification: Water Science and Technology, v. 30, no. 7, p. 119-128.

Miltner, R.J., Baker, D.B., Speth, T.F., and Fronk, C.A., 1989, Treatment of seasonal pesticides in surface waters: Journal of American Water Works Association, v. 81, no. 1, p. $43-52$.

Phillips, P.J., Stinson, B., Zaugg, S.D., Furlong, E.T., Kolpin, D.W., Esposito, K.M., Bodniewicz, B., Pape, R., and Anderson, J., 2005, A multi-disciplinary approach to the removal of emerging contaminants in municipal wastewater treatment plants in New York State, 2003-2004: Water Environment Federation WEFTEC 78th Annual Technical Exhibition and Conference, Proceedings, Washington, D.C., November 2005, p. 5,095-5,124.

Richards, J.J., Junk, G.A., Avery, M.J., Nehring, N.L., Fritz, J.S., and Svec, H.J., 1975, Analysis of Iowa waters for selected pesticides-Atrazine, DDE, and dieldrin, 1974: Pesticides Monitoring Journal, v. 9, p. 117-123.

Rook, 1974, Formation of haloforms during chlorination of natural water: Water Treatment Examiner, v. 23, p. 234-243.
Rose, D.L., and Sandstrom, M.W., 2003, Methods of analysis by the U.S. Geological Survey National Water Quality Laboratory-Determination of gasoline oxygenates, selected degradates, and BTEX in water by heated purge and trap/ gas chromatography/mass spectrometry: U.S. Geological Survey Water-Resources Investigations Report 03-4079, $31 \mathrm{p}$.

Sandstrom, M.W., Stroppel, M.E., Foreman, W.T., and Schroeder, M.P., 2001, Methods of analysis by the U.S. Geological Survey National Water Quality LaboratoryDetermination of moderate-use pesticides and selected degradates in water by $\mathrm{C}-18$ solid-phase extraction and gas chromatography/mass spectrometry: U.S. Geological Survey Water-Resources Investigations Report 01-4098, 70 p.

Shelton, L.R., 1994, Field guide for collecting and processing stream-water samples for the National Water-Quality Assessment Program: U.S. Geological Survey Open-File Report 94-455, $42 \mathrm{p}$.

Shelton, L.R., 1997, Field guide for collecting samples for analysis of volatile organic compounds in stream water for the National Water-Quality Assessment Program: U.S. Geological Survey Open-File Report 97-401, 14 p.

Snyder, S.A., Westerhoff, P., Yoon, Y., and Sedlak, D.L., 2003, Pharmaceuticals, personal care products, and endocrine disruptors in water-Implications for the water industry: Environmental Engineering Science, v. 20, no. 5, p. 449-469.

Stackelberg, P.E., Furlong, E.T., Meyer, M.T., Zaugg, S.D., Henderson, A.K., and Reissman, D.B., 2004, Persistence of pharmaceutical compounds and other organic wastewater contaminants in a conventional drinking-water-treatment plant: Science of the Total Environment, v. 329, no. 1-3, p. $99-113$.

Ternes, T.A., Meisenheimer, M., McDowell, D., Sacher, F., Branch, H.J., Hsiate-Guide, B., Preuss, G., Wilme, U., and Zulei-Seibert, N., 2002, Removal of pharmaceuticals during drinking water treatment: Environmental Science and Technology, v. 36 , p. $3,855-3,863$.

Thurman, E.M., Goolsby, D.A., Meyer, M.T., Mills, M.S., Pomes, M.L., and Kolpin, D.W., 1992, A reconnaissance study of herbicides and their metabolites in surface water of the Midwestern United States using immunoassay and gas chromatography/mass-spectrometry: Environmental Science and Technology, v. 26, no. 12 , p. 2,440-2,447.

Toccalino, P.L., 2007, Development and application of Health-Based Screening Levels for use in water-quality assessments: U.S. Geological Survey Scientific Investigations Report 2007-5106, 12 p., http://pubs.usgs.gov/ sir/2007/5106/. 
Toccalino, Patricia; Nowell, Lisa; Wilber, William; Zogorski, John; Donohue, Joyce; Eiden, Catherine; Krietzman, Sandra; and Post, Gloria, 2003, Development of HealthBased Screening Levels for use in State- or local-scale water-quality assessments: U.S. Geological Survey WaterResources Investigations Report 03-4054, 22 p.

Toccalino, P.L., Norman, J.E., Booth, N.L, and Zogorski, J.S., 2006, Health-Based Screening Levels-A tool for evaluating what water-quality data may mean to human health: U.S. Geological Survey, National Water-Quality Assessment Program, accessed July 20, 2007, at http://water.usgs.gov/ nawqa/HBSL/.

Toccalino, P.L., Rowe, B.L., and Norman, J.E., 2006, Volatile organic compounds in the Nation's drinking-water supply wells - What findings may mean to human health: U.S. Geological Survey Fact Sheet 2006-3043, 4 p., http://pubs. usgs.gov/fs/2006/3043/.

U.S. Department of Agriculture, 2008, Agricultural Research Service (ARS), Pesticide Data Program: accessed March 6, 2008, at http://www.ams.usda.gov/science/pdp/.

U.S. Environmental Protection Agency, 1998a, Code of Federal Regulations, title 40-Protection of environment, chapter 1-Environmental Protection Agency, subchapter E-Pesticide programs, part 159 — Statements of policies and interpretations, subpart D-Reporting requirements for risk/benefit information, 40 CFR 159.184: National Archives and Records Administration, September 19, 1997; amended June 19, 1998, accessed October 15, 2008, at http://www.gpoaccess.gov/ecfr/index.html

U.S. Environmental Protection Agency, 1998b, Code of Federal Regulations, title 40-Protection of environment, chapter 1-Environmental Protection Agency, subchapter D-Water programs, part 141-National primary drinking water regulations, 40 CFR 141.24: National Archives and Records Administration, September 19, 1997; amended June 19, 1998, accessed November 4, 2008, at http://www. gpoaccess.gov/ecfr/index.html

U.S. Environmental Protection Agency, 2003, Interim reregistration eligibility decision for atrazine - Case No. 0062: U.S. Environmental Protection Agency, accessed January17, 2008, at http://www.epa.gov/pesticides/reregistration/REDs/ atrazine_ired.pdf

U.S. Environmental Protection Agency, 2005, Fact sheet-The Drinking Water Contaminant Candidate List-The source of priority pollutants for the Drinking Water Program: U.S. Environmental Protection Agency EPA 815-F-05-001, accessed January 2, 2008, at www.epa.gov/safewater/ccl/ $p d f s / f_{s}$ ccl2_final-02-23-05.pdf

U.S. Environmental Protection Agency, 2006a, Public drinking water systems program, accessed August, 30, 2006, at http://www.epa.gov/safewater/pws/factoids.html
U.S. Environmental Protection Agency, 2006b, Envirofacts Data Warehouse, Permit Compliance System: accessed October 2, 2006, at http://www.epa.gov/enviro/html/pcs/ pcs_query.html

U.S. Environmental Protection Agency, 2006c, 2006 Edition of the drinking water standards and health advisories: Washington, D.C., U.S. Environmental Protection Agency, Office of Water EPA 822-R-06-013, August 2006, 18 p., http:// www.epa.gov/waterscience/criteria/drinking/dwstandards. $p d f$

U.S. Environmental Protection Agency, 2007, UCMR: accessed April 9, 2008, at http://www.epa.gov/safewater/ ucmr/index.html

U.S. Environmental Protection Agency, 2008a, Setting standards for safe drinking water: Washington, D.C., U.S. Environmental Protection Agency, Office of Ground Water and Drinking Water, accessed February 13, 2008, at http:// www.epa.gov/safewater/standard/setting.html

U.S. Environmental Protection Agency, 2008b: DiazinonPhase out of all residential uses of the insecticide: accessed on March 14, 2008, at http://www.epa.gov/pesticides/ factsheets/chemicals/diazinon-factsheet.htm

U.S. Geological Survey, 2007, Facing tomorrow's challenges-U.S. Geological Survey science in the decade 2007-2017: U.S. Geological Survey Circular 1309, 70 p.

Valder, J.F., Delzer, G.C., Price, C.V., and Sandstrom, M.W., 2008, Study design and percent recoveries of anthropogenic organic compounds with and without the addition of ascorbic acid to preserve samples containing free chlorine, 2004-06: U.S. Geological Survey Open-File Report 2008-1226, 85 p., accessed August 26, 2008, at http://pubs. usgs.gov/of/2008/1226/.

Verstraeten, I.M., Thurman, E.M., Lindsey, M.E., Lee, E.C., and Smith, R.D., 2002, Changes in concentrations of triazine and acetamide herbicides by bank filtration, ozonation, and chlorination in a public water supply: Journal of Hydrology, v. 266, p. 190-208.

Vogelmann, J.E., Howard, S.M., Yang, L., Larson, C.R., Wylie, B.K., and VanDriel, Nick, 2001, Completion of the 1990's national land cover dataset for the conterminous United States from Landsat Thematic Mapper data and ancillary data sources: Photogrammetric Engineering and Remote Sensing, v. 67, p. 650-662.

Westerhoff, Paul; Yoon, Yeomin; Snyder, Shane; and Wert, Eric, 2005, Fate of endocrine-disruptor, pharmaceutical, and personal care product chemicals during simulated drinking water treatment processes: Environmental Science and Technology, v. 39, no. 17, p. 6,649-6,663. 
Westrick, J.J., 1990, National surveys of volatile organic compounds in ground and surface waters, in Ram, N.M., Christman, R.F., and Cantor, K.P., eds., Significance and treatment of volatile organic compounds in water supplies: Chelsea, Mich., Lewis Publishers, p. 103-125.

Winslow, S.D., Prakash, Brahm, Domino, M.M., and Pepich, B.V., 2001, Considerations necessary in gathering occurrence data for selected unstable compounds in the USEPA unregulated contaminant candidate list in USEPA method 526: Environmental Science and Technology, v. 35, no. 9 , p. $1,851-1,858$.

Zaugg, S.D., Sandstrom, M.W., Smith, S.G., and Fehlberg, K.M., 1995, Methods of analysis by the U.S. Geological Survey National Water Quality Laboratory-Determination of pesticides in water by $\mathrm{C}-18$ solid-phase extraction and capillary-column gas chromatography/mass spectrometry with selected-ion monitoring: U.S. Geological Survey Open-File Report 95-181, 60 p.

Zaugg, S.D., Smith, S.G., Schroeder, M.P., Barber, L.B., and Burkhardt, M.R., 2002, Methods of analysis by the U.S. Geological Survey National Water Quality LaboratoryDetermination of wastewater compounds by polystyrenedivinylbenzene solid-phase extraction and capillary-column gas chromatography/mass spectrometry: U.S. Geological Survey Water-Resources Investigations Report 01-4186, $37 \mathrm{p}$. 


\section{Appendixes}


Appendix 1. Summary statistics and human-health benchmarks for anthropogenic organic compounds analyzed in source-water samples collected during the first phase of sampling, October 2002-March 2004.

[Compounds within each primary-use category are listed in order from highest to lowest detection frequency; CASRN, Chemical Abstracts Service Registry Number; E, estimated; AHTN, acetyl hexamethyl tetrahydronaphthalene; HHCB, hexahydrohexamethylcyclopentabenzopyran; MCPA, 2-methyl-4-chlorophenoxyacetic acid; MCL, Maximum Contaminant Level; HBSL, Health-Based Screening Level; ND, not detected; $\mu \mathrm{g} / \mathrm{L}$, micrograms per liter; --, no data; $\mathrm{R}$, removed from data set; $\mathrm{C}$, censored]

\begin{tabular}{|c|c|c|c|c|c|c|c|c|}
\hline $\begin{array}{c}\text { Compound } \\
\text { (other name or abbreviation) }\end{array}$ & CASRN ${ }^{1}$ & $\begin{array}{c}\text { Number } \\
\text { of } \\
\text { samples }\end{array}$ & $\begin{array}{c}\text { Detection } \\
\text { frequency } \\
\text { (percent) }\end{array}$ & $\begin{array}{c}\text { Laboratory } \\
\text { reporting level } \\
(\mu \mathrm{g} / \mathrm{L})\end{array}$ & $\begin{array}{c}\text { Maximum } \\
\text { detected } \\
\text { concentration } \\
(\mu \mathrm{g} / \mathrm{L})\end{array}$ & $\begin{array}{c}\text { Detection } \\
\text { frequency at } \\
0.1 \mu \mathrm{g} / \mathrm{L} \text { assess- } \\
\text { ment level }\end{array}$ & $\begin{array}{c}\text { Type of } \\
\text { human-health } \\
\text { benchmark }^{2}\end{array}$ & $\begin{array}{l}\text { Human-health } \\
\text { benchmark } \\
(\mu \mathrm{g} / \mathrm{L})\end{array}$ \\
\hline \multicolumn{9}{|c|}{ Disinfection by-products } \\
\hline Chloroform $^{3}$ & $67-66-3$ & 147 & 69.4 & 0.024 & 2.86 & 15.6 & MCL & 80 \\
\hline Bromodichloromethane $^{3}$ & $75-27-4$ & 147 & 20.4 & .028 & .51 & 3.4 & MCL & 80 \\
\hline Dibromochloromethane ${ }^{3}$ & $124-48-1$ & 147 & 4.1 & .1 & .17 & .7 & MCL & 80 \\
\hline Bromoform $^{3}$ & $75-25-2$ & 147 & .7 & .1 & $.098 \mathrm{E}$ & ND & MCL & 80 \\
\hline \multicolumn{9}{|c|}{ Fumigant-related compounds } \\
\hline 1,4-Dichlorobenzene ${ }^{4}$ & $106-46-7$ & 147 & 9.5 & 0.034 & $0.083 \mathrm{E}$ & ND & MCL & 75 \\
\hline 1,2-Dichloropropane & $78-87-5$ & 147 & 1.4 & .029 & $.016 \mathrm{E}$ & ND & MCL & 5 \\
\hline 1,2-Dibromoethane & $106-93-4$ & 147 & ND & .036 & ND & ND & MCL & .05 \\
\hline 1,2-Dibromo-3-chloropropane & $96-12-8$ & 147 & ND & .51 & ND & ND & MCL & .2 \\
\hline 1,3-Dichloropropane 5 & $142-28-9$ & 147 & ND & .06 & ND & $\mathrm{ND}$ & -- & -- \\
\hline 2,2-Dichloropropane ${ }^{5}$ & $594-20-7$ & 147 & ND & .05 & ND & ND & -- & -- \\
\hline Bromomethane $^{5}$ & $74-83-9$ & 147 & ND & .33 & ND & ND & HBSL & 100 \\
\hline cis-1,3-Dichloropropene $e^{5,6}$ & $10061-01-5$ & 147 & ND & .05 & ND & ND & HBSL & ${ }^{2} .3$ \\
\hline trans-1,3-Dichloropropene $\mathrm{e}^{5,6}$ & $10061-02-6$ & 147 & ND & .09 & ND & ND & HBSL & ${ }^{2} .3$ \\
\hline \multicolumn{9}{|c|}{ Fungicides } \\
\hline Benomyl & $17804-35-2$ & 145 & 12.4 & 0.022 & $0.12 \mathrm{E}$ & 0.7 & HBSL & 40 \\
\hline Metalaxyl & $57837-19-1$ & 145 & 4.8 & .007 & .015 & ND & HBSL & 600 \\
\hline Pentachlorophenol & $87-86-5$ & 145 & 3.4 & 2 & $.32 \mathrm{E}$ & 2.1 & MCL & 1 \\
\hline Myclobutanil & $88671-89-0$ & 146 & 2.7 & .033 & .021 & ND & HBSL & 200 \\
\hline Propiconazole & -- & 145 & .7 & .01 & .042 & ND & HBSL & 70 \\
\hline Chlorothalonil & $1897-45-6$ & 145 & ND & .035 & ND & ND & HBSL & 5 \\
\hline Iprodione & $36734-19-7$ & 145 & ND & .026 & ND & ND & HBSL & .8 \\
\hline \multicolumn{9}{|c|}{ Gasoline hydrocarbons, oxygenates, and oxygenate degradates } \\
\hline $\begin{array}{l}\text { Methyl tert-butyl ether } \\
\quad(\mathrm{MTBE})^{4}\end{array}$ & $1634-04-4$ & 147 & 36.1 & 0.1 & 3.44 & 18.4 & - & -- \\
\hline Benzene & $71-43-2$ & 130 & 30.8 & .021 & .46 & 4.6 & MCL & 5 \\
\hline
\end{tabular}


Appendix 1. Summary statistics and human-health benchmarks for anthropogenic organic compounds analyzed in source-water samples collected during the first phase of sampling, October 2002-March 2004. - Continued

[Compounds within each primary-use category are listed in order from highest to lowest detection frequency; CASRN, Chemical Abstracts Service Registry Number; E, estimated; AHTN, acetyl hexamethyl tetrahydronaphthalene; HHCB, hexahydrohexamethylcyclopentabenzopyran; MCPA, 2-methyl-4-chlorophenoxyacetic acid; MCL, Maximum Contaminant Level; HBSL, Health-Based Screening Level; ND, not detected; $\mu \mathrm{g} / \mathrm{L}$, micrograms per liter; --, no data; R, removed from data set; $\mathrm{C}$, censored]

\begin{tabular}{|c|c|c|c|c|c|c|c|c|}
\hline $\begin{array}{c}\text { Compound } \\
\text { (other name or abbreviation) }\end{array}$ & CASRN' & $\begin{array}{l}\text { Number } \\
\text { of } \\
\text { samples }\end{array}$ & $\begin{array}{c}\text { Detection } \\
\text { frequency } \\
\text { (percent) }\end{array}$ & $\begin{array}{c}\text { Laboratory } \\
\text { reporting level } \\
(\mu \mathrm{g} / \mathrm{L})\end{array}$ & $\begin{array}{c}\text { Maximum } \\
\text { detected } \\
\text { concentration } \\
(\mu \mathrm{g} / \mathrm{L})\end{array}$ & $\begin{array}{c}\text { Detection } \\
\text { frequency at } \\
0.1 \mu \mathrm{g} / \mathrm{L} \text { assess- } \\
\text { ment level }\end{array}$ & $\begin{array}{c}\text { Type of } \\
\text { human-health } \\
\text { benchmark }^{2}\end{array}$ & $\begin{array}{l}\text { Human-health } \\
\text { benchmark } \\
(\mu \mathrm{g} / \mathrm{L})\end{array}$ \\
\hline \multicolumn{9}{|c|}{ Gasoline hydrocarbons, oxygenates, and oxygenate degradates-Continued } \\
\hline Toluene & $108-88-3$ & 130 & 17.7 & 0.02 & 1.98 & 9.2 & MCL & 1,000 \\
\hline$m$ - and $p$-Xylene & $\begin{array}{l}106-42-3 \\
108-38-3\end{array}$ & 147 & 12.9 & .06 & 1.40 & 6.8 & MCL & ${ }^{7} 10,000$ \\
\hline $1,2,4$-Trimethylbenzene ${ }^{5}$ & $95-63-6$ & 147 & 11.6 & .0556 & .52 & 3.4 & -- & -- \\
\hline tert-Butyl alcohol & $75-65-0$ & 145 & 11.0 & 1 & 1.05 & 11.0 & -- & -- \\
\hline$o$-Xylene & $95-47-6$ & 147 & 10.9 & .038 & .55 & 4.8 & MCL & ${ }^{7} 10,000$ \\
\hline Ethylbenzene & $100-41-4$ & 147 & 8.8 & .03 & .36 & .7 & MCL & 700 \\
\hline $\begin{array}{l}\text { 1-Ethyl-2-methylbenzene } \\
\text { (o-Ethyl toluene) }\end{array}$ & $611-14-3$ & 147 & 6.8 & .038 & .12 & .7 & -- & -- \\
\hline 1,3,5-Trimethylbenzene & $108-67-8$ & 147 & 5.4 & .044 & .15 & .7 & -- & -- \\
\hline 1,2,3-Trimethylbenzene & $526-73-8$ & 147 & 3.4 & .09 & $.11 \mathrm{E}$ & .7 & -- & -- \\
\hline $\begin{array}{l}\text { tert-Amyl methyl ether } \\
\text { (TAME) }\end{array}$ & $994-05-8$ & 147 & 2.0 & .04 & $.088 \mathrm{E}$ & ND & -- & -- \\
\hline 1,2,3,5-Tetramethylbenzene & $527-53-7$ & 147 & 1.4 & .18 & $.072 \mathrm{E}$ & ND & -- & -- \\
\hline Styrene $^{4}$ & $100-42-5$ & 147 & 1.4 & .042 & $.050 \mathrm{E}$ & ND & MCL & 100 \\
\hline 1-Methylnaphthalene & $90-12-0$ & 145 & .7 & .5 & $.022 \mathrm{E}$ & ND & -- & -- \\
\hline 2-Methylnaphthalene ${ }^{4}$ & $91-57-6$ & 145 & .7 & .5 & $.035 \mathrm{E}$ & ND & HBSL & 30 \\
\hline Isopropylbenzene & $98-82-8$ & 147 & .7 & .038 & $.022 \mathrm{E}$ & ND & HBSL & 700 \\
\hline$n$-Butylbenzene & $104-51-8$ & 147 & .7 & .14 & $.016 \mathrm{E}$ & ND & -- & -- \\
\hline 1,2,3,4-Tetramethylbenzene & $488-23-3$ & 147 & ND & .14 & ND & ND & -- & -- \\
\hline 2,6-Dimethylnaphthalene & $581-42-0$ & 145 & ND & .5 & ND & ND & -- & -- \\
\hline Diisopropyl ether (DIPE) & $108-20-3$ & 147 & ND & .1 & ND & ND & -- & -- \\
\hline Naphthalene ${ }^{5}$ & $91-20-3$ & 147 & ND & .5 & ND & ND & -- & -- \\
\hline$p$-Isopropyltoluene ${ }^{5}$ & $99-87-6$ & 147 & ND & .08 & ND & ND & -- & -- \\
\hline sec-Butylbenzene & $135-98-8$ & 147 & ND & .06 & ND & ND & -- & -- \\
\hline $\begin{array}{l}\text { tert-Amyl alcohol } \\
\text { (2-Methyl-2-butanol) }\end{array}$ & $75-85-4$ & 145 & ND & 1 & ND & ND & -- & -- \\
\hline
\end{tabular}


Appendix 1. Summary statistics and human-health benchmarks for anthropogenic organic compounds analyzed in source-water samples collected during the first phase of sampling, October 2002-March 2004. - Continued

[Compounds within each primary-use category are listed in order from highest to lowest detection frequency; CASRN, Chemical Abstracts Service Registry Number; E, estimated; AHTN, acetyl hexamethyl tetrahydronaphthalene; HHCB, hexahydrohexamethylcyclopentabenzopyran; MCPA, 2-methyl-4-chlorophenoxyacetic acid; MCL, Maximum Contaminant Level; HBSL, Health-Based Screening Level; ND, not detected; $\mu \mathrm{g} / \mathrm{L}$, micrograms per liter; --, no data; $\mathrm{R}$, removed from data set; $\mathrm{C}$, censored]

\begin{tabular}{|c|c|c|c|c|c|c|c|c|}
\hline $\begin{array}{c}\text { Compound } \\
\text { (other name or abbreviation) }\end{array}$ & CASRN ${ }^{1}$ & $\begin{array}{c}\text { Number } \\
\text { of } \\
\text { samples }\end{array}$ & $\begin{array}{r}\text { Detection } \\
\text { frequency } \\
\text { (percent) }\end{array}$ & $\begin{array}{c}\text { Laboratory } \\
\text { reporting level } \\
(\mu \mathrm{g} / \mathrm{L})\end{array}$ & $\begin{array}{c}\text { Maximum } \\
\text { detected } \\
\text { concentration } \\
(\mu \mathrm{g} / \mathrm{L})\end{array}$ & $\begin{array}{c}\text { Detection } \\
\text { frequency at } \\
0.1 \mu \mathrm{g} / \mathrm{L} \text { assess- } \\
\text { ment level }\end{array}$ & $\begin{array}{c}\text { Type of } \\
\text { human-health } \\
\text { benchmark }^{2}\end{array}$ & $\begin{array}{c}\text { Human-health } \\
\text { benchmark } \\
(\mu \mathrm{g} / \mathrm{L})\end{array}$ \\
\hline \multicolumn{9}{|c|}{ Gasoline hydrocarbons, oxygenates, and oxygenate degradates-Continued } \\
\hline Ethyl tert-butyl ether (ETBE) & $637-92-3$ & 147 & ND & 0.03 & ND & ND & -- & -- \\
\hline tert-Butylbenzene & $98-06-6$ & 147 & ND & .08 & ND & ND & -- & -- \\
\hline \multicolumn{9}{|c|}{ Herbicides and herbicide degradates } \\
\hline Simazine & $122-34-9$ & 146 & 67.1 & 0.005 & 3.23 & 28.1 & MCL & 4 \\
\hline Atrazine & $1912-24-9$ & 146 & 63.7 & .007 & 20.1 & 26.7 & MCL & 3 \\
\hline Deethylatrazine $^{5}$ (DEA) & $6190-65-4$ & 147 & 52.4 & .014 & $.54 \mathrm{E}$ & 10.9 & -- & -- \\
\hline Metolachlor ${ }^{5}$ & $51218-45-2$ & 146 & 51.4 & .006 & 2.93 & 8.8 & HBSL & 700 \\
\hline Prometon & $1610-18-0$ & 146 & 49.3 & .01 & .054 & ND & HBSL & 400 \\
\hline Deisopropylatrazine (DIA) & $1007-28-9$ & 145 & 49.0 & .08 & .40 & 4.1 & -- & -- \\
\hline $2,4-\mathrm{D}$ & $94-75-7$ & 145 & 42.8 & .038 & 4.78 & 15.9 & MCL & 70 \\
\hline 3,4-Dichloroaniline & $95-76-1$ & 146 & 40.4 & .0045 & .06 & ND & -- & -- \\
\hline 2-Hydroxyatrazine & $2163-68-0$ & 145 & 40.0 & .032 & $1.65 \mathrm{E}$ & 22.1 & HBSL & 70 \\
\hline Diuron $^{4}$ & $330-54-1$ & 145 & 30.3 & .016 & .44 & 4.1 & HBSL & ${ }^{2} 2$ \\
\hline MCPA & $94-74-6$ & 145 & 21.4 & .07 & .47 & 4.8 & HBSL & 30 \\
\hline Alachlor & $15972-60-8$ & 146 & 15.1 & .005 & .087 & ND & MCL & 2 \\
\hline Triclopyr & $55335-06-3$ & 145 & 12.4 & .026 & .21 & 1.4 & HBSL & 400 \\
\hline Acetochlor & $34256-82-1$ & 146 & 12.3 & .006 & 4.32 & 3.4 & HBSL & ${ }^{2} 1$ \\
\hline Bentazon & $25057-89-0$ & 145 & 11.7 & .024 & $.10 \mathrm{E}$ & .7 & HBSL & 200 \\
\hline Terbuthylazine & $5915-41-3$ & 146 & 11.6 & .0083 & .017 & ND & HBSL & 2 \\
\hline Tebuthiuron & $34014-18-1$ & 147 & 10.9 & .026 & .028 & ND & HBSL & 1,000 \\
\hline Pendimethalin & $40487-42-1$ & 146 & 8.9 & .022 & .038 & ND & HBSL & 70 \\
\hline Imazaquin & $81335-37-7$ & 145 & 8.3 & .036 & $.15 \mathrm{E}$ & .7 & HBSL & 2,000 \\
\hline Metribuzin $^{5}$ & 21087-64-9 & 146 & 8.2 & .028 & .078 & ND & HBSL & 90 \\
\hline Dicamba & 1918-00-9 & 145 & 6.9 & .036 & .67 & 2.8 & HBSL & 3,000 \\
\hline 2,4-D methyl ester & $1928-38-7$ & 145 & 5.5 & .19 & .65 & 3.4 & -- & -- \\
\hline Imazethapyr & $81335-77-5$ & 145 & 5.5 & .038 & $.13 \mathrm{E}$ & 1.4 & HBSL & 2,000 \\
\hline
\end{tabular}


Appendix 1. Summary statistics and human-health benchmarks for anthropogenic organic compounds analyzed in source-water samples collected during the first phase of sampling, October 2002-March 2004. - Continued

[Compounds within each primary-use category are listed in order from highest to lowest detection frequency; CASRN, Chemical Abstracts Service Registry Number; E, estimated; AHTN, acetyl hexamethyl tetrahydronaphthalene; HHCB, hexahydrohexamethylcyclopentabenzopyran; MCPA, 2-methyl-4-chlorophenoxyacetic acid; MCL, Maximum Contaminant Level; HBSL, Health-Based Screening Level; ND, not detected; $\mu \mathrm{g} / \mathrm{L}$, micrograms per liter; --, no data; R, removed from data set; $\mathrm{C}$, censored]

\begin{tabular}{|c|c|c|c|c|c|c|c|c|}
\hline $\begin{array}{c}\text { Compound } \\
\text { (other name or abbreviation) }\end{array}$ & CASRN $^{1}$ & $\begin{array}{c}\text { Number } \\
\text { of } \\
\text { samples }\end{array}$ & $\begin{array}{c}\text { Detection } \\
\text { frequency } \\
\text { (percent) }\end{array}$ & $\begin{array}{c}\text { Laboratory } \\
\text { reporting level } \\
(\mu \mathrm{g} / \mathrm{L})\end{array}$ & $\begin{array}{c}\text { Maximum } \\
\text { detected } \\
\text { concentration } \\
(\mu \mathrm{g} / \mathrm{L})\end{array}$ & $\begin{array}{c}\text { Detection } \\
\text { frequency at } \\
0.1 \mu \mathrm{g} / \mathrm{L} \text { assess- } \\
\text { ment level }\end{array}$ & $\begin{array}{c}\text { Type of } \\
\text { human-health } \\
\text { benchmark }^{2}\end{array}$ & $\begin{array}{l}\text { Human-health } \\
\text { benchmark } \\
(\mu \mathrm{g} / \mathrm{L})\end{array}$ \\
\hline \multicolumn{9}{|c|}{ Herbicides and herbicide degradates - Continued } \\
\hline Propyzamide & $23950-58-5$ & 146 & 5.5 & 0.004 & 0.010 & ND & HBSL & ${ }^{2} 1$ \\
\hline Hexazinone & $51235-04-2$ & 80 & 8.8 & .026 & .018 & ND & HBSL & 400 \\
\hline Chlorimuron-ethyl & $90982-32-4$ & 145 & 4.1 & .032 & $.20 \mathrm{E}$ & 0.7 & HBSL & 600 \\
\hline 4-Chloro-2-methylphenol & $1570-64-5$ & 146 & 4.1 & .005 & $.013 \mathrm{E}$ & ND & -- & -- \\
\hline Flumetsulam & $98967-40-9$ & 145 & 3.4 & .04 & $.052 \mathrm{E}$ & ND & HBSL & 7,000 \\
\hline Bromacil & $314-40-9$ & 145 & 2.8 & .018 & $.093 \mathrm{E}$ & ND & HBSL & 70 \\
\hline Dichlorprop & $120-36-5$ & 145 & 2.8 & .036 & .070 & ND & HBSL & 300 \\
\hline Sulfometuron-methyl & $74222-97-2$ & 145 & 2.8 & .09 & .024 & ND & -- & -- \\
\hline 2-Ethyl-6-methylaniline & 24549-06-2 & 146 & 2.1 & .01 & $.002 \mathrm{E}$ & ND & -- & -- \\
\hline Clopyralid & $1702-17-6$ & 145 & 2.1 & .067 & .046 & ND & -- & -- \\
\hline Metsulfuron methyl ${ }^{4}$ & $74223-64-6$ & 145 & 2.1 & .067 & $.09 \mathrm{E}$ & ND & HBSL & 2,000 \\
\hline Dacthal & $1861-32-1$ & 146 & 2.1 & .014 & $.002 \mathrm{E}$ & ND & HBSL & 70 \\
\hline Trifluralin & $1582-09-8$ & 146 & 2.1 & .009 & $.005 \mathrm{E}$ & ND & HBSL & 20 \\
\hline Siduron & $1982-49-6$ & 145 & 1.4 & .02 & $.013 \mathrm{E}$ & ND & -- & -- \\
\hline Acifluorfen & $50594-66-6$ & 145 & .7 & .028 & .011 & ND & HBSL & 90 \\
\hline Bromoxynil & $1689-84-5$ & 145 & .7 & .044 & $.004 \mathrm{E}$ & $\mathrm{ND}$ & HBSL & 10 \\
\hline $\begin{array}{l}\text { Deethyldeisopropyl atrazine } \\
\text { (DDA) }\end{array}$ & $3397-62-4$ & 144 & .7 & .04 & $.16 \mathrm{E}$ & .7 & -- & -- \\
\hline Dinoseb & $88-85-7$ & 145 & .7 & .038 & $.004 \mathrm{E}$ & ND & MCL & 7 \\
\hline Diphenamid & $957-51-7$ & 145 & .7 & .01 & $.010 \mathrm{E}$ & ND & HBSL & 200 \\
\hline Nicosulfuron & 111991-09-4 & 145 & .7 & .04 & $.087 \mathrm{E}$ & ND & HBSL & 9,000 \\
\hline Norflurazon & $27314-13-2$ & 145 & .7 & .02 & $.004 \mathrm{E}$ & ND & HBSL & 10 \\
\hline Oryzalin & $19044-88-3$ & 145 & .7 & .023 & $.065 \mathrm{E}$ & ND & HBSL & 24 \\
\hline Picloram & $1918-02-1$ & 145 & .7 & .032 & .16 & .7 & MCL & 500 \\
\hline Terbacil & $5902-51-2$ & 145 & .7 & .026 & $.01 \mathrm{E}$ & ND & HBSL & 90 \\
\hline $\begin{array}{l}\text { Metolachlor ethane sulfonic } \\
\text { acid }^{8}\end{array}$ & -- & 39 & 69.2 & .02 & 2.07 & 66.7 & -- & -- \\
\hline
\end{tabular}


Appendix 1. Summary statistics and human-health benchmarks for anthropogenic organic compounds analyzed in source-water samples collected during the first phase of sampling, October 2002-March 2004. - Continued

[Compounds within each primary-use category are listed in order from highest to lowest detection frequency; CASRN, Chemical Abstracts Service Registry Number; E, estimated; AHTN, acetyl hexamethyl tetrahydronaphthalene; HHCB, hexahydrohexamethylcyclopentabenzopyran; MCPA, 2-methyl-4-chlorophenoxyacetic acid; MCL, Maximum Contaminant Level; HBSL, Health-Based Screening Level; ND, not detected; $\mu \mathrm{g} / \mathrm{L}$, micrograms per liter; --, no data; R, removed from data set; $\mathrm{C}$, censored]

\begin{tabular}{|c|c|c|c|c|c|c|c|c|}
\hline $\begin{array}{c}\text { Compound } \\
\text { (other name or abbreviation) }\end{array}$ & CASRN $^{1}$ & $\begin{array}{c}\text { Number } \\
\text { of } \\
\text { samples }\end{array}$ & $\begin{array}{c}\text { Detection } \\
\text { frequency } \\
\text { (percent) }\end{array}$ & $\begin{array}{c}\text { Laboratory } \\
\text { reporting level } \\
(\mu \mathrm{g} / \mathrm{L})\end{array}$ & $\begin{array}{c}\text { Maximum } \\
\text { detected } \\
\text { concentration } \\
(\mu \mathrm{g} / \mathrm{L})\end{array}$ & $\begin{array}{c}\text { Detection } \\
\text { frequency at } \\
0.1 \mu \mathrm{g} / \mathrm{L} \text { assess- } \\
\text { ment level }\end{array}$ & $\begin{array}{c}\text { Type of } \\
\text { human-health } \\
\text { benchmark }^{2}\end{array}$ & $\begin{array}{l}\text { Human-health } \\
\text { benchmark } \\
\text { ( } \mu \mathrm{g} / \mathrm{L})\end{array}$ \\
\hline \multicolumn{9}{|c|}{ Herbicides and herbicide degradates - Continued } \\
\hline Metolachlor oxanilic acid ${ }^{8}$ & -- & 39 & 66.7 & 0.02 & 1.47 & 43.6 & -- & -- \\
\hline Alachlor ethane sulfonic acid ${ }^{8}$ & -- & 39 & 59.0 & .02 & .24 & 33.3 & -- & -- \\
\hline $\begin{array}{l}\text { Acetochlor ethane sulfonic } \\
\text { acid }^{8}\end{array}$ & -- & 39 & 41.0 & .02 & 1.42 & 35.9 & -- & -- \\
\hline Alachlor oxanilic acid ${ }^{8}$ & -- & 39 & 41.0 & .02 & .13 & 7.7 & -- & -- \\
\hline Acetochlor oxanilic acid ${ }^{8}$ & -- & 39 & 38.5 & .02 & 1.74 & 30.8 & -- & -- \\
\hline Acetochlor sulfynilacetic acid ${ }^{8}$ & -- & 39 & 25.6 & .02 & 1.22 & 17.9 & -- & -- \\
\hline $\begin{array}{l}\text { Dimethenamid ethane sulfonic } \\
\operatorname{acid}^{8}\end{array}$ & -- & 39 & 12.8 & .02 & .11 & 2.6 & -- & -- \\
\hline Alachlor sulfynilacetic acid ${ }^{8}$ & 140939-16-8 & 39 & 5.1 & .02 & .11 & 2.6 & -- & -- \\
\hline Dimethenamid oxanilic acid ${ }^{8}$ & -- & 39 & 2.6 & .02 & .05 & ND & -- & -- \\
\hline Propachlor ${ }^{8}$ & $1918-16-7$ & 0 & -- & .02 & -- & -- & HBSL & ${ }^{2} 1$ \\
\hline $\begin{array}{l}\text { 2-Chloro-2,6-diethylaceta- } \\
\text { nilide }\end{array}$ & 6967-29-9 & 146 & ND & .0065 & ND & ND & -- & -- \\
\hline Benfluralin & $1861-40-1$ & 146 & ND & .01 & ND & ND & HBSL & 4 \\
\hline Cycloate & $1134-23-2$ & 145 & $\mathrm{ND}$ & .014 & ND & ND & HBSL & 40 \\
\hline Prometryn & $7287-19-6$ & 146 & ND & .0059 & ND & ND & HBSL & 300 \\
\hline Linuron $^{5}$ & $330-55-2$ & 145 & ND & .014 & ND & ND & HBSL & 5 \\
\hline МСРB & $94-81-5$ & 145 & ND & .1 & ND & ND & HBSL & 100 \\
\hline 2,4-DB & $94-82-6$ & 145 & ND & .02 & ND & ND & HBSL & 200 \\
\hline Fluometuron & $2164-17-2$ & 145 & ND & .016 & ND & ND & HBSL & 4 \\
\hline Propham & $122-42-9$ & 145 & ND & .03 & ND & ND & HBSL & 100 \\
\hline Neburon & $555-37-3$ & 145 & ND & .012 & ND & ND & -- & -- \\
\hline Fenuron & $101-42-8$ & 145 & ND & .1 & ND & ND & -- & -- \\
\hline Dacthal monoacid & $887-54-7$ & 145 & ND & .028 & ND & ND & -- & -- \\
\hline Chloramben, methyl ester & $7286-84-2$ & 145 & ND & .024 & ND & ND & -- & -- \\
\hline Dimethenamid & $87674-68-8$ & 6 & ND & .02 & ND & ND & -- & -- \\
\hline
\end{tabular}


Appendix 1. Summary statistics and human-health benchmarks for anthropogenic organic compounds analyzed in source-water samples collected during the first phase of sampling, October 2002-March 2004. - Continued

[Compounds within each primary-use category are listed in order from highest to lowest detection frequency; CASRN, Chemical Abstracts Service Registry Number; E, estimated; AHTN, acetyl hexamethyl tetrahydronaphthalene; HHCB, hexahydrohexamethylcyclopentabenzopyran; MCPA, 2-methyl-4-chlorophenoxyacetic acid; MCL, Maximum Contaminant Level; HBSL, Health-Based Screening Level; ND, not detected; $\mu \mathrm{g} / \mathrm{L}$, micrograms per liter; --, no data; R, removed from data set; $\mathrm{C}$, censored]

\begin{tabular}{|c|c|c|c|c|c|c|c|c|}
\hline $\begin{array}{c}\text { Compound } \\
\text { (other name or abbreviation) }\end{array}$ & CASRN ${ }^{1}$ & $\begin{array}{l}\text { Number } \\
\text { of } \\
\text { samples }\end{array}$ & $\begin{array}{c}\text { Detection } \\
\text { frequency } \\
\text { (percent) }\end{array}$ & $\begin{array}{c}\text { Laboratory } \\
\text { reporting level } \\
(\mu \mathrm{g} / \mathrm{L})\end{array}$ & $\begin{array}{c}\text { Maximum } \\
\text { detected } \\
\text { concentration } \\
(\mu \mathrm{g} / \mathrm{L})\end{array}$ & $\begin{array}{c}\text { Detection } \\
\text { frequency at } \\
0.1 \mu \mathrm{g} / \mathrm{L} \text { assess- } \\
\text { ment level }\end{array}$ & $\begin{array}{c}\text { Type of } \\
\text { human-health } \\
\text { benchmark }^{2}\end{array}$ & $\begin{array}{c}\text { Human-health } \\
\text { benchmark } \\
(\mu \mathrm{g} / \mathrm{L})\end{array}$ \\
\hline \multicolumn{9}{|c|}{ Herbicides and herbicide degradates-Continued } \\
\hline $\begin{array}{l}\text { 3(4-Chlorophenyl)-1-methyl } \\
\text { urea }\end{array}$ & $5352-88-5$ & 145 & ND & 0.036 & ND & ND & -- & -- \\
\hline Bensulfuron-methyl & $83055-99-6$ & 145 & ND & .018 & ND & ND & HBSL & 1,000 \\
\hline $\begin{array}{l}\text { Flufenacet ethane sulfonic } \\
\text { acid }^{8}\end{array}$ & -- & 39 & ND & .02 & ND & ND & -- & -- \\
\hline Flufenacet ${ }^{8}$ & $142459-58-3$ & 6 & ND & .02 & ND & ND & -- & -- \\
\hline Flufenacet oxanilic acid ${ }^{8}$ & -- & 39 & ND & .02 & ND & ND & -- & -- \\
\hline $\begin{array}{l}\text { Propachlor ethane sulfonic } \\
\operatorname{acid}^{8}\end{array}$ & -- & 39 & ND & .02 & ND & ND & -- & -- \\
\hline Propachlor oxanilic acid ${ }^{8}$ & -- & 39 & ND & .02 & ND & ND & -- & -- \\
\hline $\begin{array}{l}\text { Alachlor ethane sulfonic acid } \\
\text { 2nd amide }\end{array}$ & -- & 11 & ND & .02 & ND & ND & -- & -- \\
\hline $\begin{array}{l}\text { Acetochlor/metolachlor ethane } \\
\text { sulfonic acid } 2 \text { nd } \text { amide }^{8}\end{array}$ & -- & 6 & ND & .02 & ND & ND & -- & -- \\
\hline 2,6-Diethylaniline & $579-66-8$ & 146 & ND & .006 & ND & ND & -- & -- \\
\hline \multicolumn{9}{|c|}{ Insecticide and insecticide degradates } \\
\hline Diazinon & $333-41-5$ & 146 & 39.0 & 0.005 & 0.086 & ND & HBSL & 1 \\
\hline Fipronil & $120068-37-3$ & 146 & 29.5 & .016 & .016 & ND & -- & -- \\
\hline Carbaryl & $63-25-2$ & 145 & 15.2 & .018 & $.065 \mathrm{E}$ & ND & HBSL & ${ }^{2} 40$ \\
\hline Desulfinylfipronil & -- & 146 & 7.5 & .012 & .006 & ND & -- & -- \\
\hline 1-Naphthol & $90-15-3$ & 146 & 6.2 & .0882 & $.014 \mathrm{E}$ & ND & -- & -- \\
\hline Chlorpyrifos & $2921-88-2$ & 146 & 6.2 & .005 & .008 & ND & HBSL & 2 \\
\hline Fipronil sulfide & $120067-83-6$ & 146 & 6.2 & .013 & .007 & ND & -- & -- \\
\hline Dichlorvos & $62-73-7$ & 146 & 4.1 & .006 & .012 & ND & HBSL & .4 \\
\hline Imidacloprid & $138261-41-3$ & 145 & 2.8 & .023 & .037 & ND & HBSL & 400 \\
\hline Propoxur & $114-26-1$ & 145 & 2.8 & .008 & $.006 \mathrm{E}$ & ND & HBSL & ${ }^{29}$ \\
\hline Carbofuran & $1563-66-2$ & 145 & 2.1 & .016 & .012 & ND & MCL & 40 \\
\hline
\end{tabular}


Appendix 1. Summary statistics and human-health benchmarks for anthropogenic organic compounds analyzed in source-water samples collected during the first phase of sampling, October 2002-March 2004. - Continued

[Compounds within each primary-use category are listed in order from highest to lowest detection frequency; CASRN, Chemical Abstracts Service Registry Number; E, estimated; AHTN, acetyl hexamethyl tetrahydronaphthalene; HHCB, hexahydrohexamethylcyclopentabenzopyran; MCPA, 2-methyl-4-chlorophenoxyacetic acid; MCL, Maximum Contaminant Level; HBSL, Health-Based Screening Level; ND, not detected; $\mu \mathrm{g} / \mathrm{L}$, micrograms per liter; --, no data; $\mathrm{R}$, removed from data set; $\mathrm{C}$, censored]

\begin{tabular}{|c|c|c|c|c|c|c|c|c|}
\hline $\begin{array}{c}\text { Compound } \\
\text { (other name or abbreviation) }\end{array}$ & CASRN ${ }^{1}$ & $\begin{array}{c}\text { Number } \\
\text { of } \\
\text { samples }\end{array}$ & $\begin{array}{c}\text { Detection } \\
\text { frequency } \\
\text { (percent) }\end{array}$ & $\begin{array}{c}\text { Laboratory } \\
\text { reporting level } \\
(\mu \mathrm{g} / \mathrm{L})\end{array}$ & $\begin{array}{c}\text { Maximum } \\
\text { detected } \\
\text { concentration } \\
(\mu \mathrm{g} / \mathrm{L})\end{array}$ & $\begin{array}{c}\text { Detection } \\
\text { frequency at } \\
0.1 \mu \mathrm{g} / \mathrm{L} \text { assess- } \\
\text { ment level }\end{array}$ & $\begin{array}{c}\text { Type of } \\
\text { human-health } \\
\text { benchmark }^{2}\end{array}$ & $\begin{array}{l}\text { Human-health } \\
\text { benchmark } \\
(\mu \mathrm{g} / \mathrm{L})\end{array}$ \\
\hline \multicolumn{9}{|c|}{ Insecticide and insecticide degradates-Continued } \\
\hline Malathion & $121-75-5$ & 146 & 2.1 & 0.027 & $0.018 \mathrm{E}$ & ND & HBSL & 50 \\
\hline Dimethoate & $60-51-5$ & 146 & 1.4 & .0061 & $.009 \mathrm{E}$ & ND & HBSL & 2 \\
\hline Fipronil sulfone & $120068-36-2$ & 146 & 1.4 & .024 & $.008 \mathrm{E}$ & ND & -- & -- \\
\hline Phosmet & $732-11-6$ & 141 & .7 & .0079 & $.007 \mathrm{E}$ & ND & HBSL & 8 \\
\hline Azinphos-methyl & $86-50-0$ & 146 & .7 & .05 & $.016 \mathrm{E}$ & ND & HBSL & 10 \\
\hline Dieldrin & $60-57-1$ & 146 & .7 & .009 & $.004 \mathrm{E}$ & ND & HBSL & ${ }^{2} .002$ \\
\hline 3-Hydroxycarbofuran & $16655-82-6$ & 145 & ND & .008 & ND & ND & -- & -- \\
\hline 3-Ketocarbofuran & 16709-30-1 & 145 & ND & 1.5 & ND & ND & -- & -- \\
\hline Aldicarb & $116-06-3$ & 145 & ND & .15 & ND & ND & HBSL & ${ }^{9} 9$ \\
\hline Aldicarb sulfoxide & $1646-87-3$ & 145 & ND & .1 & ND & ND & HBSL & ${ }^{97}$ \\
\hline Aldicarb sulfone & $1646-88-4$ & 145 & ND & .018 & ND & ND & HBSL & ${ }^{97}$ \\
\hline Azinphos-methyl-oxon & $961-22-8$ & 145 & ND & .042 & ND & ND & -- & -- \\
\hline Bendiocarb & $22781-23-3$ & 145 & ND & .08 & ND & ND & HBSL & 9 \\
\hline Chlorpyrifos, oxygen analog & $5598-15-2$ & 146 & ND & .0562 & ND & ND & -- & -- \\
\hline cis-Permethrin & $54774-45-7$ & 146 & ND & .006 & ND & ND & HBSL & ${ }^{2,10} 4$ \\
\hline Cyfluthrin & $68359-37-5$ & 146 & ND & .053 & ND & ND & HBSL & 200 \\
\hline Cypermethrin & $52315-07-8$ & 146 & ND & .046 & ND & ND & HBSL & 40 \\
\hline Desulfinylfipronil amide & -- & 146 & ND & .029 & ND & ND & -- & -- \\
\hline Diazinon, oxygen analog & $962-58-3$ & 146 & ND & .006 & ND & ND & -- & -- \\
\hline Dicrotophos & $141-66-2$ & 144 & ND & .0843 & ND & ND & HBSL & .05 \\
\hline Ethion & $563-12-2$ & 146 & ND & .016 & ND & ND & HBSL & 4 \\
\hline Ethion monoxon & $17356-42-2$ & 146 & ND & .021 & ND & ND & -- & -- \\
\hline Fenamiphos & $22224-92-6$ & 146 & ND & .029 & ND & ND & HBSL & .7 \\
\hline Fenamiphos sulfone & $31972-44-8$ & 146 & ND & .053 & ND & ND & -- & -- \\
\hline Fenamiphos sulfoxide & $31972-43-7$ & 143 & ND & .04 & ND & ND & -- & -- \\
\hline Fonofos & $944-22-9$ & 146 & ND & .0053 & ND & ND & HBSL & 10 \\
\hline
\end{tabular}


Appendix 1. Summary statistics and human-health benchmarks for anthropogenic organic compounds analyzed in source-water samples collected during the first phase of sampling, October 2002-March 2004. - Continued

[Compounds within each primary-use category are listed in order from highest to lowest detection frequency; CASRN, Chemical Abstracts Service Registry Number; E, estimated; AHTN, acetyl hexamethyl tetrahydronaphthalene; HHCB, hexahydrohexamethylcyclopentabenzopyran; MCPA, 2-methyl-4-chlorophenoxyacetic acid; MCL, Maximum Contaminant Level; HBSL, Health-Based Screening Level; ND, not detected; $\mu \mathrm{g} / \mathrm{L}$, micrograms per liter; --, no data; R, removed from data set; $\mathrm{C}$, censored]

\begin{tabular}{|c|c|c|c|c|c|c|c|c|}
\hline $\begin{array}{c}\text { Compound } \\
\text { (other name or abbreviation) }\end{array}$ & CASRN ${ }^{1}$ & $\begin{array}{c}\text { Number } \\
\text { of } \\
\text { samples }\end{array}$ & $\begin{array}{c}\text { Detection } \\
\text { frequency } \\
\text { (percent) }\end{array}$ & $\begin{array}{c}\text { Laboratory } \\
\text { reporting level } \\
(\mu \mathrm{g} / \mathrm{L})\end{array}$ & $\begin{array}{c}\text { Maximum } \\
\text { detected } \\
\text { concentration } \\
(\mu \mathrm{g} / \mathrm{L})\end{array}$ & $\begin{array}{c}\text { Detection } \\
\text { frequency at } \\
0.1 \mu \mathrm{g} / \mathrm{L} \text { assess- } \\
\text { ment level }\end{array}$ & $\begin{array}{c}\text { Type of } \\
\text { human-health } \\
\text { benchmark }^{2}\end{array}$ & $\begin{array}{l}\text { Human-health } \\
\text { benchmark } \\
(\mu \mathrm{g} / \mathrm{L})\end{array}$ \\
\hline \multicolumn{9}{|c|}{ Insecticide and insecticide degradates-Continued } \\
\hline Fonofos oxygen analog & $944-21-8$ & 146 & ND & 0.0029 & ND & ND & -- & -- \\
\hline Isofenphos & $25311-71-1$ & 146 & ND & .011 & ND & ND & HBSL & 6 \\
\hline Malaoxon & $1634-78-2$ & 146 & ND & .039 & ND & ND & -- & -- \\
\hline Methidathion & $950-37-8$ & 146 & ND & .0087 & ND & ND & HBSL & 1 \\
\hline Methiocarb & $2032-65-7$ & 145 & ND & .034 & ND & ND & HBSL & 40 \\
\hline Methomyl & $16752-77-5$ & 145 & ND & .07 & ND & ND & HBSL & 200 \\
\hline Oxamyl & $23135-22-0$ & 145 & ND & .05 & ND & ND & MCL & 200 \\
\hline Paraoxon-methyl & $950-35-6$ & 146 & ND & .019 & ND & ND & -- & -- \\
\hline Parathion-methyl & $298-00-0$ & 146 & ND & .015 & ND & ND & HBSL & 1 \\
\hline Phorate & $298-02-2$ & 146 & ND & .055 & ND & ND & HBSL & 4 \\
\hline Phorate oxon & $2600-69-3$ & 146 & ND & .027 & ND & ND & -- & -- \\
\hline Phosmet oxon & $3735-33-9$ & 138 & ND & .0511 & ND & ND & -- & -- \\
\hline Terbufos & 13071-79-9 & 146 & ND & .017 & ND & ND & HBSL & .4 \\
\hline $\begin{array}{l}\text { Terbufos-oxygen-analogue } \\
\text { sulfone }\end{array}$ & $56070-15-6$ & 146 & ND & .045 & ND & ND & -- & -- \\
\hline \multicolumn{9}{|c|}{ Manufacturing additives } \\
\hline Tri(2-chloroethyl)phosphate ${ }^{4}$ & $115-96-8$ & 145 & 34.5 & 0.5 & $0.14 \mathrm{E}$ & 8.3 & -- & -- \\
\hline $\begin{array}{l}\text { Tris(dichlorisopropyl)phos- } \\
\text { phate }\end{array}$ & $13674-87-8$ & 145 & 25.5 & .5 & $.12 \mathrm{E}$ & 3.4 & -- & -- \\
\hline Tributyl phosphate & $126-73-8$ & 118 & 20.3 & .5 & $.22 \mathrm{E}$ & 7.6 & -- & -- \\
\hline Tri(2-butoxyethyl)phosphate & $78-51-3$ & 145 & 18.6 & .5 & .93 & 18.6 & -- & -- \\
\hline Triphenyl phosphate & $115-86-6$ & 145 & 15.9 & .5 & $.077 \mathrm{E}$ & ND & -- & -- \\
\hline Bisphenol A & $80-05-7$ & 145 & $\mathrm{C}$ & 1 & $\mathrm{C}$ & $\mathrm{C}$ & HBSL & 400 \\
\hline 5-Methyl-1H-benzotriazole & $136-85-6$ & 145 & .7 & 2 & $.36 \mathrm{E}$ & .7 & -- & -- \\
\hline
\end{tabular}


Appendix 1. Summary statistics and human-health benchmarks for anthropogenic organic compounds analyzed in source-water samples collected during the first phase of sampling, October 2002-March 2004.-Continued

[Compounds within each primary-use category are listed in order from highest to lowest detection frequency; CASRN, Chemical Abstracts Service Registry Number; E, estimated; AHTN, acetyl hexamethyl tetrahydronaphthalene; HHCB, hexahydrohexamethylcyclopentabenzopyran; MCPA, 2-methyl-4-chlorophenoxyacetic acid; MCL, Maximum Contaminant Level; HBSL, Health-Based Screening Level; ND, not detected; $\mu \mathrm{g} / \mathrm{L}$, micrograms per liter; --, no data; R, removed from data set; $\mathrm{C}$, censored]

\begin{tabular}{|c|c|c|c|c|c|c|c|c|}
\hline $\begin{array}{c}\text { Compound } \\
\text { (other name or abbreviation) }\end{array}$ & CASRN ${ }^{1}$ & $\begin{array}{l}\text { Number } \\
\text { of } \\
\text { samples }\end{array}$ & $\begin{array}{l}\text { Detection } \\
\text { frequency } \\
\text { (percent) }\end{array}$ & $\begin{array}{c}\text { Laboratory } \\
\text { reporting level } \\
(\mu \mathrm{g} / \mathrm{L})\end{array}$ & $\begin{array}{c}\text { Maximum } \\
\text { detected } \\
\text { concentration } \\
(\mu \mathrm{g} / \mathrm{L}) \\
\end{array}$ & $\begin{array}{c}\text { Detection } \\
\text { frequency at } \\
0.1 \mu \mathrm{g} / \mathrm{L} \text { assess- } \\
\text { ment level }\end{array}$ & $\begin{array}{c}\text { Type of } \\
\text { human-health } \\
\text { benchmark }^{2}\end{array}$ & $\begin{array}{l}\text { Human-health } \\
\text { benchmark } \\
(\mu \mathrm{g} / \mathrm{L})\end{array}$ \\
\hline \multicolumn{9}{|c|}{ Organic synthesis compounds } \\
\hline Anthraquinone & $84-65-1$ & 146 & 6.2 & 0.5 & $0.11 \mathrm{E}$ & 2.0 & -- & -- \\
\hline Carbazole $^{4}$ & $86-74-8$ & 146 & 2.1 & .5 & $.051 \mathrm{E}$ & ND & -- & -- \\
\hline Carbon disulfide ${ }^{4}$ & $75-15-0$ & 147 & 2.0 & .038 & $.034 \mathrm{E}$ & ND & HBSL & 700 \\
\hline Chloromethane & $74-87-3$ & 147 & 1.4 & .17 & $.10 \mathrm{E}$ & .7 & HBSL & 30 \\
\hline 1,1-Dichloropropene ${ }^{5}$ & $563-58-6$ & 147 & $\mathrm{ND}$ & .026 & ND & ND & -- & -- \\
\hline 1,2,3-Trichlorobenzene & $87-61-6$ & 147 & ND & .18 & ND & ND & -- & -- \\
\hline 1,2,3-Trichloropropane & $96-18-4$ & 147 & ND & .18 & ND & ND & HBSL & 40 \\
\hline 3-Chloro-1-propene & $107-05-1$ & 147 & ND & .5 & ND & ND & -- & -- \\
\hline Acrylonitrile & $107-13-1$ & 147 & ND & .8 & ND & ND & HBSL & .06 \\
\hline $\begin{array}{l}\text { Ethyl methacrylate } \\
\text { (ethyl 2-methyl-2-propano- } \\
\text { ate) }\end{array}$ & $97-63-2$ & 147 & ND & .18 & ND & ND & -- & -- \\
\hline Hexachlorobutadiene $^{5}$ & $87-68-3$ & 147 & ND & .14 & ND & ND & HBSL & 2.9 \\
\hline Iodomethane & $74-88-4$ & 147 & ND & .5 & ND & ND & -- & -- \\
\hline $\begin{array}{l}\text { Methyl acrylate } \\
\text { (methyl-2-propenoate) }\end{array}$ & $96-33-3$ & 147 & ND & 1 & ND & ND & -- & -- \\
\hline $\begin{array}{l}\text { Methyl acrylonitrile } \\
\text { (2-methyl-2-propenenitrile) }\end{array}$ & $126-98-7$ & 147 & ND & .4 & ND & ND & HBSL & .7 \\
\hline $\begin{array}{l}\text { Methyl methacrylate (methyl } \\
\text { 2-methyl-2-propenoate) }\end{array}$ & $80-62-6$ & 147 & ND & .2 & ND & ND & HBSL & 10,000 \\
\hline trans-1,4-Dichloro-2-butene & $110-57-6$ & 147 & ND & .7 & ND & ND & -- & -- \\
\hline Vinyl bromide & $593-60-2$ & 147 & ND & .1 & ND & ND & -- & -- \\
\hline Vinyl chloride & $75-01-4$ & 147 & ND & .08 & ND & ND & MCL & 2 \\
\hline \multicolumn{9}{|c|}{ Pavement- and combustion-derived compounds } \\
\hline Fluoranthene ${ }^{4}$ & $206-44-0$ & 145 & 6.9 & 0.5 & $0.053 \mathrm{E}$ & ND & HBSL & 300 \\
\hline Pyrene ${ }^{4}$ & $129-00-0$ & 145 & 6.9 & .5 & $.049 \mathrm{E}$ & ND & HBSL & 200 \\
\hline Anthracene & $120-12-7$ & 145 & ND & .5 & ND & ND & HBSL & 2,000 \\
\hline
\end{tabular}


Appendix 1. Summary statistics and human-health benchmarks for anthropogenic organic compounds analyzed in source-water samples collected during the first phase of sampling, October 2002-March 2004. - Continued

[Compounds within each primary-use category are listed in order from highest to lowest detection frequency; CASRN, Chemical Abstracts Service Registry Number; E, estimated; AHTN, acetyl hexamethyl tetrahydronaphthalene; HHCB, hexahydrohexamethylcyclopentabenzopyran; MCPA, 2-methyl-4-chlorophenoxyacetic acid; MCL, Maximum Contaminant Level; HBSL, Health-Based Screening Level; ND, not detected; $\mu \mathrm{g} / \mathrm{L}$, micrograms per liter; --, no data; R, removed from data set; $\mathrm{C}$, censored]

\begin{tabular}{|c|c|c|c|c|c|c|c|c|}
\hline $\begin{array}{c}\text { Compound } \\
\text { (other name or abbreviation) }\end{array}$ & CASRN ${ }^{1}$ & $\begin{array}{c}\text { Number } \\
\text { of } \\
\text { samples }\end{array}$ & $\begin{array}{c}\text { Detection } \\
\text { frequency } \\
\text { (percent) }\end{array}$ & $\begin{array}{c}\text { Laboratory } \\
\text { reporting level } \\
(\mu \mathrm{g} / \mathrm{L})\end{array}$ & $\begin{array}{c}\text { Maximum } \\
\text { detected } \\
\text { concentration } \\
(\mu \mathrm{g} / \mathrm{L})\end{array}$ & $\begin{array}{c}\text { Detection } \\
\text { frequency at } \\
0.1 \mu \mathrm{g} / \mathrm{L} \text { assess- } \\
\text { ment level }\end{array}$ & $\begin{array}{c}\text { Type of } \\
\text { human-health } \\
\text { benchmark }^{2}\end{array}$ & $\begin{array}{l}\text { Human-health } \\
\text { benchmark } \\
\text { ( } \mu \mathrm{g} / \mathrm{L})\end{array}$ \\
\hline \multicolumn{9}{|c|}{ Pavement- and combustion-derived compounds-Continued } \\
\hline Benzo[a]pyrene & $50-32-8$ & 145 & ND & 0.5 & ND & ND & MCL & .2 \\
\hline Phenanthrene & $85-01-8$ & 145 & ND & .5 & ND & ND & -- & -- \\
\hline \multicolumn{9}{|c|}{ Personal-care and domestic-use products } \\
\hline $\mathrm{HHCB}^{4}$ & $1222-05-5$ & 145 & 53.1 & 0.5 & $0.26 \mathrm{E}$ & 16.6 & -- & -- \\
\hline $\mathrm{AHTN}^{4}$ & $21145-77-7$ & 145 & 38.6 & .5 & $.15 \mathrm{E}$ & .7 & -- & -- \\
\hline Caffeine & $58-08-2$ & 132 & 31.1 & .018 & .15 & 2.3 & -- & -- \\
\hline $\begin{array}{l}\text { Nonylphenol diethoxylate } \\
\text { (total) (NP2EO) }\end{array}$ & $26027-38-2$ & 144 & 13.8 & 5 & $6.6 \mathrm{E}$ & 13.8 & -- & -- \\
\hline Triethyl citrate (ethyl citrate) & $77-93-0$ & 144 & 13.9 & .5 & $.19 \mathrm{E}$ & .7 & -- & -- \\
\hline $\begin{array}{l}\text { Octylphenol monoethoxylate } \\
\text { (total })^{4}(\mathrm{OP} 2 \mathrm{EO})\end{array}$ & -- & 145 & 11.0 & 1 & $.82 \mathrm{E}$ & 11.0 & -- & -- \\
\hline $\begin{array}{l}\text { Octylphenol diethoxylate } \\
\quad(\text { total })^{4} \text { (OP1EO) }\end{array}$ & $26636-32-8$ & 145 & 8.3 & 1 & $.25 \mathrm{E}$ & 6.2 & -- & -- \\
\hline Indole & $120-72-9$ & 145 & 6.2 & .5 & $.1 \mathrm{E}$ & .7 & -- & -- \\
\hline Triclosan & $3380-34-5$ & 144 & 5.6 & .5 & $.1 \mathrm{E}$ & .7 & -- & -- \\
\hline Methyl salicylate & $119-36-8$ & 145 & 4.1 & .5 & $.39 \mathrm{E}$ & 2.8 & HBSL & 4,000 \\
\hline Menthol & $89-78-1$ & 145 & 2.8 & .5 & $.16 \mathrm{E}$ & .7 & -- & -- \\
\hline Camphor $^{4}$ & $76-22-2$ & 145 & 2.8 & .5 & $.026 \mathrm{E}$ & ND & -- & -- \\
\hline Cotinine & $486-56-6$ & 145 & 2.8 & 1 & $.25 \mathrm{E}$ & 1.4 & -- & -- \\
\hline$d$-Limonene ${ }^{4}$ & $5989-27-5$ & 145 & 1.4 & .5 & $.064 \mathrm{E}$ & ND & -- & -- \\
\hline 4-tert-Octylphenol ${ }^{4}$ & $140-66-9$ & 145 & ND & 1 & ND & ND & -- & -- \\
\hline 4-Cumylphenol & $599-64-4$ & 145 & ND & 1 & ND & ND & -- & -- \\
\hline $\begin{array}{l}\text { 3-tert-Butyl-4-hydroxy anisole } \\
\text { (BHA) }\end{array}$ & $25013-16-5$ & 145 & ND & 5 & ND & ND & -- & -- \\
\hline 4-n-Octylphenol & $1806-26-4$ & 145 & ND & 1 & ND & ND & -- & -- \\
\hline Acetophenone & $98-86-2$ & 145 & ND & .5 & ND & ND & HBSL & 700 \\
\hline Benzophenone & 119-61-9 & 145 & $\mathrm{R}$ & .5 & -- & -- & -- & -- \\
\hline
\end{tabular}


Appendix 1. Summary statistics and human-health benchmarks for anthropogenic organic compounds analyzed in source-water samples collected during the first phase of sampling, October 2002-March 2004.-Continued

[Compounds within each primary-use category are listed in order from highest to lowest detection frequency; CASRN, Chemical Abstracts Service Registry Number; E, estimated; AHTN, acetyl hexamethyl tetrahydronaphthalene; HHCB, hexahydrohexamethylcyclopentabenzopyran; MCPA, 2-methyl-4-chlorophenoxyacetic acid; MCL, Maximum Contaminant Level; HBSL, Health-Based Screening Level; ND, not detected; $\mu \mathrm{g} / \mathrm{L}$, micrograms per liter; --, no data; R, removed from data set; $\mathrm{C}$, censored]

\begin{tabular}{|c|c|c|c|c|c|c|c|c|}
\hline $\begin{array}{c}\text { Compound } \\
\text { (other name or abbreviation) }\end{array}$ & CASRN ${ }^{1}$ & $\begin{array}{c}\text { Number } \\
\text { of } \\
\text { samples }\end{array}$ & $\begin{array}{r}\text { Detection } \\
\text { frequency } \\
\text { (percent) }\end{array}$ & $\begin{array}{c}\text { Laboratory } \\
\text { reporting level } \\
(\mu \mathrm{g} / \mathrm{L})\end{array}$ & $\begin{array}{c}\text { Maximum } \\
\text { detected } \\
\text { concentration } \\
(\mu \mathrm{g} / \mathrm{L})\end{array}$ & $\begin{array}{c}\text { Detection } \\
\text { frequency at } \\
0.1 \mu \mathrm{g} / \mathrm{L} \text { assess- } \\
\text { ment level }\end{array}$ & $\begin{array}{c}\text { Type of } \\
\text { human-health } \\
\text { benchmark }^{2}\end{array}$ & $\begin{array}{c}\text { Human-health } \\
\text { benchmark } \\
(\mu \mathrm{g} / \mathrm{L})\end{array}$ \\
\hline \multicolumn{9}{|c|}{ Personal-care and domestic-use products-Continued } \\
\hline Bromochloromethane & $74-97-5$ & 145 & ND & 0.12 & ND & ND & HBSL & 90 \\
\hline Isoborneol & $124-76-5$ & 145 & ND & .5 & ND & ND & -- & -- \\
\hline Isoquinoline & $119-65-3$ & 145 & ND & .5 & ND & ND & -- & -- \\
\hline $\begin{array}{l}\text { N,N-diethyl-meta-toluamide } \\
\text { (DEET) }\end{array}$ & $134-62-3$ & 145 & $\mathrm{R}$ & .5 & -- & -- & -- & -- \\
\hline Phenol & $108-95-2$ & 145 & $\mathrm{R}$ & .5 & & & HBSL & 2,000 \\
\hline para-Nonylphenol (total) & $84852-15-3$ & 145 & $\mathrm{R}$ & 5 & -- & -- & -- & -- \\
\hline \multicolumn{9}{|c|}{ Plant- or animal-derived biochemicals } \\
\hline Cholesterol & $57-88-5$ & 145 & 16.6 & 2 & $2.5 \mathrm{E}$ & 16.6 & -- & -- \\
\hline beta-Stigmastanol & $19466-47-8$ & 145 & 11.0 & 2 & $2.3 \mathrm{E}$ & 11.0 & -- & -- \\
\hline 3-beta-Coprostanol ${ }^{4}$ & $360-68-9$ & 145 & 10.3 & 2 & $1 \mathrm{E}$ & 10.3 & -- & -- \\
\hline beta-Sitosterol & $83-46-5$ & 145 & 7.6 & 2 & $2.3 \mathrm{E}$ & 7.6 & -- & -- \\
\hline 3-Methyl-1(H)-indole (skatole) & $83-34-1$ & 145 & 3.4 & 1 & $.064 \mathrm{E}$ & ND & -- & -- \\
\hline \multicolumn{9}{|c|}{ Refrigerants and propellants } \\
\hline $\begin{array}{l}\text { 1,1,2-Trichloro-1,2,2- } \\
\text { trifluoroethane } \\
(\mathrm{CFC}-113)\end{array}$ & $76-13-1$ & 147 & ND & 0.038 & ND & ND & HBSL & 200,000 \\
\hline $\begin{array}{l}\text { Dichlorodifluoromethane } \\
\text { (CFC-12) }\end{array}$ & $75-71-8$ & 147 & ND & .18 & ND & ND & HBSL & 1,000 \\
\hline $\begin{array}{l}\text { Trichlorofluoromethane } \\
\qquad(\mathrm{CFC}-11)\end{array}$ & $75-69-4$ & 147 & ND & .08 & ND & ND & HBSL & 2,000 \\
\hline \multicolumn{9}{|c|}{ Solvents } \\
\hline$p$-Cresol & $106-44-5$ & 145 & 20.0 & 1 & $0.39 \mathrm{E}$ & 2.8 & -- & -- \\
\hline Perchloroethene (PCE) & $127-18-4$ & 147 & 17.0 & .03 & .16 & 2.7 & MCL & 5 \\
\hline cis-1,2-Dichloroethene & $156-59-2$ & 147 & 11.6 & .024 & .54 & 4.8 & MCL & 70 \\
\hline Trichloroethene (TCE) & $79-01-6$ & 147 & 6.8 & .038 & $.066 \mathrm{E}$ & ND & MCL & 5 \\
\hline $\begin{array}{l}\text { Methylene chloride (dichlo- } \\
\text { romethane) }{ }^{4}\end{array}$ & $75-09-2$ & 147 & 5.4 & .06 & $.083 \mathrm{E}$ & ND & MCL & 5 \\
\hline
\end{tabular}

romethane $)^{4}$ 
Appendix 1. Summary statistics and human-health benchmarks for anthropogenic organic compounds analyzed in source-water samples collected during the first phase of sampling, October 2002-March 2004. - Continued

[Compounds within each primary-use category are listed in order from highest to lowest detection frequency; CASRN, Chemical Abstracts Service Registry Number; E, estimated; AHTN, acetyl hexamethyl tetrahydronaphthalene; HHCB, hexahydrohexamethylcyclopentabenzopyran; MCPA, 2-methyl-4-chlorophenoxyacetic acid; MCL, Maximum Contaminant Level; HBSL, Health-Based Screening Level; ND, not detected; $\mu \mathrm{g} / \mathrm{L}$, micrograms per liter; --, no data; R, removed from data set; $\mathrm{C}$, censored]

\begin{tabular}{|c|c|c|c|c|c|c|c|c|}
\hline $\begin{array}{c}\text { Compound } \\
\text { (other name or abbreviation) }\end{array}$ & CASRN $^{1}$ & $\begin{array}{l}\text { Number } \\
\text { of } \\
\text { samples }\end{array}$ & $\begin{array}{l}\text { Detection } \\
\text { frequency } \\
\text { (percent) }\end{array}$ & $\begin{array}{c}\text { Laboratory } \\
\text { reporting level } \\
(\mu \mathrm{g} / \mathrm{L})\end{array}$ & $\begin{array}{c}\text { Maximum } \\
\text { detected } \\
\text { concentration } \\
(\mu \mathrm{g} / \mathrm{L})\end{array}$ & $\begin{array}{c}\text { Detection } \\
\text { frequency at } \\
0.1 \mu \mathrm{g} / \mathrm{L} \text { assess- } \\
\text { ment level }\end{array}$ & $\begin{array}{c}\text { Type of } \\
\text { human-health } \\
\text { benchmark }^{2}\end{array}$ & $\begin{array}{l}\text { Human-health } \\
\text { benchmark } \\
(\mu \mathrm{g} / \mathrm{L})\end{array}$ \\
\hline \multicolumn{9}{|c|}{ Refrigerants and propellants-Continued } \\
\hline$n$-Propylbenzene & $103-65-1$ & 147 & 4.8 & 0.042 & $0.08 \mathrm{E}$ & ND & -- & -- \\
\hline Acetone & $67-64-1$ & 147 & 1 & 6 & $3.8 \mathrm{E}$ & 1 & HBSL & 6,000 \\
\hline 1,3-Dichlorobenzene & $541-73-1$ & 147 & .7 & .03 & $.053 \mathrm{E}$ & ND & HBSL & 600 \\
\hline $\begin{array}{l}\text { Carbon tetrachloride (tetra- } \\
\text { chloromethane) }\end{array}$ & $56-23-5$ & 147 & .7 & .06 & $.043 \mathrm{E}$ & ND & MCL & 5 \\
\hline Tetrahydrofuran & 109-99-9 & 147 & .7 & 1.2 & $.32 \mathrm{E}$ & .7 & -- & -- \\
\hline 1,1,1,2-Tetrachloroethane & $630-20-6$ & 147 & ND & .03 & ND & ND & HBSL & 70 \\
\hline 1,1,1-Trichloroethane & $71-55-6$ & 147 & ND & .032 & ND & ND & MCL & 200 \\
\hline 1,1,2,2-Tetrachloroethane $\mathrm{e}^{5}$ & $79-34-5$ & 147 & ND & .03 & ND & ND & HBSL & .3 \\
\hline 1,1,2-Trichloroethane & $79-00-5$ & 147 & ND & .04 & ND & ND & MCL & 5 \\
\hline 1,1-Dichloroethane & $75-34-3$ & 147 & ND & .035 & ND & ND & -- & -- \\
\hline 1,1-Dichloroethene ${ }^{5}$ & $75-35-4$ & 147 & ND & .024 & ND & ND & MCL & 7 \\
\hline 1,2,4-Trichlorobenzene & $120-82-1$ & 147 & ND & .12 & ND & ND & MCL & 70 \\
\hline 1,2-Dichlorobenzene & $95-50-1$ & 147 & ND & .048 & ND & ND & MCL & 600 \\
\hline 1,2-Dichloroethane & $107-06-2$ & 147 & ND & .13 & ND & ND & MCL & 5 \\
\hline 2-Chlorotoluene & $95-49-8$ & 147 & ND & .04 & ND & ND & HBSL & 100 \\
\hline 2-Hexanone & $591-78-6$ & 147 & ND & .4 & ND & ND & -- & -- \\
\hline 4-Chlorotoluene & $106-43-4$ & 147 & ND & .05 & ND & ND & HBSL & 100 \\
\hline Bromobenzene $^{5}$ & $108-86-1$ & 147 & ND & .028 & ND & ND & -- & -- \\
\hline Chlorobenzene & $108-90-7$ & 147 & ND & .028 & ND & ND & MCL & 100 \\
\hline Chloroethane & $75-00-3$ & 147 & ND & .12 & ND & ND & -- & -- \\
\hline Dibromomethane & $74-95-3$ & 147 & ND & .05 & ND & ND & -- & -- \\
\hline $\begin{array}{l}\text { Diethyl ether } \\
\text { (1,1'-oxybisethane) }\end{array}$ & $60-29-7$ & 147 & ND & .08 & ND & ND & HBSL & 1,000 \\
\hline Hexachloroethane & $67-72-1$ & 147 & ND & .14 & ND & ND & HBSL & .7 \\
\hline Isophorone & $78-59-1$ & 145 & $\mathrm{R}$ & .5 & -- & -- & HBSL & 100 \\
\hline Methyl acetate & $79-20-9$ & 147 & ND & .43 & ND & ND & -- & -- \\
\hline
\end{tabular}


Appendix 1. Summary statistics and human-health benchmarks for anthropogenic organic compounds analyzed in source-water samples collected during the first phase of sampling, October 2002-March 2004. - Continued

[Compounds within each primary-use category are listed in order from highest to lowest detection frequency; CASRN, Chemical Abstracts Service Registry Number; E, estimated; AHTN, acetyl hexamethyl tetrahydronaphthalene; HHCB, hexahydrohexamethylcyclopentabenzopyran; MCPA, 2-methyl-4-chlorophenoxyacetic acid; MCL, Maximum Contaminant Level; HBSL, Health-Based Screening Level; ND, not detected; $\mu \mathrm{g} / \mathrm{L}$, micrograms per liter; --, no data; R, removed from data set; $\mathrm{C}$, censored]

\begin{tabular}{|c|c|c|c|c|c|c|c|c|}
\hline $\begin{array}{c}\text { Compound } \\
\text { (other name or abbreviation) }\end{array}$ & CASRN ${ }^{1}$ & $\begin{array}{l}\text { Number } \\
\text { of } \\
\text { samples }\end{array}$ & $\begin{array}{l}\text { Detection } \\
\text { frequency } \\
\text { (percent) }\end{array}$ & $\begin{array}{c}\text { Laboratory } \\
\text { reporting level } \\
(\mu \mathrm{g} / \mathrm{L})\end{array}$ & $\begin{array}{c}\text { Maximum } \\
\text { detected } \\
\text { concentration } \\
(\mu \mathrm{g} / \mathrm{L})\end{array}$ & $\begin{array}{c}\text { Detection } \\
\text { frequency at } \\
0.1 \mu \mathrm{g} / \mathrm{L} \text { assess- } \\
\text { ment level }\end{array}$ & $\begin{array}{c}\text { Type of } \\
\text { human-health } \\
\text { benchmark }^{2}\end{array}$ & $\begin{array}{c}\text { Human-health } \\
\text { benchmark } \\
(\mu \mathrm{g} / \mathrm{L})\end{array}$ \\
\hline \multicolumn{9}{|c|}{ Refrigerants and propellants-Continued } \\
\hline Methyl ethyl ketone (MEK) & $78-93-3$ & 147 & ND & 2 & ND & ND & HBSL & 4,000 \\
\hline $\begin{array}{l}\text { Methyl isobutyl ketone } \\
\text { (4-methyl-2-pentanone; } \\
\text { MIBK) }\end{array}$ & $108-10-1$ & 147 & ND & .37 & ND & ND & -- & -- \\
\hline trans-1,2-Dichloroethene & $156-60-5$ & 147 & ND & .032 & ND & ND & MCL & 100 \\
\hline
\end{tabular}

${ }^{1}$ This report contains CAS Registry Numbers ${ }^{\circledR}$, which is a Registered Trademark of the American Chemical Society. The CAS recommends the verification of the CASRNs through CAS Client Services ${ }^{\text {SM }}$. ${ }^{2}$ HBSL values shown for carcinogens represent the low end $\left(10^{-6}\right)$ of the HBSL range (10 $10^{-6}$ to $10^{-4}$ cancer risk level) (Toccalino, Norman, and others, 2006).

${ }^{3}$ The U.S. Environmental Protection Agency MCL of $80 \mu \mathrm{g} / \mathrm{L}$ is for the sum of the concentrations of four trihalomethanes.

${ }^{4}$ Compound detected in less than 5 percent of field blanks.

${ }^{5}$ Compound on U.S. Environmental Protection Agency's Contaminant Candidate List 2 (U.S. Environmental Protection Agency, 2005).

${ }^{6}$ The sum of concentrations from cis-1,3- and trans-1,3-dichloropropene may be compared to the HBSL range (0.3-30 $\left.\mu \mathrm{g} / \mathrm{L}\right)$ for the mixed isomer of 1,3-dichloropropene, CASRN 542756.

${ }^{7}$ The concentrations from $m$-/ $p$ - and $o$-xylene can be compared to the MCL $(10,000 \mu \mathrm{g} / \mathrm{L})$ for mixed xylenes, CASRN 1330207.

${ }^{8}$ Additional herbicides and herbicide degradates only sampled at the Neuse, Potomac, and White Rivers during the first sampling phase.

${ }^{9}$ U.S. Environmental Protection Agency Office of Water recommends that the concentration of any combination of two or more of the three aldicarb compounds should not be greater than $7 \mu \mathrm{g} / \mathrm{L}$ because of similar mode of action.

${ }^{10}$ Concentrations of cis-permethrin may be compared to the HBSL range $(4-400 \mu \mathrm{g} / \mathrm{L})$ for permethrin, CASRN 52645531. 
Appendix 2. Summary statistics and human-health benchmarks for anthropogenic organic compounds detected in source- and finished-water samples collected during the second phase of sampling, June 2004-August 2005.

[Compounds within each primary-use category are listed in order from highest to lowest source-water detection frequency. Human-health benchmarks in bold are Maximum Contaminant Levels. CASRM, Chemical Abstracts Service Registry Number; E, estimated; AHTN, acetyl hexamethyl tetrahydronaphthalene; HHCB, hexahydrohexamethylcyclopentabenzopyran; MCPA, 2-methyl-4-chlorophenoxyacetic acid; $\mu \mathrm{g} / \mathrm{L}$, micrograms per liter; SW, source water; FW, finished water; $\mathrm{BQ}$, benchmark quotient; <, less than; >, greater than; ND, not detected; --, none]

\begin{tabular}{|c|c|c|c|c|c|c|c|c|c|}
\hline \multirow[t]{2}{*}{ Compound } & \multirow[t]{2}{*}{ CASRN $^{1}$} & \multirow[t]{2}{*}{$\begin{array}{l}\text { Number of } \\
\text { samples } \\
\text { SW/FW }\end{array}$} & \multicolumn{2}{|c|}{$\begin{array}{l}\text { Detection frequency } \\
\text { (percent) }\end{array}$} & \multicolumn{2}{|c|}{$\begin{array}{l}\text { Maximum concentration } \\
(\mu \mathrm{g} / \mathrm{L})\end{array}$} & \multirow[t]{2}{*}{$\begin{array}{l}\text { Human-health } \\
\text { benchmark }^{2}\end{array}$} & \multicolumn{2}{|c|}{$\begin{aligned} \text { Number of concentrations with } \\
\text { B0 }>0.1 \text {; } \\
\text { (1) number of concentrations with } \\
\text { BO }>1\end{aligned}$} \\
\hline & & & Source water & Finished water & Source water & Finished water & & Source water & Finished water \\
\hline \multicolumn{10}{|c|}{ Disinfection by-products } \\
\hline Chloroform $^{3}$ & $67-66-3$ & $95 / 94$ & 72 & 100 & 1.5 & 65.6 & 80 & -- & 78 \\
\hline Bromodichloromethane ${ }^{3}$ & $75-27-4$ & $95 / 94$ & 8.4 & 100 & .16 & 24.0 & 80 & -- & 35 \\
\hline Bromoform $^{3}$ & $75-25-2$ & $95 / 94$ & ND & 32 & ND & 1.07 & 80 & -- & -- \\
\hline Dibromochloromethane ${ }^{3}$ & $124-48-1$ & $95 / 94$ & ND & 98 & 1.8 & 10.6 & 80 & -- & 2 \\
\hline Trihalomethanes & -- & $95 / 94$ & 72 & 100 & 1.8 & 86 & 80 & -- & $90(1)$ \\
\hline \multicolumn{10}{|c|}{ Fumigant-related compounds } \\
\hline 1,4-Dichlorobenzene ${ }^{3}$ & $106-46-7$ & $95 / 94$ & ND & 3.2 & ND & $0.05 \mathrm{E}$ & 75 & -- & -- \\
\hline \multicolumn{10}{|c|}{ Fungicides } \\
\hline Benomyl & $17804-35-2$ & $90 / 89$ & 10.0 & 4.5 & 0.14 & $0.008 \mathrm{E}$ & 40 & -- & -- \\
\hline Myclobutanil & 88671-89-0 & $90 / 87$ & 5.6 & 5.7 & .018 & .018 & 200 & -- & -- \\
\hline Metalaxyl & $57837-19-1$ & $90 / 87$ & 4.4 & ND & .025 & ND & 600 & -- & -- \\
\hline Iprodione & $36734-19-7$ & $90 / 87$ & 2.2 & 1.1 & $.029 \mathrm{E}$ & $.018 \mathrm{E}$ & .8 & -- & -- \\
\hline Pentachlorophenol & $87-86-5$ & $77 / 75$ & 1.0 & ND & $.12 \mathrm{E}$ & ND & 1 & 1 & -- \\
\hline Chlorothalonil & $1897-45-6$ & $84 / 82$ & ND & 1.2 & ND & .71 & 5 & -- & 1 \\
\hline \multicolumn{10}{|c|}{ Gasoline hydrocarbons, oxygenates, and oxygenate degradates } \\
\hline $\begin{array}{l}\text { Methyl tert-butyl ether } \\
\quad(\mathrm{MTBE})^{4}\end{array}$ & $1634-04-4$ & $95 / 94$ & 36 & 32 & 0.85 & 0.56 & -- & -- & -- \\
\hline Benzene & $71-43-2$ & $83 / 81$ & 14 & 25 & $.095 \mathrm{E}$ & $.028 \mathrm{E}$ & 5 & -- & -- \\
\hline$m$ - and $p$-Xylene ${ }^{5}$ & $\begin{array}{l}106-42-3 \\
108-38-3\end{array}$ & $95 / 94$ & 13 & 33 & .27 & 8.7 & 10,000 & -- & -- \\
\hline Toluene & $108-88-3$ & $81 / 80$ & 12 & 9.9 & .49 & .25 & 1,000 & -- & -- \\
\hline 1,2,4-Trimethylbenzene & $95-63-6$ & $95 / 94$ & 9.5 & 3.2 & .13 & $.055 \mathrm{E}$ & -- & -- & -- \\
\hline Ethylbenzene & $100-41-4$ & $95 / 94$ & 6.3 & 16 & $.069 \mathrm{E}$ & 2.1 & 700 & -- & -- \\
\hline$o$-Xylene ${ }^{5}$ & $95-47-6$ & $95 / 94$ & 5.3 & 15 & .11 & 7.4 & 10,000 & -- & -- \\
\hline $\begin{array}{l}\text { tert-Amyl methyl ether } \\
\text { (TAME) }\end{array}$ & $994-05-8$ & $95 / 94$ & 4.2 & 1.1 & $.045 \mathrm{E}$ & $.034 \mathrm{E}$ & -- & -- & -- \\
\hline
\end{tabular}


Appendix 2. Summary statistics and human-health benchmarks for anthropogenic organic compounds detected in source- and finished-water samples collected during the second phase of sampling, June 2004-August 2005. - Continued

[Compounds within each primary-use category are listed in order from highest to lowest source-water detection frequency. Human-health benchmarks in bold are Maximum Contaminant Levels. CASRM, Chemical Abstracts Service Registry Number; E, estimated; AHTN, acetyl hexamethyl tetrahydronaphthalene; HHCB, hexahydrohexamethylcyclopentabenzopyran; MCPA, 2-methyl-4-chlorophenoxyacetic acid; $\mu \mathrm{g} / \mathrm{L}$, micrograms per liter; SW, source water; FW, finished water; BQ, benchmark quotient; <, less than; >, greater than; ND, not detected; --, none]

\begin{tabular}{|c|c|c|c|c|c|c|c|c|c|}
\hline \multirow[t]{2}{*}{ Compound } & \multirow[t]{2}{*}{ CASRN ${ }^{1}$} & \multirow[t]{2}{*}{$\begin{array}{c}\text { Number of } \\
\text { samples } \\
\text { SW/FW }\end{array}$} & \multicolumn{2}{|c|}{$\begin{array}{l}\text { Detection frequency } \\
\text { (percent) }\end{array}$} & \multicolumn{2}{|c|}{$\begin{array}{l}\text { Maximum concentration } \\
(\mu \mathrm{g} / \mathrm{L})\end{array}$} & \multirow[t]{2}{*}{$\begin{array}{c}\text { Human-health } \\
\text { benchmark }^{2}\end{array}$} & \multicolumn{2}{|c|}{$\begin{array}{l}\text { Number of concentrations with } \\
\text { BQ }>0.1 \text {; } \\
\text { (1) number of concentrations with } \\
B 0>1\end{array}$} \\
\hline & & & Source water & Finished water & Source water & Finished water & & Source water & Finished water \\
\hline \multicolumn{10}{|c|}{ Gasoline hydrocarbons, oxygenates, and oxygenate degradates-Continued } \\
\hline 1,3,5-Trimethylbenzene & $108-67-8$ & $95 / 94$ & 3.2 & ND & $0.041 \mathrm{E}$ & ND & -- & -- & -- \\
\hline $\begin{array}{l}\text { 1-Ethyl-2-methylben- } \\
\text { zene } \\
\text { (o-Ethyl toluene) }\end{array}$ & $611-14-3$ & $95 / 94$ & 3.2 & ND & $.031 \mathrm{E}$ & ND & -- & -- & -- \\
\hline 1-Methylnaphthalene & $90-12-0$ & $96 / 96$ & 3.1 & 2.1 & $.013 \mathrm{E}$ & $0.017 \mathrm{E}$ & -- & -- & -- \\
\hline 2-Methylnaphthalene ${ }^{4}$ & $91-57-6$ & $96 / 96$ & 3.1 & 4.2 & $.019 \mathrm{E}$ & $.034 \mathrm{E}$ & 30 & -- & -- \\
\hline Styrene & $100-42-5$ & $95 / 94$ & 2.1 & 3.2 & $.027 \mathrm{E}$ & $.023 \mathrm{E}$ & 100 & -- & -- \\
\hline $\begin{array}{l}\text { Ethyl tert-butyl ether } \\
\text { (ETBE) }\end{array}$ & $637-92-3$ & $95 / 94$ & 1.1 & 1.1 & $.020 \mathrm{E}$ & $.023 \mathrm{E}$ & -- & -- & -- \\
\hline$p$-Isopropyltoluene & $99-87-6$ & $95 / 94$ & 1.1 & ND & $.010 \mathrm{E}$ & ND & -- & -- & -- \\
\hline $\begin{array}{l}\text { 1,2,3,4-Tetramethylben- } \\
\text { zene }\end{array}$ & $488-23-3$ & $95 / 94$ & ND & 2.1 & ND & $.062 \mathrm{E}$ & -- & -- & -- \\
\hline $\begin{array}{l}\text { 1,2,3,5-Tetramethylben- } \\
\text { zene }\end{array}$ & $527-53-7$ & $95 / 94$ & ND & 7.4 & ND & .15 & -- & -- & -- \\
\hline 1,2,3-Trimethylbenzene & $526-73-8$ & $95 / 94$ & ND & 4.3 & ND & .06 & -- & -- & -- \\
\hline Isopropylbenzene & $98-82-8$ & $95 / 94$ & ND & 6.4 & ND & $.036 \mathrm{E}$ & 700 & -- & -- \\
\hline$n$-Butylbenzene & $104-51-8$ & $95 / 94$ & ND & 1.1 & ND & $.013 \mathrm{E}$ & -- & -- & -- \\
\hline Naphthalene & $91-20-3$ & $95 / 94$ & ND & 2.1 & ND & $.36 \mathrm{E}$ & 100 & -- & -- \\
\hline \multicolumn{10}{|c|}{ Herbicides and herbicide degradates } \\
\hline Atrazine & 1912-24-9 & $90 / 87$ & 82 & 87 & 5.0 & 3.4 & 3 & $22(2)$ & $21(1)$ \\
\hline Simazine & $122-34-9$ & $90 / 87$ & 82 & 89 & .74 & .73 & 4 & 4 & 6 \\
\hline $\begin{array}{l}\text { Metolachlor oxanilic } \\
\text { acid }^{6}\end{array}$ & -- & $49 / 48$ & 77 & 59 & .63 & .46 & -- & -- & -- \\
\hline $\begin{array}{l}\text { Metolachlor ethane } \\
\text { sulfonic acid }\end{array}$ & -- & $49 / 48$ & 68 & 59 & 2.0 & 1.9 & -- & -- & -- \\
\hline $\begin{array}{l}\text { Alachlor ethane sulfonic } \\
\text { acid }^{6}\end{array}$ & -- & $49 / 48$ & 61 & 59 & .27 & .37 & -- & -- & -- \\
\hline
\end{tabular}


Appendix 2. Summary statistics and human-health benchmarks for anthropogenic organic compounds detected in source- and finished-water samples collected during the second phase of sampling, June 2004-August 2005. - Continued

[Compounds within each primary-use category are listed in order from highest to lowest source-water detection frequency. Human-health benchmarks in bold are Maximum Contaminant Levels. CASRM, Chemical Abstracts Service Registry Number; E, estimated; AHTN, acetyl hexamethyl tetrahydronaphthalene; HHCB, hexahydrohexamethylcyclopentabenzopyran; MCPA, 2-methyl-4-chlorophenoxyacetic acid; $\mu \mathrm{g} / \mathrm{L}$, micrograms per liter; SW, source water; FW, finished water; $\mathrm{BQ}$, benchmark quotient; <, less than; >, greater than; ND, not detected; --, none]

\begin{tabular}{|c|c|c|c|c|c|c|c|c|c|}
\hline \multirow[t]{2}{*}{ Compound } & \multirow[t]{2}{*}{ CASRN ${ }^{1}$} & \multirow[t]{2}{*}{$\begin{array}{l}\text { Number of } \\
\text { samples } \\
\text { SW/FW }\end{array}$} & \multicolumn{2}{|c|}{$\begin{array}{l}\text { Detection frequency } \\
\text { (percent) }\end{array}$} & \multicolumn{2}{|c|}{$\begin{array}{l}\text { Maximum concentration } \\
(\mu \mathrm{g} / \mathrm{L})\end{array}$} & \multirow[t]{2}{*}{$\begin{array}{l}\text { Human-health } \\
\text { benchmark }^{2}\end{array}$} & \multicolumn{2}{|c|}{$\begin{aligned} \text { Number of concentrations with } \\
\text { BO }>0.1 \text {; } \\
\text { (1) number of concentrations with } \\
\text { BO }>1\end{aligned}$} \\
\hline & & & Source water & Finished water & Source water & Finished water & & Source water & Finished water \\
\hline \multicolumn{10}{|c|}{ Herbicides and herbicide degradates - Continued } \\
\hline Metolachlor & $51218-45-2$ & $90 / 87$ & 59 & 54 & 0.80 & 0.47 & 700 & -- & -- \\
\hline Deethylatrazine (DEA) & $6190-65-4$ & $90 / 87$ & 58 & 68 & .13 & .13 & -- & -- & -- \\
\hline $\begin{array}{l}\text { Deisopropylatrazine } \\
\text { (DIA) }\end{array}$ & $1007-28-9$ & $90 / 89$ & 58 & 63 & .090 & .12 & -- & -- & -- \\
\hline Prometon & $1610-18-0$ & $90 / 87$ & 56 & 25 & .19 & .20 & 400 & -- & -- \\
\hline 2-Hydroxyatrazine & $2163-68-0$ & $89 / 88$ & 52 & 51 & $.38 \mathrm{E}$ & $.30 \mathrm{E}$ & 70 & -- & -- \\
\hline Alachlor oxanilic acid & -- & $49 / 48$ & 50 & 50 & .26 & .12 & -- & -- & -- \\
\hline 3,4-Dichloroaniline & $95-76-1$ & $85 / 83$ & 47 & 2.4 & .083 & .009 & -- & -- & -- \\
\hline $2,4-\mathrm{D}$ & $94-75-7$ & $90 / 89$ & 44 & 52 & .76 & .46 & 70 & -- & -- \\
\hline Diuron & $330-54-1$ & $90 / 89$ & 42 & 24 & .22 & .18 & 2 & 1 & -- \\
\hline $\begin{array}{l}\text { Acetochlor oxanilic } \\
\text { acid }^{6}\end{array}$ & -- & $49 / 48$ & 32 & 25 & .65 & .40 & -- & -- & -- \\
\hline $\begin{array}{l}\text { Acetochlor/metolachlor } \\
\text { ethane sulfonic acid } \\
\text { 2nd amide }\end{array}$ & -- & $49 / 48$ & 27 & 27 & .10 & .08 & -- & -- & -- \\
\hline $\begin{array}{l}\text { Acetochlor ethane sulfo- } \\
\text { nic acid }{ }^{6}\end{array}$ & -- & $49 / 48$ & 25 & 27 & .40 & .31 & -- & -- & -- \\
\hline Bentazon & $25057-89-0$ & $90 / 87$ & 18 & 16 & $.020 \mathrm{E}$ & $.020 \mathrm{E}$ & 200 & -- & -- \\
\hline Acetochlor & $34256-82-1$ & $90 / 87$ & 16 & 11 & .24 & .14 & 1 & 1 & 1 \\
\hline Terbuthylazine & $5915-41-3$ & $90 / 87$ & 16 & 13 & .028 & .027 & 2 & -- & -- \\
\hline MCPA & $94-74-6$ & $90 / 87$ & 15 & 15 & .44 & .39 & 30 & -- & -- \\
\hline Alachlor & $15972-60-8$ & $90 / 87$ & 13 & 10 & .022 & .017 & 2 & -- & -- \\
\hline $\begin{array}{l}\text { Deethyldeisopropyl } \\
\text { atrazine }\end{array}$ & $3397-62-4$ & $90 / 89$ & 7.7 & 7.8 & $.11 \mathrm{E}$ & $.071 \mathrm{E}$ & -- & -- & -- \\
\hline Triclopyr & $55335-06-3$ & $90 / 89$ & 11 & 9.0 & .45 & .35 & 400 & -- & -- \\
\hline $\begin{array}{l}\text { Acetochlor sulfynila- } \\
\text { cetic acid }{ }^{6}\end{array}$ & -- & $49 / 48$ & 9.1 & 11 & .28 & .17 & -- & -- & -- \\
\hline
\end{tabular}


Appendix 2. Summary statistics and human-health benchmarks for anthropogenic organic compounds detected in source- and finished-water samples collected during the second phase of sampling, June 2004-August 2005. - Continued

[Compounds within each primary-use category are listed in order from highest to lowest source-water detection frequency. Human-health benchmarks in bold are Maximum Contaminant Levels. CASRM, Chemical Abstracts Service Registry Number; E, estimated; AHTN, acetyl hexamethyl tetrahydronaphthalene; HHCB, hexahydrohexamethylcyclopentabenzopyran; MCPA, 2-methyl-4-chlorophenoxyacetic acid; $\mu \mathrm{g} / \mathrm{L}$, micrograms per liter; SW, source water; FW, finished water; BQ, benchmark quotient; <, less than; >, greater than; ND, not detected; --, none]

\begin{tabular}{|c|c|c|c|c|c|c|c|c|c|}
\hline \multirow[t]{2}{*}{ Compound } & \multirow[t]{2}{*}{ CASRN' } & \multirow[t]{2}{*}{$\begin{array}{l}\text { Number of } \\
\text { samples } \\
\text { SW/FW }\end{array}$} & \multicolumn{2}{|c|}{$\begin{array}{l}\text { Detection frequency } \\
\text { (percent) }\end{array}$} & \multicolumn{2}{|c|}{$\begin{array}{l}\text { Maximum concentration } \\
\qquad(\mu \mathrm{g} / \mathrm{L})\end{array}$} & \multirow[t]{2}{*}{$\begin{array}{l}\text { Human-health } \\
\text { benchmark }^{2}\end{array}$} & \multicolumn{2}{|c|}{$\begin{aligned} \text { Number of concentrations with } \\
\text { B0 }>0.1 \text {; } \\
\text { (1) number of concentrations with } \\
\text { BO }>1\end{aligned}$} \\
\hline & & & Source water & Finished water & Source water & Finished water & & Source water & Finished water \\
\hline \multicolumn{10}{|c|}{ Herbicides and herbicide degradates - Continued } \\
\hline $\begin{array}{l}\text { Alachlor ethane sulfonic } \\
\text { acid } 2 \text { nd amide }\end{array}$ & -- & $49 / 48$ & 9.1 & 4.5 & 0.06 & 0.070 & -- & -- & -- \\
\hline Pendimethalin & $40487-42-1$ & $90 / 87$ & 7.8 & 4.6 & .056 & .025 & 70 & -- & -- \\
\hline Dimethenamid $^{6}$ & $87674-68-8$ & $49 / 48$ & 6.8 & 2.3 & .89 & .120 & -- & -- & -- \\
\hline $\begin{array}{l}\text { Dimethenamid ethane } \\
\text { sulfonic acid }\end{array}$ & -- & $49 / 48$ & 6.8 & ND & .03 & ND & -- & -- & -- \\
\hline $\begin{array}{l}\text { 4-Chloro-2-methylphe- } \\
\text { nol }\end{array}$ & $1570-64-5$ & $90 / 87$ & 6.7 & ND & $.008 \mathrm{E}$ & ND & -- & -- & -- \\
\hline Imazaquin & $81335-37-7$ & $90 / 89$ & 6.7 & 5.6 & $.028 \mathrm{E}$ & $.025 \mathrm{E}$ & 2,000 & -- & -- \\
\hline Tebuthiuron & $34014-18-1$ & $90 / 87$ & 6.7 & 5.7 & .031 & $.023 \mathrm{E}$ & 1,000 & -- & -- \\
\hline Trifluralin & $1582-09-8$ & $90 / 87$ & 6.7 & 2.3 & .009 & $.006 \mathrm{E}$ & 20 & -- & -- \\
\hline Dacthal & $1861-32-1$ & $90 / 87$ & 5.6 & 6.9 & .005 & .005 & 70 & -- & -- \\
\hline Siduron & $1982-49-6$ & & 5.6 & ND & $.011 \mathrm{E}$ & ND & -- & -- & -- \\
\hline $\begin{array}{l}\text { Alachlor sulfynilacetic } \\
\text { acid }\end{array}$ & $\begin{array}{l}140939- \\
16-8\end{array}$ & $49 / 48$ & 4.5 & 2.3 & .06 & .050 & -- & -- & -- \\
\hline 2,4-D methyl ester & $1928-38-7$ & $90 / 87$ & 4.4 & 2.3 & .078 & .063 & -- & -- & -- \\
\hline Imazethapyr & $81335-77-5$ & $90 / 89$ & 4.4 & 1.1 & .20 & $.026 \mathrm{E}$ & 2,000 & -- & -- \\
\hline Metsulfuron methyl ${ }^{4}$ & $74223-64-6$ & $90 / 89$ & 4.4 & 2.2 & $.077 \mathrm{E}$ & $.058 \mathrm{E}$ & 2,000 & -- & -- \\
\hline Chlorimuron-ethyl & $90982-32-4$ & $90 / 89$ & 3.3 & 1.1 & $.015 \mathrm{E}$ & $.006 \mathrm{E}$ & 600 & -- & -- \\
\hline Flumetsulam & $98967-40-9$ & $90 / 88$ & 3.3 & 1.1 & $.028 \mathrm{E}$ & .049 & 7,000 & -- & -- \\
\hline Hexazinone & $51235-04-2$ & $90 / 87$ & 3.3 & 4.6 & .022 & .021 & 400 & -- & -- \\
\hline Metribuzin & 21087-64-9 & $90 / 87$ & 3.3 & 1.1 & .056 & .016 & 90 & -- & -- \\
\hline Sulfometuron-methyl & $74222-97-2$ & $90 / 89$ & 3.3 & ND & $.009 \mathrm{E}$ & ND & -- & -- & -- \\
\hline $\begin{array}{l}\text { Flufenacet ethane sulfo- } \\
\text { nic } \text { acid }^{6}\end{array}$ & -- & $49 / 48$ & 2.3 & 2.3 & .10 & .090 & -- & -- & -- \\
\hline 2,6-Diethylaniline & $579-66-8$ & $90 / 87$ & 1.1 & 1.1 & $.002 \mathrm{E}$ & $.003 \mathrm{E}$ & -- & -- & -- \\
\hline
\end{tabular}


Appendix 2. Summary statistics and human-health benchmarks for anthropogenic organic compounds detected in source- and finished-water samples collected during the second phase of sampling, June 2004-August 2005. —Continued

[Compounds within each primary-use category are listed in order from highest to lowest source-water detection frequency. Human-health benchmarks in bold are Maximum Contaminant Levels. CASRM, Chemical Abstracts Service Registry Number; E, estimated; AHTN, acetyl hexamethyl tetrahydronaphthalene; HHCB, hexahydrohexamethylcyclopentabenzopyran; MCPA, 2-methyl-4-chlorophenoxyacetic acid; $\mu \mathrm{g} / \mathrm{L}$, micrograms per liter; SW, source water; FW, finished water; $\mathrm{BQ}$, benchmark quotient; <, less than; >, greater than; ND, not detected; --, none]

\begin{tabular}{|c|c|c|c|c|c|c|c|c|c|}
\hline \multirow[t]{2}{*}{ Compound } & \multirow[t]{2}{*}{ CASRN $^{1}$} & \multirow[t]{2}{*}{$\begin{array}{l}\text { Number of } \\
\text { samples } \\
\text { SW/FW }\end{array}$} & \multicolumn{2}{|c|}{$\begin{array}{l}\text { Detection frequency } \\
\text { (percent) }\end{array}$} & \multicolumn{2}{|c|}{$\begin{array}{l}\text { Maximum concentration } \\
(\mu \mathrm{g} / \mathrm{L})\end{array}$} & \multirow[t]{2}{*}{$\begin{array}{l}\text { Human-health } \\
\text { benchmark }^{2}\end{array}$} & \multicolumn{2}{|c|}{$\begin{aligned} \text { Number of concentrations with } \\
\text { BO }>0.1 \text {; } \\
\text { (1) number of concentrations with } \\
\text { BO }>1\end{aligned}$} \\
\hline & & & Source water & Finished water & Source water & Finished water & & Source water & Finished water \\
\hline \multicolumn{10}{|c|}{ Herbicides and herbicide degradates-Continued } \\
\hline Bensulfuron-methyl & $83055-99-6$ & $90 / 89$ & 1.1 & ND & $0.008 \mathrm{E}$ & ND & 1,000 & -- & -- \\
\hline Bromacil & $314-40-9$ & $90 / 87$ & 1.1 & ND & $.017 \mathrm{E}$ & ND & 70 & -- & -- \\
\hline Prometryn & $101-42-8$ & $90 / 87$ & 1.1 & ND & $.005 \mathrm{E}$ & ND & 300 & -- & -- \\
\hline Propyzamide & $7287-19-6$ & $90 / 87$ & 1.1 & 3.4 & $.006 \mathrm{E}$ & $0.007 \mathrm{E}$ & 1 & -- & -- \\
\hline Dicamba & $23950-58-5$ & $90 / 87$ & ND & 1.1 & ND & $.071 \mathrm{E}$ & 3,000 & -- & -- \\
\hline Dinoseb & $1918-00-9$ & $90 / 89$ & ND & 1.1 & ND & $.006 \mathrm{E}$ & 7 & -- & -- \\
\hline Diphenamid & $88-85-7$ & $90 / 89$ & ND & 1.1 & ND & .026 & 200 & -- & -- \\
\hline Fluometuron & $957-51-7$ & $90 / 89$ & ND & 3.4 & ND & $.007 \mathrm{E}$ & 4 & -- & -- \\
\hline \multicolumn{10}{|c|}{ Insecticides and insecticide degradates } \\
\hline Desulfinylfipronil & -- & $90 / 87$ & 42 & 24 & $0.010 \mathrm{E}$ & $0.008 \mathrm{E}$ & -- & -- & -- \\
\hline Fipronil & $\begin{array}{l}120068- \\
37-3\end{array}$ & $90 / 87$ & 39 & 1.1 & .038 & $.009 \mathrm{E}$ & -- & -- & -- \\
\hline Carbaryl & $63-25-2$ & $90 / 87$ & 20 & 8.0 & .25 & .035 & 40 & -- & -- \\
\hline Fipronil sulfide & $\begin{array}{l}120067- \\
83-6\end{array}$ & $90 / 87$ & 20 & 12 & $.010 \mathrm{E}$ & $.008 \mathrm{E}$ & -- & -- & -- \\
\hline Diazinon & $333-41-5$ & $90 / 87$ & 17 & 1.1 & .014 & .006 & 1 & -- & -- \\
\hline Fipronil sulfone & $\begin{array}{l}120068- \\
36-2\end{array}$ & $90 / 87$ & 13 & 1.1 & $.012 \mathrm{E}$ & $.007 \mathrm{E}$ & -- & -- & -- \\
\hline Desulfinylfipronil amide & -- & $90 / 87$ & 8.9 & 6.9 & $.013 \mathrm{E}$ & $.006 \mathrm{E}$ & -- & -- & -- \\
\hline 1-Naphthol & $90-15-3$ & $90 / 87$ & 6.7 & 1.1 & $.015 \mathrm{E}$ & $.013 \mathrm{E}$ & -- & -- & -- \\
\hline Chlorpyrifos & $2921-88-2$ & $90 / 87$ & 5.6 & ND & .006 & ND & 2 & -- & -- \\
\hline Propoxur & $114-26-1$ & $90 / 87$ & 5.6 & ND & $.005 \mathrm{E}$ & ND & -- & -- & -- \\
\hline 3-Ketocarbofuran & 16709-30-1 & $90 / 87$ & 1.1 & 1.1 & $.026 \mathrm{E}$ & $.02 \mathrm{E}$ & -- & -- & -- \\
\hline Imidacloprid & $\begin{array}{l}138261- \\
41-3\end{array}$ & $90 / 87$ & 4.4 & 1.1 & .042 & .021 & 400 & -- & -- \\
\hline Malathion & $121-75-5$ & $90 / 87$ & 2.2 & 1.1 & $.018 \mathrm{E}$ & $.009 \mathrm{E}$ & 50 & -- & -- \\
\hline
\end{tabular}


Appendix 2. Summary statistics and human-health benchmarks for anthropogenic organic compounds detected in source- and finished-water samples collected during the second phase of sampling, June 2004-August 2005. —Continued

[Compounds within each primary-use category are listed in order from highest to lowest source-water detection frequency. Human-health benchmarks in bold are Maximum Contaminant Levels. CASRM, Chemical Abstracts Service Registry Number; E, estimated; AHTN, acetyl hexamethyl tetrahydronaphthalene; HHCB, hexahydrohexamethylcyclopentabenzopyran; MCPA, 2-methyl-4-chlorophenoxyacetic acid; $\mu \mathrm{g} / \mathrm{L}$, micrograms per liter; SW, source water; FW, finished water; BQ, benchmark quotient; <, less than; >, greater than; ND, not detected; --, none]

\begin{tabular}{|c|c|c|c|c|c|c|c|c|c|}
\hline \multirow[t]{2}{*}{ Compound } & \multirow[t]{2}{*}{ CASRN $^{1}$} & \multirow[t]{2}{*}{$\begin{array}{l}\text { Number of } \\
\text { samples } \\
\text { SW/FW }\end{array}$} & \multicolumn{2}{|c|}{$\begin{array}{l}\text { Detection frequency } \\
\text { (percent) }\end{array}$} & \multicolumn{2}{|c|}{$\begin{array}{l}\text { Maximum concentration } \\
\qquad(\mu \mathrm{g} / \mathrm{L})\end{array}$} & \multirow[t]{2}{*}{$\begin{array}{l}\text { Human-health } \\
\text { benchmark }^{2}\end{array}$} & \multicolumn{2}{|c|}{$\begin{array}{l}\text { Number of concentrations with } \\
\text { B0 }>0.1 \text {; } \\
\text { (1) number of concentrations with } \\
\text { B0 }>1\end{array}$} \\
\hline & & & Source water & Finished water & Source water & Finished water & & Source water & Finished water \\
\hline \multicolumn{10}{|c|}{ Insecticides and insecticide degradates-Continued } \\
\hline Dieldrin & $60-57-1$ & $90 / 87$ & 1.1 & ND & 0.004 & ND & 0.002 & $1(1)$ & -- \\
\hline Bendiocarb & $22781-23-3$ & $90 / 87$ & ND & 1.1 & ND & $0.019 \mathrm{E}$ & 9 & -- & -- \\
\hline Diazinon, oxygen analog & $962-58-3$ & $90 / 87$ & ND & 1.1 & ND & .011 & -- & -- & -- \\
\hline Dichlorvos & $62-73-7$ & $90 / 87$ & ND & 1.1 & ND & $.005 \mathrm{E}$ & .4 & -- & -- \\
\hline Malaoxon & $1634-78-2$ & $90 / 87$ & ND & 1.1 & ND & $.010 \mathrm{E}$ & -- & -- & -- \\
\hline \multicolumn{10}{|c|}{ Manufacturing additives } \\
\hline $\begin{array}{l}\text { Tri(2-chloroethyl)phos- } \\
\text { phate }^{4}\end{array}$ & $115-96-8$ & $96 / 96$ & 33 & 31 & $0.26 \mathrm{E}$ & $0.22 \mathrm{E}$ & -- & -- & -- \\
\hline $\begin{array}{l}\text { Tris(dichlorisopropyl) } \\
\text { phosphate }\end{array}$ & $13674-87-8$ & $96 / 96$ & 29 & 28 & $.17 \mathrm{E}$ & 5.5 & -- & -- & -- \\
\hline Tributyl phosphate & $126-73-8$ & $71 / 72$ & 21 & 2.8 & $.12 \mathrm{E}$ & $.29 \mathrm{E}$ & -- & -- & -- \\
\hline $\begin{array}{l}\text { Tri(2-butoxyethyl) } \\
\text { phosphate }\end{array}$ & $78-51-3$ & $96 / 96$ & 16 & 11 & $.4 \mathrm{E}$ & .56 & -- & -- & -- \\
\hline Triphenyl phosphate & $115-86-6$ & $96 / 96$ & 15 & 8.3 & $.1 \mathrm{E}$ & $.16 \mathrm{E}$ & -- & -- & -- \\
\hline Bisphenol A & $80-05-7$ & $87 / 87$ & 4.7 & 9.2 & $.67 \mathrm{E}$ & $.44 \mathrm{E}$ & 400 & -- & -- \\
\hline $\begin{array}{l}\text { 5-Methyl-1H-benzotri- } \\
\text { azole }\end{array}$ & $136-85-6$ & $96 / 96$ & 2.1 & ND & $.079 \mathrm{E}$ & ND & -- & -- & -- \\
\hline \multicolumn{10}{|c|}{ Organic synthesis compounds } \\
\hline Anthraquinone & $84-65-1$ & $96 / 96$ & 7.3 & 5.2 & $0.14 \mathrm{E}$ & $0.10 \mathrm{E}$ & -- & -- & -- \\
\hline Carbazole $^{4}$ & $86-74-8$ & $96 / 96$ & 4.2 & 4.2 & $.021 \mathrm{E}$ & $.009 \mathrm{E}$ & -- & -- & -- \\
\hline Chloromethane & $74-87-3$ & $95 / 94$ & 2.1 & 11 & $.029 \mathrm{E}$ & $.055 \mathrm{E}$ & 30 & -- & -- \\
\hline \multicolumn{10}{|c|}{ Pavement- and combustion-derived compounds } \\
\hline Fluoranthene $^{4}$ & $206-44-0$ & $96 / 96$ & 9.4 & 6.3 & $0.031 \mathrm{E}$ & $0.026 \mathrm{E}$ & 300 & -- & -- \\
\hline Pyrene $^{4}$ & $129-00-0$ & $96 / 96$ & 7.3 & 4.2 & $.017 \mathrm{E}$ & $.028 \mathrm{E}$ & 200 & -- & -- \\
\hline Phenanthrene & $85-01-8$ & $96 / 96$ & 1.0 & 3.1 & $.006 \mathrm{E}$ & $.063 \mathrm{E}$ & -- & -- & -- \\
\hline Anthracene & $120-12-7$ & $96 / 96$ & 1.0 & ND & $.004 \mathrm{E}$ & ND & 2,000 & -- & -- \\
\hline Benzo[a]pyrene & $50-32-8$ & $96 / 96$ & ND & 1.0 & ND & $.26 \mathrm{E}$ & .2 & -- & $1(1)$ \\
\hline
\end{tabular}

ND 
Appendix 2. Summary statistics and human-health benchmarks for anthropogenic organic compounds detected in source- and finished-water samples collected during the second phase of sampling, June 2004-August 2005. —Continued

[Compounds within each primary-use category are listed in order from highest to lowest source-water detection frequency. Human-health benchmarks in bold are Maximum Contaminant Levels. CASRM, Chemical Abstracts Service Registry Number; E, estimated; AHTN, acetyl hexamethyl tetrahydronaphthalene; HHCB, hexahydrohexamethylcyclopentabenzopyran; MCPA, 2-methyl-4-chlorophenoxyacetic acid; $\mu \mathrm{g} / \mathrm{L}$, micrograms per liter; SW, source water; FW, finished water; $\mathrm{BQ}$, benchmark quotient; <, less than; >, greater than; ND, not detected; --, none]

\begin{tabular}{|c|c|c|c|c|c|c|c|c|c|}
\hline \multirow[t]{2}{*}{ Compound } & \multirow[t]{2}{*}{ CASRN ${ }^{1}$} & \multirow[t]{2}{*}{$\begin{array}{l}\text { Number of } \\
\text { samples } \\
\text { SW/FW }\end{array}$} & \multicolumn{2}{|c|}{$\begin{array}{l}\text { Detection frequency } \\
\text { (percent) }\end{array}$} & \multicolumn{2}{|c|}{$\begin{array}{l}\text { Maximum concentration } \\
(\mu \mathrm{g} / \mathrm{L})\end{array}$} & \multirow[t]{2}{*}{$\begin{array}{l}\text { Human-health } \\
\text { benchmark }^{2}\end{array}$} & \multicolumn{2}{|c|}{$\begin{array}{c}\text { Number of concentrations with } \\
\text { BO }>0.1 \text {; } \\
\text { (1) number of concentrations with } \\
\text { BO }>1\end{array}$} \\
\hline & & & Source water & Finished water & Source water & Finished water & & Source water & Finished water \\
\hline \multicolumn{10}{|c|}{ Personal-care and domestic use products } \\
\hline $\mathrm{HHCB}^{4}$ & $1222-05-5$ & $96 / 96$ & 64 & 54 & $0.21 \mathrm{E}$ & $0.30 \mathrm{E}$ & -- & -- & -- \\
\hline Caffeine & $58-08-2$ & $77 / 74$ & 61 & 58 & .58 & .22 & -- & -- & -- \\
\hline $\mathrm{AHTN}^{4}$ & $21145-77-7$ & $96 / 96$ & 27 & 18 & $.1 \mathrm{E}$ & $.30 \mathrm{E}$ & -- & -- & -- \\
\hline Camphor ${ }^{4}$ & $76-22-2$ & $96 / 96$ & 25 & 9.4 & $.021 \mathrm{E}$ & $.021 \mathrm{E}$ & -- & -- & -- \\
\hline $\begin{array}{l}\text { Triethyl citrate (ethyl } \\
\text { citrate) }\end{array}$ & $77-93-0$ & $96 / 96$ & 16 & 17 & $.072 \mathrm{E}$ & $.036 \mathrm{E}$ & -- & -- & -- \\
\hline $\begin{array}{l}\text { Nonylphenol diethoxy- } \\
\text { late (total) }\end{array}$ & $26027-38-2$ & $96 / 96$ & 9.4 & 11 & $4.3 \mathrm{E}$ & $5.9 \mathrm{E}$ & -- & -- & -- \\
\hline Triclosan & $3380-34-5$ & $96 / 96$ & 5.2 & 3.1 & $.098 \mathrm{E}$ & $.050 \mathrm{E}$ & -- & -- & -- \\
\hline Cotinine & $486-56-6$ & $96 / 96$ & 4.2 & 4.2 & $.28 \mathrm{E}$ & $.077 \mathrm{E}$ & -- & -- & -- \\
\hline Menthol & $89-78-1$ & $96 / 96$ & 4.2 & 5.2 & $.049 \mathrm{E}$ & $.080 \mathrm{E}$ & -- & -- & -- \\
\hline $\begin{array}{l}\text { Octylphenol monoethox- } \\
\text { ylate (total) }\end{array}$ & -- & $96 / 96$ & 4.2 & 2.1 & $.75 \mathrm{E}$ & $.70 \mathrm{E}$ & -- & -- & -- \\
\hline Indole & $120-72-9$ & $96 / 96$ & 3.1 & 1.0 & $.011 \mathrm{E}$ & $.003 \mathrm{E}$ & -- & -- & -- \\
\hline $\begin{array}{l}\text { Octylphenol diethoxy- } \\
\text { late (total) }(\mathrm{OP} 2 \mathrm{EO})^{4}\end{array}$ & $26636-32-8$ & $96 / 96$ & 2.1 & 4.2 & $.1 \mathrm{E}$ & $.24 \mathrm{E}$ & -- & -- & -- \\
\hline$d$-Limonene ${ }^{4}$ & $5989-27-5$ & $96 / 96$ & 1.0 & 2.1 & $.044 \mathrm{E}$ & $.075 \mathrm{E}$ & -- & -- & -- \\
\hline 4- $n$-Octylphenol & $1806-26-4$ & $96 / 96$ & ND & 1.0 & ND & $.25 \mathrm{E}$ & -- & -- & -- \\
\hline 4-tert-Octylphenol ${ }^{4}$ & $140-66-9$ & $96 / 96$ & ND & 2.1 & ND & $.016 \mathrm{E}$ & -- & -- & -- \\
\hline Acetophenone & $98-86-2$ & $96 / 96$ & ND & ND & ND & ND & 700 & -- & -- \\
\hline \multicolumn{10}{|c|}{ Plant- or animal-derived biochemicals } \\
\hline Cholesterol & $57-88-5$ & $96 / 96$ & 24 & 10 & $1.6 \mathrm{E}$ & $1.3 \mathrm{E}$ & -- & -- & -- \\
\hline 3-beta-Coprostanol ${ }^{4}$ & $360-68-9$ & $96 / 96$ & 13 & 6.3 & $1.4 \mathrm{E}$ & $.99 \mathrm{E}$ & -- & -- & -- \\
\hline beta-Stigmastanol & $19466-47-8$ & $96 / 96$ & 9.4 & 5.2 & $1.6 \mathrm{E}$ & $1.6 \mathrm{E}$ & -- & -- & -- \\
\hline $\begin{array}{l}\text { 3-Methyl-1(H)-indole } \\
\text { (Skatole) }\end{array}$ & $83-34-1$ & $96 / 96$ & 4.2 & ND & $.009 \mathrm{E}$ & ND & -- & -- & -- \\
\hline beta-Sitosterol & $83-46-5$ & $96 / 96$ & 2.1 & 4.2 & $1.4 \mathrm{E}$ & $1.0 \mathrm{E}$ & -- & -- & -- \\
\hline
\end{tabular}


Appendix 2. Summary statistics and human-health benchmarks for anthropogenic organic compounds detected in source- and finished-water samples collected during the second phase of sampling, June 2004-August 2005. - Continued

[Compounds within each primary-use category are listed in order from highest to lowest source-water detection frequency. Human-health benchmarks in bold are Maximum Contaminant Levels. CASRM, Chemical Abstracts Service Registry Number; E, estimated; AHTN, acetyl hexamethyl tetrahydronaphthalene; HHCB, hexahydrohexamethylcyclopentabenzopyran; MCPA, 2-methyl-4-chlorophenoxyacetic acid; $\mu \mathrm{g} / \mathrm{L}$, micrograms per liter; SW, source water; FW, finished water; BQ, benchmark quotient; <, less than; >, greater than; ND, not detected; --, none]

\begin{tabular}{|c|c|c|c|c|c|c|c|c|c|}
\hline \multirow[t]{2}{*}{ Compound } & \multirow[t]{2}{*}{ CASRN ${ }^{1}$} & \multirow[t]{2}{*}{$\begin{array}{l}\text { Number of } \\
\text { samples } \\
\text { SW/FW }\end{array}$} & \multicolumn{2}{|c|}{$\begin{array}{l}\text { Detection frequency } \\
\text { (percent) }\end{array}$} & \multicolumn{2}{|c|}{$\begin{array}{l}\text { Maximum concentration } \\
(\mu \mathrm{g} / \mathrm{L})\end{array}$} & \multirow[t]{2}{*}{$\begin{array}{l}\text { Human-health } \\
\text { benchmark }^{2}\end{array}$} & \multicolumn{2}{|c|}{$\begin{array}{l}\text { Number of concentrations with } \\
\text { B0 }>0.1 \text {; } \\
\text { (1) number of concentrations with } \\
\text { B0 }>1\end{array}$} \\
\hline & & & Source water & Finished water & Source water & Finished water & & Source water & Finished water \\
\hline \multicolumn{10}{|c|}{ Refrigerants and propellants } \\
\hline $\begin{array}{l}\text { Trichlorofluoromethane } \\
\text { (CFC-11) }\end{array}$ & $75-69-4$ & $95 / 94$ & 1.1 & ND & $0.020 \mathrm{E}$ & ND & 2,000 & -- & -- \\
\hline \multicolumn{10}{|c|}{ Solvents } \\
\hline cis-1,2-Dichloroethene & $156-59-2$ & $95 / 94$ & 15 & 14 & 0.59 & 0.32 & 70 & -- & -- \\
\hline Perchloroethene ( PCE) & $127-18-4$ & $95 / 94$ & 15 & 13 & .11 & $.053 \mathrm{E}$ & 5 & -- & -- \\
\hline$p$-Cresol & $106-44-5$ & $96 / 96$ & 15 & 6.3 & $.075 \mathrm{E}$ & $.10 \mathrm{E}$ & -- & -- & -- \\
\hline Trichloroethene (TCE) & $79-01-6$ & $95 / 94$ & 8.4 & 6.4 & $.061 \mathrm{E}$ & $.031 \mathrm{E}$ & 5 & -- & -- \\
\hline $\begin{array}{l}\text { Methylene chloride } \\
\text { (dichloromethane) }^{4}\end{array}$ & $75-09-2$ & $95 / 94$ & 2.1 & 17 & .33 & .38 & 5 & -- & -- \\
\hline$n$-Propylbenzene & $103-65-1$ & $95 / 94$ & 2.1 & ND & $.021 \mathrm{E}$ & ND & -- & -- & -- \\
\hline Acetone & $67-64-1$ & $95 / 94$ & 1.1 & 14 & $3.7 \mathrm{E}$ & 11.2 & 6,000 & -- & -- \\
\hline 1,2-Dichloroethane & $107-06-2$ & $95 / 94$ & ND & 6.4 & ND & .31 & 5 & -- & -- \\
\hline $\begin{array}{l}\text { Carbon tetrachloride } \\
\text { (tetrachloromethane) }\end{array}$ & $56-23-5$ & $95 / 94$ & ND & 32 & ND & .36 & 5 & -- & -- \\
\hline Hexachloroethane & $67-72-1$ & $95 / 94$ & ND & 1.1 & ND & $.027 \mathrm{E}$ & .7 & -- & -- \\
\hline $\begin{array}{l}\text { Methyl ethyl ketone } \\
\text { (MEK) }\end{array}$ & $78-93-3$ & $95 / 94$ & ND & 8.5 & ND & 4.1 & 4,000 & -- & -- \\
\hline Tetrahydrofuran & 109-99-9 & $95 / 94$ & ND & 1.1 & ND & $.70 \mathrm{E}$ & -- & -- & -- \\
\hline
\end{tabular}



Publishing support provided by:

Helena Publishing Service Center

For more information concerning this publication, contact:

Director, USGS South Dakota Water Science Center

1608 Mt. View Rd.

Rapid City, SD 57702

(605) 394-3200

http://sd.water.usgs.gov

Information regarding the National Water-Quality Program is available at http://water.usgs.gov/nawqa/ 



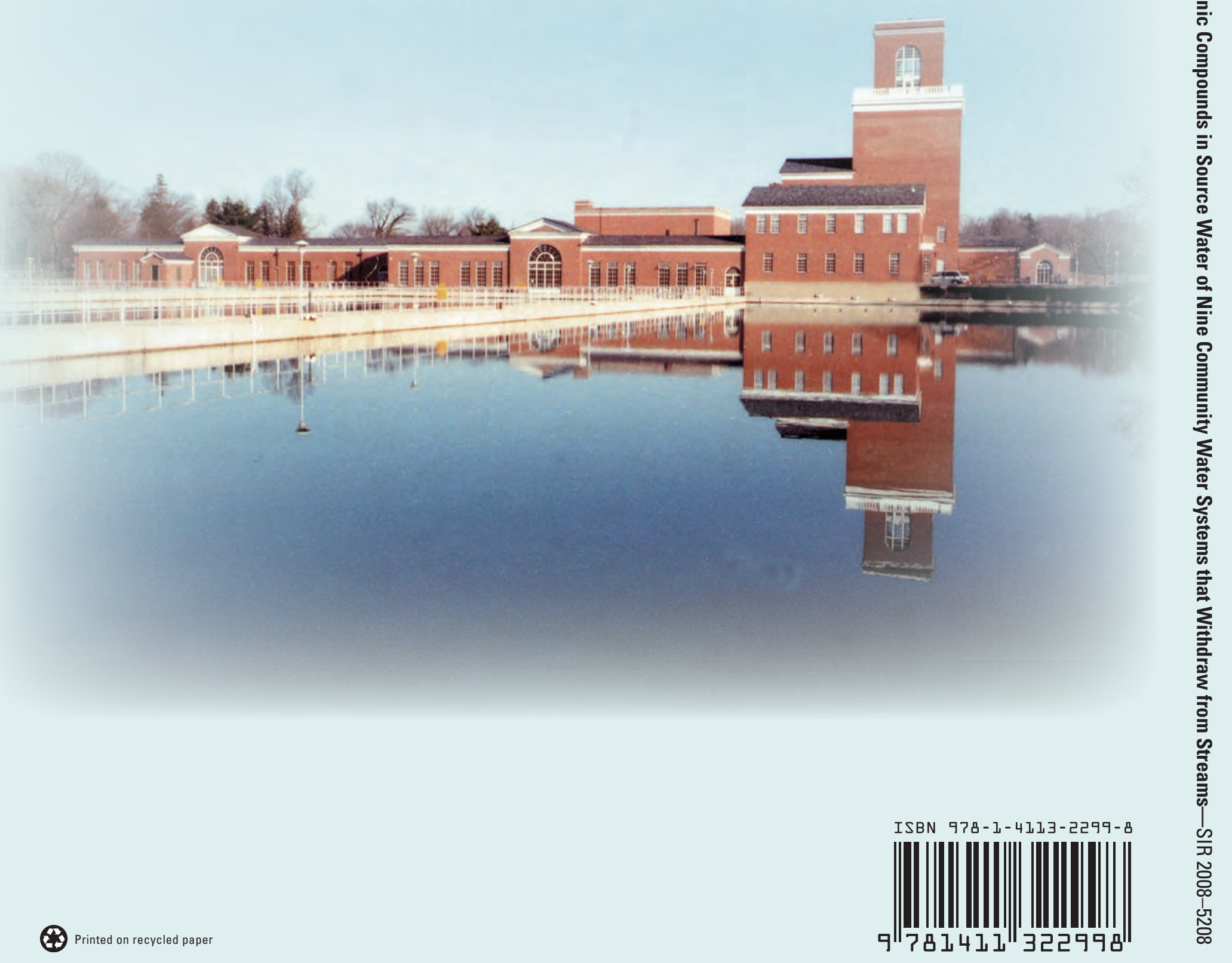

